\title{
Kawah Ijen volcanic activity: a review
}

\author{
Corentin Caudron · Devy Kamil Syahbana • \\ Thomas Lecocq • Vincent Van Hinsberg • \\ Wendy McCausland • Antoine Triantafyllou • \\ Thierry Camelbeeck • Alain Bernard · Surono
}

Received: 30 June 2014 / Accepted: 16 November 2014 / Published online: 7 February 2015

(C) The Author(s) 2015. This article is published with open access at Springerlink.com

\begin{abstract}
Kawah Ijen is a composite volcano located at the easternmost part of Java island in Indonesia and hosts the largest natural acidic lake in the world. We have gathered all available historical reports on Kawah Ijen's activity since 1770 with the purpose of reviewing the temporal evolution of its activity. Most of these observations and studies have been conducted from a geochemical perspective and in punctuated scientific campaigns. Starting in 1991, the seismic activity and a set of volcanic lake parameters began to be weekly available. We present a database of those measurements that, combined with historical reports, allow us to review each eruption/unrest that occurred during the last two centuries. As of 2010, the volcanic activity is monitored by a new multi-disciplinary network, including digital seismic stations, and lake level and temperature measurements. This detailed monitoring provides an opportunity for better
\end{abstract}

Editorial responsibility: G. Giordano

C. Caudron $(\bowtie) \cdot$ D. K. Syahbana - T. Lecocq · T. Camelbeeck Royal Observatory of Belgium, Seismology Section, 3 avenue Circulaire, 1180 Uccle, Belgium

e-mail: CCaudron@ntu.edu.sg

C. Caudron

Earth Observatory of Singapore, Nanyang Technological

University, 50 Nanyang Avenue, Block N2-01a-15,

Singapore, 639798, Singapore

C. Caudron - D. K. Syahbana - A. Bernard

Department of Earth and Environmental Sciences, Université Libre de Bruxelles, 50 Avenue Franklin

Roosevelt, 1050 Brussels, Belgium

D. K. Syahbana $\cdot$ Surono

Centre for Volcanology and Geological Hazard Mitigation, Geological Agency, Ministry of Energy and Mineral Resources, Jalan Diponegoro 57, Bandung 40122, Indonesia classifying seismic events and forecasting volcanic unrest at Kawah Ijen, but only with the understanding of the characteristics of this volcanic system gained from the historical review presented here.

Keywords Review · Monitoring · Hyperacidic lake · Historical activity $\cdot$ Hydrothermal system

\section{Introduction}

Kawah Ijen (2386 m) is a composite volcano located within the Pleistocene Ijen Caldera, at the easternmost part of Java island, in Indonesia (Fig. 1). The visible superficial manifestations of the hydrothermal system of Kawah Ijen's activity consist of the world's largest hyperacidic lake on Earth
D. K. Syahbana

Helmholtz Centre GFZ German Research Centre for Geosciences, Telegrafenberg, 1447313 Potsdam, Germany

V. Van Hinsberg

Department of Earth and Planetary Sciences, McGill,

3450 University St., Montreal, Quebec H3A 2A7, Canada

W. McCausland

U.S. Geological Survey, Cascades Volcano Observatory,

1300 SE Cardinal Ct. 100, Vancouver, WA 98683, USA

A. Triantafyllou

Department of Fundamental and Applied Geology,

Université de Mons, rue de Houdain, 9,

7000 Mons, Belgium 


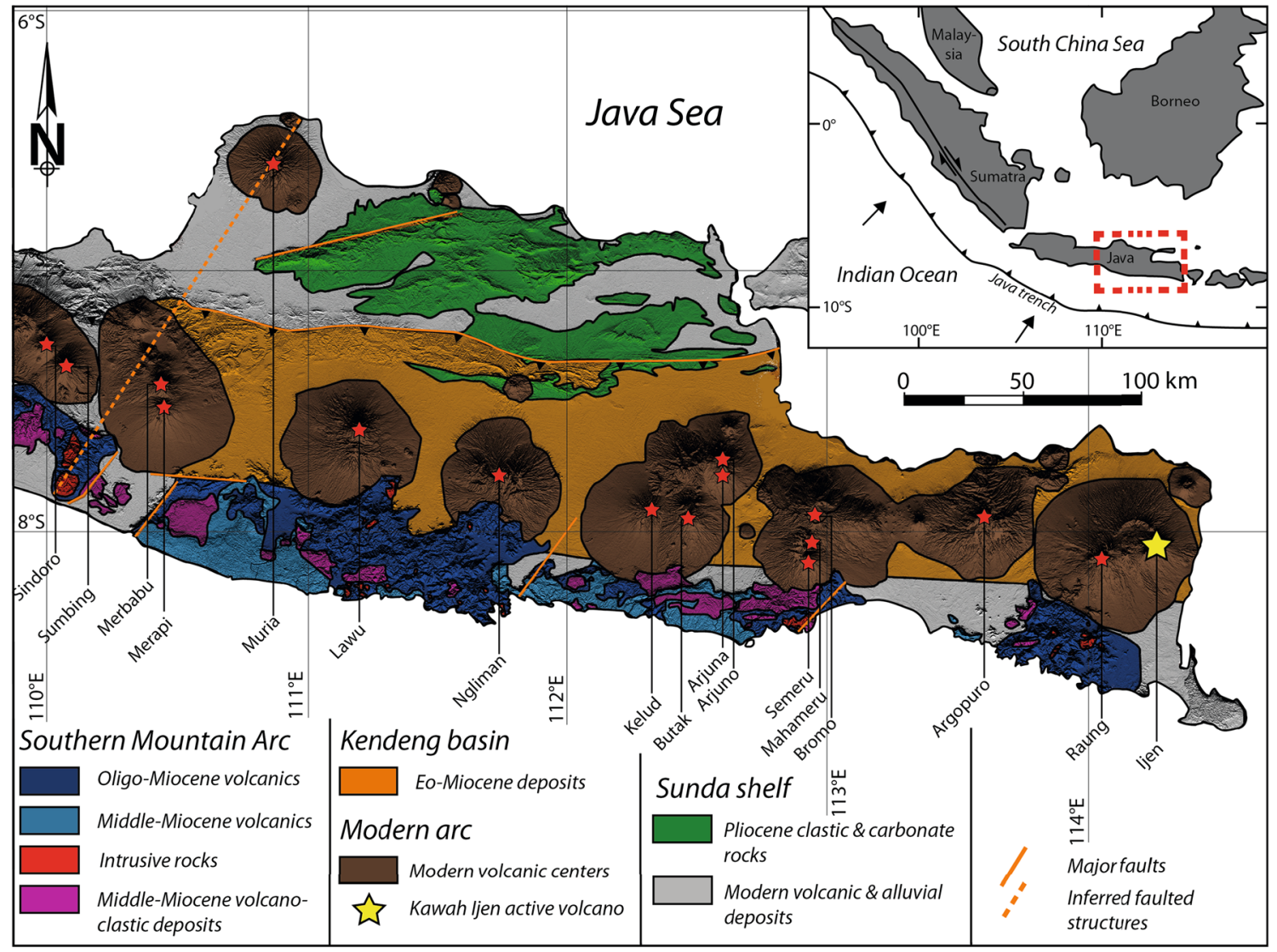

Fig. 1 Location of Kawah Ijen and tectonic settings of Java island (after Smyth et al. (2005) and Clements et al. (2009))

$\left(V=27 * 10^{6} \mathrm{~m}^{3}, T>30{ }^{\circ} \mathrm{C}, \mathrm{pH}<0.3\right)$, a few thermal discharges and crater fumaroles (Delmelle et al. 2000) which produce significant amounts of native sulfur. Specific dynamics and seismicity are triggered by the hydrothermal activity. The most recent magmatic eruption of the volcano took place in 1817, but frequent phreatic and geyser-like activity have occurred since that time (Global Volcanism Program: http://www.volcano.si.edu).

Knowledge of a volcano's historical activity is a key aspect to understand a volcano, but also to identify precursors of an eruption and thus enable hazard monitoring. Unfortunately, the historical records for Kawah Ijen are patchy, at best. Many of the reports and seismograms have been lost or disseminated over Indonesia. Despite these frustrating losses, more than a thousand documents were recovered in the library of the Center for Volcanology and Geological Hazard Mitigation (CVGHM) in Bandung and at Kawah Ijen observatory, including technical reports, newspapers, and scientific publications. These archives contain extensive information on the volcanic hydrothermal activity over the last approximately 200 years. We compare these with the reference online database (Global Volcanism Program: http://www.volcano.si.edu). The information gathered here complements or corrects the one reported on the website to each unrest/eruptive event. The first objective of this study is to summarize the information provided in different language reports (i.e., Dutch, English, French, German, and Indonesian) into a single document in English. The second objective is to gather into a historical database the scientific observations available since the volcano became continuously monitored. The unrest will be described with respect to the variables that were monitored and the database made available through WOVOdat (http://www.wovodat.org/). The alert level scheme used corresponds to the one established by CVGHM. The last part of this study will present an overview of the background activity as observed during the last years by installing a new seismic network and immersing diver into the highly acidic lake waters. These instruments significantly improve our knowledge of the volcanic background activity and, when complemented by the historical database, provide a baseline to interpret future unrest/eruptions. 


\section{Volcanic settings}

Ijen caldera complex

The Ijen caldera complex measures approximately $210 \mathrm{~km}^{2}$ $(18 \mathrm{~km} \times 15 \mathrm{~km}$, respectively E-W and N-S sections, Fig. 2). Its name is linked to that of the only currently active volcano within the caldera, Kawah Ijen. Gunung Raung (Fig. 2), a large stratovolcano on the western flank of the Ijen caldera is usually considered not to be part of the caldera complex. The caldera contains more than 15 post caldera volcanic cones (Fig. 2). It is bounded to the north by the crescent-shaped Kendeng caldera collapse remnant wall (named Old Ijen caldera rim in Fig. 2) and to the south by the post-caldera rim volcanoes Merapi, Ranteh, and Jampit (Kemmerling 1921). The main hydrological features in the caldera are the Banyu Pahit acidic river which originates from the Kawah Ijen crater lake, and the neutral Kali Sat and Kali Senggon rivers draining the western and eastern parts of the caldera, respectively. All rivers combine in the north and leave the caldera through a canyon in the Kendeng caldera rim (Fig. 2).
The Ijen caldera complex formed during the Pleistocene as a large stratovolcano. Caldera formation is not well constrained but occurred between 300,000 (youngest dated pre-caldera deposit) and 50,000 (oldest dated postcaldera deposit) years ago (Sitorus 1990) through the collapse of this Old Ijen stratovolcano (Kemmerling 1921; Sitorus 1990). A non-volcanic structure then developed inside the caldera (van Bemmelen 1941), as a lake, which emptied $\sim 50,000$ years ago owing to the fault systems that cut the northern Kendeng caldera wall (Sundhoro (1990) in (Pengembangan 2002), (Kemmerling 1921)) (Fig. 2). The post-caldera volcanic centers comprise many separate vents (Fig. 2). They are distributed in the southern part of the caldera and are further divided on the basis of their geographical position within the complex (blue in Fig. 2). The six caldera rim volcanoes (yellow in Fig. 2), are dominantly composite cones: Ringghi, Jampit, Ranteh, Pawenen, Merapi, and possibly Suket (Kemmerling 1921). Around 25,000 years ago, 13 intracaldera cinder cones extending E-W from Mlaten to Kawah Ijen were active (Sitorus 1990; Berlo 2001; Van Hinsberg et al. 2010b). This trend is aligned to the tectonic lineament identified by

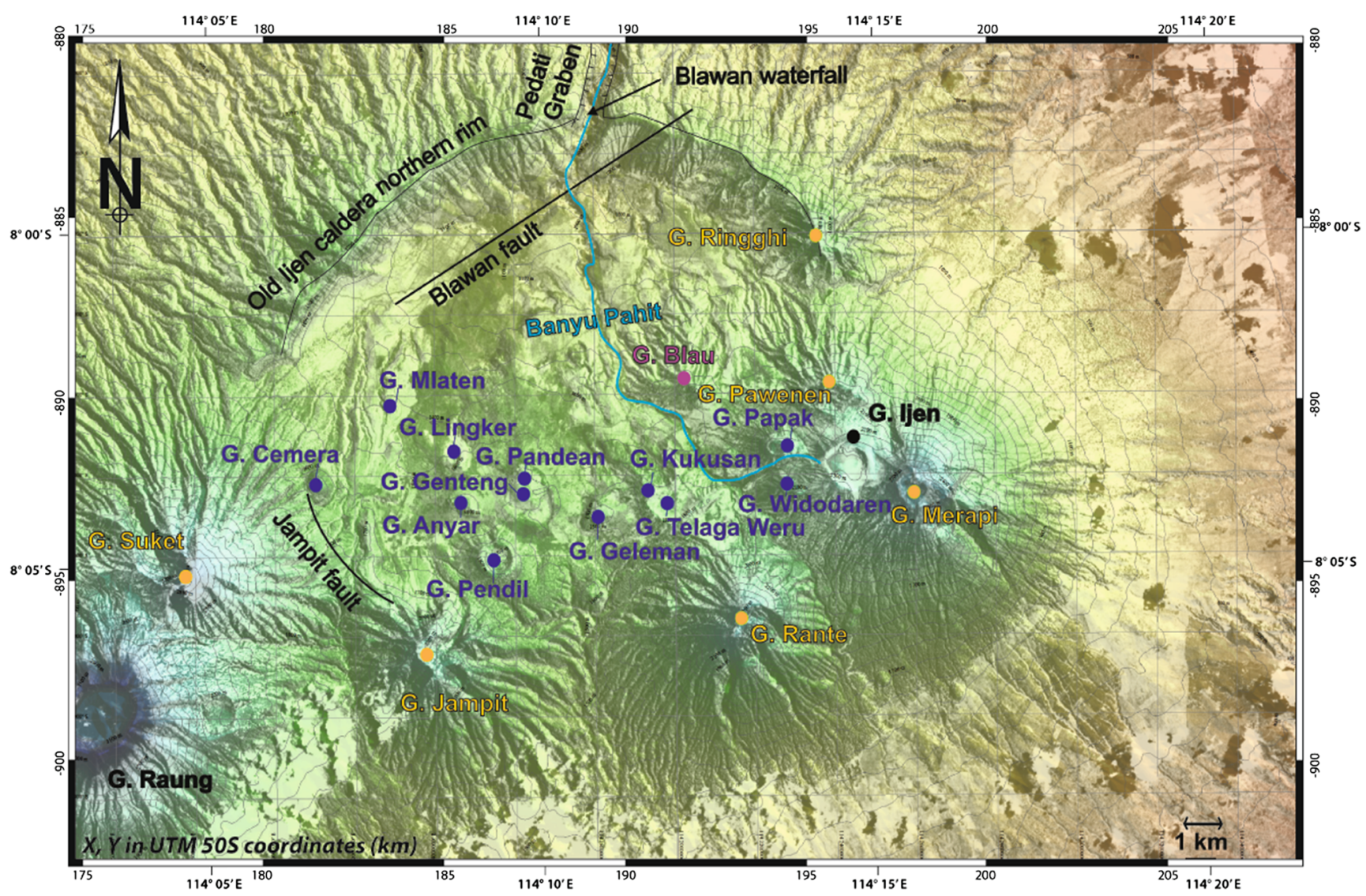

Fig. 2 Ijen caldera past and active volcanic edifices and faultings. The map is derived from a Landsat7 image (7th band greyscale) overlaid by the colored Aster global digital elevation map (GDEM) product.
Shuttle radar topography mission (SRTM) product was used to draw the contour lines. See text for details 
Carn (1999). Whereas the caldera rim volcanoes erupted high-Ca magmas of basalt to basaltic-andesite composition, the intracaldera volcanoes erupted low-Ca magmas of basaltic-andesite to dacite composition. Their distinct position along with a distinct fractionation trends in Ca suggest spatial variation in chemistry within the volcanic complex that might be linked to sub-volcanic structure or different reservoirs depths (Handley et al. 2007).

\section{Kawah Ijen setting}

Kawah Ijen is a basalt to dacitic composite volcano that sits on the flank of the Merapi rim-volcano and forms the easternmost member of the intra-caldera volcano series (Van Hinsberg et al. 2010b). Kawah Ijen volcano is the only volcanic cone currently showing signs of activity. Kawah Ijen's unique structural position is also borne out by its compositions, given that it has erupted both high-Ca and low-Ca magmas (Berlo 2001; Handley et al. 2007; Van Hinsberg et al. 2010a). This indicates that Kawah Ijen is tapping both the rim-volcano reservoir and intracaldera reservoir. There is no evidence for physical mixing and migling (Berlo 2001). This implies separate magma pathways for magmas erupted from these different reservoirs.

The formation of the present-day Kawah Ijen structure was controlled by several events: its formation on the flank of Merapi volcano, resulting in the partial destruction of Merapi's cone (Junghuhn 1853), a cone building period (Kemmerling 1921; Sitorus 1990; Van Hinsberg et al. 2010a), and a destructive period inferred from hydrothermal, phreatic, and phreato-magmatic deposits cutting into progressively lower stratigraphic levels of the cone-building stage (Van Hinsberg et al. 2010a). This last period when the breach in the western crater rim developed acted as the outflow channel for the crater lake during parts of the volcano's history. The depression that developed in the crater as a result of the destructive phase allowed for the accumulation of meteoric water and thus the formation of a lake (Hengeveld 1920). The destructive phase of activity was not limited to phreatic and phreatomagmatic eruptions, but includes extrusion of at least three lava flows that flow towards the west and through the Banyu Pahit river valley (Kemmerling 1921; Sitorus 1990). These are interbedded with phreatic and phreato-magmatic deposits in exposures in the upper Banyu Pahit river valley (Van Hinsberg et al. 2010a).

The magmatic-hydrothermal system of Kawah Ijen is extremely active and appears on the surface as actively degassing fumaroles, a large hyperacidic volcanic lake, and an acidic river discharged on the western flanks.

On the SE flank, adjacent to the lake, there is a small dome measuring approximately $100 \mathrm{~m}$ in diameter and $20 \mathrm{~m}$ in height, which is the locus of strong fumarolic activity
(Fig. 3). This area was exposed as a result of a large phreatomagmatic eruption that took place in 1817 (Junghuhn 1853; Bosch 1858). The white to yellow fumes reach temperatures up to $600{ }^{\circ} \mathrm{C}$ (Van Hinsberg et al. 2009). A complete description of the fumarolic field is given by Van Hinsberg et al. (2010b). Although the onset of lake development and hyper acidification is unknown, historic reports of its existence were made in 1789 (Oudgast 1820), and the lake was described in detail by Leschenault (de la Tour) (1858) who visited the lake in 1805 . Kawah Ijen's volcanic lake is currently the largest natural acidic lake in the world and is characterized by an oxidized hyperacidic brine with $>100 \mathrm{~g} \mathrm{~kg}^{-1}$ of dissolved solids (Delmelle et al. 2000; Van Hinsberg et al. 2010b). pH values of the lake during the last 50 years have been consistently low $(\mathrm{pH}=0-0.4)$. The first detailed geochemical compositions of the lake were published by Delmelle and Bernard (1994) and Delmelle et al. (2000), although qualitative data on composition go back to 1805 (Leschenault (de la Tour) 1858). According to Takano et al. (2004), the lake is chemically homogeneous in the water column excepting near the lake bottom. The lake generally has a green color with floating yellow deposits of sulphur spherules at the surface (Delmelle and Bernard 1994). Chemical modeling indicates the occurrence of molten sulphur at the lake bottom (Delmelle and Bernard 1994). The Banyu Pahit river emerges on the western flank of the edifice (Fig. 3). The river composition, its spatial evolution, and alteration have been studied in detail (Delmelle and Bernard 2000; Palmer et al. 2011; Van Hinsberg et al. 2010a).

\section{Summary of the observations for the period 1789-1991}

Historical data on Kawah Ijen and the Ijen volcanic complex are intimately linked to the colonial history of this part of Java. The Dutch occupied easternmost Java in 1770 (Leschenault (de la Tour) 1858) and established a fort at Banyuwangi (22 km to the South East of Kawah Ijen). The interior of the Ijen caldera and Kawah Ijen volcano were visited by the fort's commander in 1789 (Oudgast 1820), although native sulphur originating from Kawah Ijen had already been used for gunpowder manufacture from 1786 (Bosch 1858). Following the transition to French rule, Ijen was visited by Leschenault (de la Tour) in 1805, who provided a detailed report on Kawah Ijen (Leschenault (de la Tour) 1858). This is a key report because it is the only scientific report that described the crater lake prior to its 1817 eruption. The 1817 eruption attracted a large number of researchers to Kawah Ijen, and it was discussed in detail by Junghuhn (1853) and Bosch (1858). From the 1850s until the independence of Indonesia, the Ijen system was regularly visited by scientists and engineers commonly 


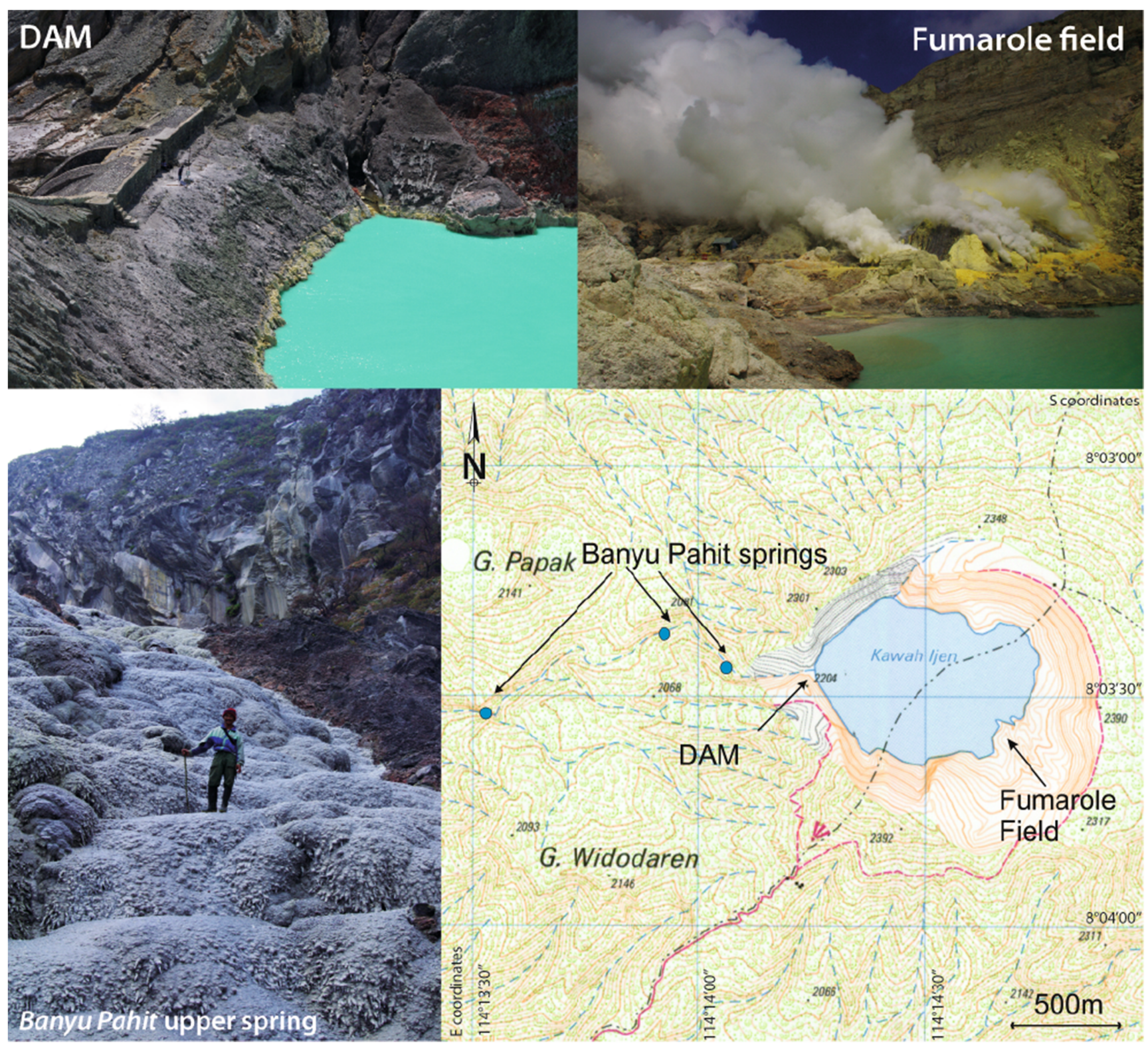

Fig. 3 Kawah Ijen crater features (topographical map (1:25,000))

on the initiative of the Dutch colonial government resulting in a large number of technical reports, and culminating in a monograph series on Ijen in 1920 (Braak 1920; Kemmerling 1921; Woudstra 1920). Monitoring also started in this period, especially after increased activity in 1917. For some periods, daily monitoring data were available. Indonesian reports represent the main data source after independence together with a UN study in the late 1950s (Mueller 1957a, b). Data up to 1991 were limited, but since then, a number of detailed studies and monitoring efforts have provided a wealth of data.
The review of the historical documents has been subdivided into four sections; each corresponding to specific monitoring aspects.

Temperature, level and general observations

\section{Eighteenth-nineteenth century}

Prior to 1817 , Leschenault de la Tour explored the Ijen caldera and Kawah Ijen crater in 1805 (Leschenault (de la Tour) 1858). At this time, the area was sparsely populated and no permanent settlements were present within the 
caldera. Dense forest covered the outer slopes of the caldera, whereas the inner plateau was covered by long grass and isolated trees, as it is now. Kawah Ijen's outer flanks were covered in vegetation up to the crater rim and ferns were found on its inner flanks. The crater rim was connected to Merapi volcano by a plateau bordered by a steep scarp in Merapi's flank.

Leschenault de la Tour estimated Kawah Ijen's crater to be 1000 by $800 \mathrm{~m}$, and 130-m deep (assuming conversion factors of 1 toise $=1.95 \mathrm{~m}$, and 1 pied $=325 \mathrm{~mm}$ ). A warm, greenish-white lake that emitted fumes filled approximately half of the crater, whereas a plateau with fumaroles occupied the other end at ca. 8 to $10 \mathrm{~m}$ above lake level (Fig. 4). The fumaroles were encrusted in needles of native sulfur. According to his local guides, the fumaroles used to be located further north in 1803 and Leschenault de la Tour did indeed find remnants of these vents. There was no cliff between lake and fumarole plateau in 1803. Fumes were also emitted from fractures on the plateau, and puncturing its surface created new vents. The most active fumaroles were found on the southern edge of the plateau. These roar and appeared to be "on fire" at night, and threw out material that was hot and flattens upon impact. The first observation agreed with the present-day flaming fumaroles, and the material being thrown out was most likely liquid sulfur.

The surface of the plateau was covered by a chaotic arrangement of white altered rocks, black teardrop-shaped glass, lava fragments, sulfur, and alum. All these components are currently found in samples from the active fumarole mount (cf. Van Hinsberg et al. (2010a)). A steep cliff bounded the crater in the north, whereas slopes were more gradual elsewhere, and it was possible to descend to
Fig. 4 Comparison of the Kawah Ijen crater lake in 1805 (from Leschenault (de la Tour) (1858)), and the present-day. The main differences are an increase in the size of the lake, a steepening of the eastern crater rim, and the presence of direct lake outflow in 1805 . The bottom map also shows the locations of the three craters identified by Kemmerling (1921) in the summit area
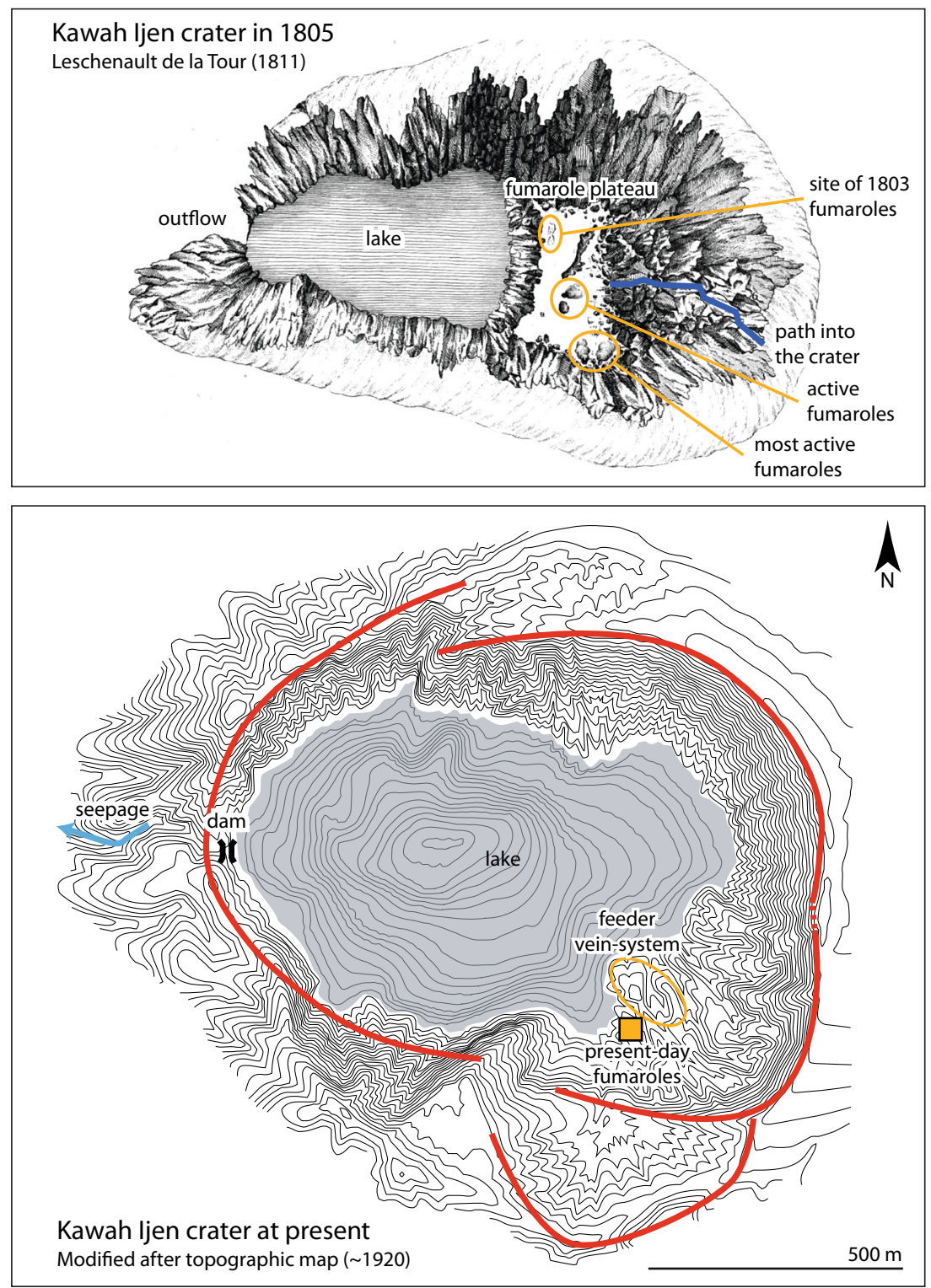
the fumarole plateau using ladders in the southeast (Fig. 4). An outflow of lake waters was present in the southwest through a gap in the crater rim. This outflow formed the acid Banyu Pahit river. Leschenault (de la Tour) showed that it combines with the neutral Kali Sat river close to present-day Blawan village into the Banyu Putih (White River) before passing through the Ijen caldera rim onto the outer flanks of the Ijen complex and the Asambagus plain. He claimed that during dry periods, the acid river disappeared in its sandy bed, thereby not contaminating the neutral Kali Sat waters and resulting in potable river water on the Asambagus plain. In contrast, during heavy rain, the rivers mixed, and the resulting waters were acidic and unusable. Horsfield (1816) reported the same for 1806 . This observation differs from the present-day situation where both rivers always mix, and heavy rains dilute the acidity of the Banyu Putih. This led Junghuhn to discredit Leschenault de la Tour's observations and explanation (Junghuhn 1853). However, when Junghuhn visited in 1844, and at the present-day, the Banyu Pahit river was fed from seepage, rather than surface outflow, and thus likely less responsive to rain. For surface outflow, heavy rain would have raised the lake level and thus have increased outflow of acidic waters and have led to a more acidic Banyu Putih river, especially if the Banyu Pahit did not mix with the Kali Sat during dry spells. In fact, raininduced level variations necessitated the construction of a dam to regulate acidic input into the Banyu Putih during the early twentieth century, when direct outflow was also present.

Surface outflow from the lake in the late 1700s and 1800 s is supported by observations reported by "Oudgast" (i.e., anonymous, 1820) for visits made in 1789 and 1790. Although "Oudgast" did not provide many additional data on the Ijen system, his observations were consistent with those of Leschenault de la Tour. He descended to the lake by rope in 1789 , and observed yellow sulfur floating on the lake, and emission of dense fumes by roaring fumaroles.

Later literature (e.g., Bosch 1858; Neumann van Padang 1983) reported an eruption of Kawah Ijen in 1796. This was based on a note on Horsfield's mineralogical map of Java published as an inset in Raffles' topographic map of Java (Raffles 1817). Although this note linked to "Tashem" volcano, its location on the map was interpreted as it referring to Ijen, despite Horsfield being well acquainted with the name "Ijen" (e.g., Horsfield 1814, 1816). Curiously, Horsfield did not mention an eruption of Ijen in his own writings nor is it mentioned by Leschenault de la Tour who visited only 9 years after this eruption. In fact, the identical observations by "Oudgast" in 1789-1790 and Leschenault de la Tour in 1805 would seem to preclude a significant event. Leschenault (de la Tour) (1858) did report a large landslide that traveled down from Merapi north of Banyuwangi to the sea in ca. 1792, but explicitly stated that this was not accompanied by any volcanic activity. Perhaps this event was mistakenly added as an eruption on Horsfield's map, or the eruption referred to a different volcano altogether. In any case, we conclude that there is no evidence that Kawah Ijen erupted in 1796.

1817 eruption The most recent significant eruption of Kawah Ijen occurred in Jan-Feb 1817. It was reported in detail in Junghuhn (1853) and Bosch (1858). Neither author witnessed the eruption directly and they instead based themselves on written reports and witness accounts. Figure 5 provides a day-to-day overview of the eruption. It commenced on Jan 16 with explosions, earthquakes, and the rise of an eruption column above the crater, which blocked out the sun (Junghuhn 1853; Bosch 1858). This continued to the 24th, at which point a column of fire was seen where the crater would be located, followed by ash in Banyuwangi from the 25 th. The ash was dense enough to turn day into night and to make trees and bamboo huts collapse under the weight. At the same time, cold mudflows laden with debris came down the outer flanks of the volcano, following the Banyu Putih valley north and flooding the Asambagus plain, and southeast to Banyuwangi flooding the plains south of it and destroying a complete forest in the process. Reinwardt (1858) further observed evidence in 1821 of a flow to the north-east, entering the sea south of the Baluran volcanic complex (30 km to the North East of Kawah Ijen). This third direction is in perfect agreement with predictions on the official hazard map for Ijen (see BGVN 2012).

The volcano subsequently calmed down, although it still emitted an eruption column, and light ash continued to fall in Banyuwangi. On Feb 10th, there was another large explosion followed by $\sim 3-4 \mathrm{~cm}$ of dry grey ash in Banyuwangi. Flooding and mudflows resumed in the following days linked to heavy rain. The sky cleared from the 11th and ashfall stopped, although thick "smoke" continued to rise from the crater up to the $18 \mathrm{th}$. Although there were further reports of activity as observed from Banyuwangi, a visitor to Kawah Ijen "6 days after the eruption" still reported "fire" and smoke from the crater (Bosch 1858). Throughout the eruption, there was also a strong smell of sulfur.

The impact of the eruption on easternmost Java was severe. There were no reports of human casualties directly related to the eruption. However, aside from loss of cattle and especially poultry, large areas of fertile low-lying farmland around Banyuwangi and in the Asambagus plain were covered in sulfur-bearing mud, which hardened into a solid crust, making them unusable for agriculture for several years. There was further a lack of potable water, and an outbreak of disease (Junghuhn 1853; Bosch 1858).

After 1817 Six days "after the eruption" (most likely the 22nd of February), a local resident was sent to investigate 
Fig. 5 Timeline of visits and reports on the Ijen caldera complex and Kawah Ijen in the eighteenth and nineteenth centuries. The inset lists the events during the 1817 eruption (Junghuhn 1853, Bosch 1858)

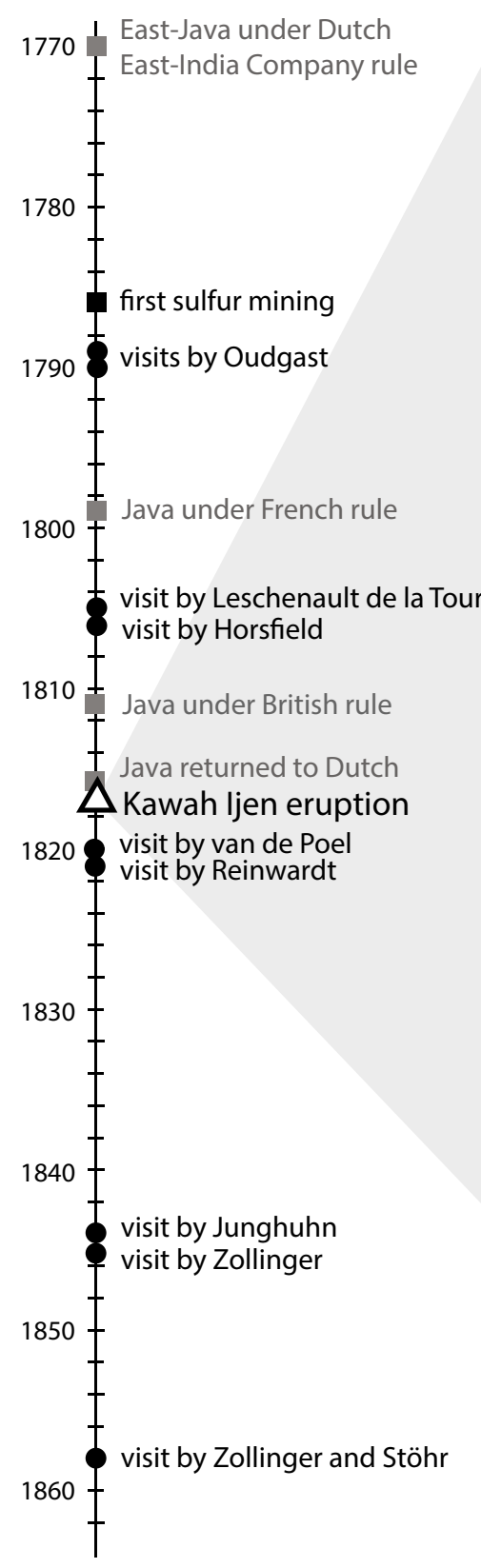

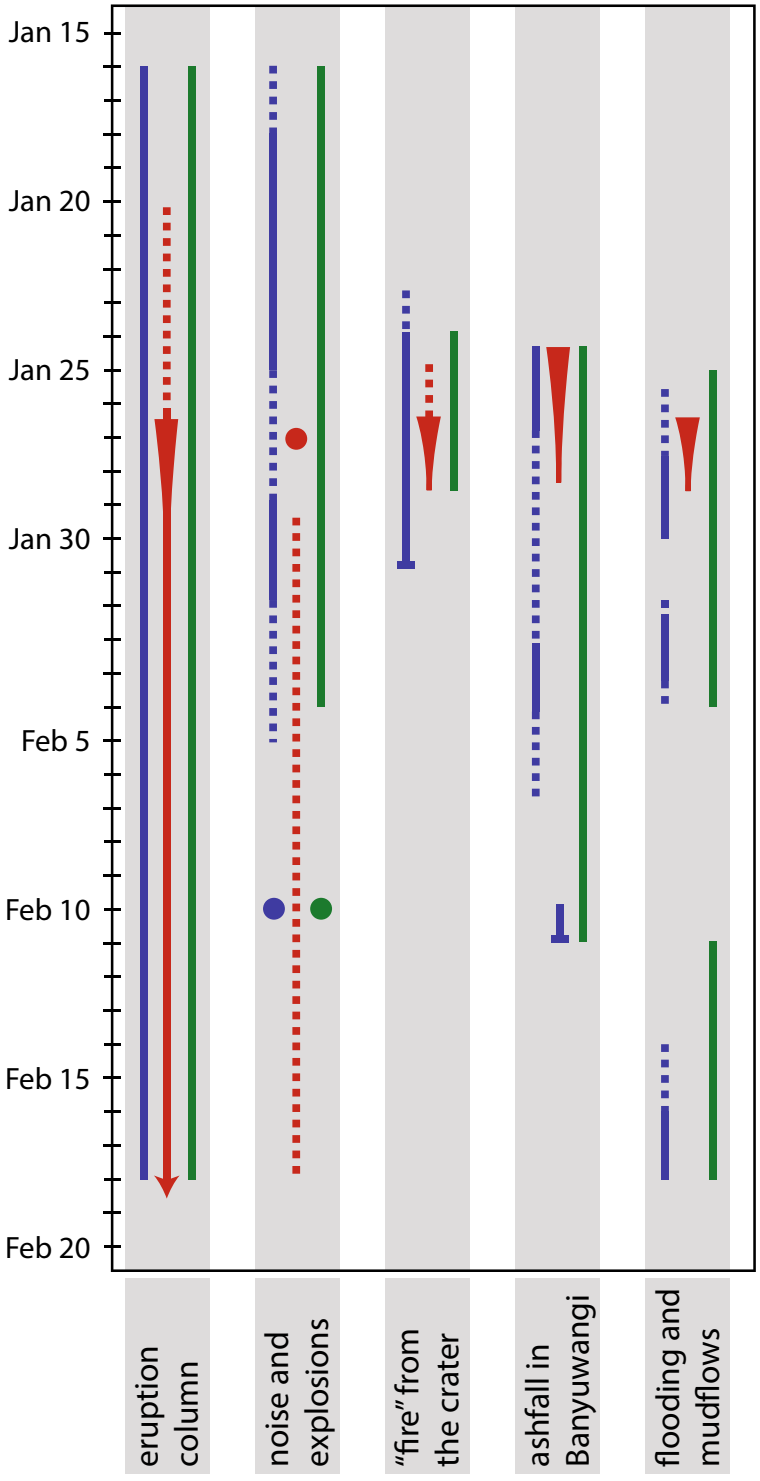

letters to superiors by Resident Roos (in Bosch 1858)

- "a European" witness report (in Bosch 1858) summary of witness reports by Junghuhn (1853) and found the area around the crater completely destroyed with trees buried in $6 \mathrm{~m}$ of ash (Bosch 1858). Smoke and "fire" prevented him from observing the crater itself. $\mathrm{He}$ returned 3 months later and found a "very deep" crater. Heavy rain had washed most of the ash away by this time. Junghuhn (1853) reported a visitor finding $\sim 1.2 \mathrm{~m}$ of ash at the foot of Kawah Ijen volcano "shortly after" the eruption.

In 1820, Resident van de Poel reported a 30 to $45 \mathrm{~cm}$ ash cover starting 3 to $4.5 \mathrm{~km}$ from the summit (Bosch 1858). The fumarole plateau was gone and the lake much larger. It was no longer possible to descend to the lake. Lake waters were bottle green with floating masses of yellow sulfur. Fumaroles were present on the lakeshore with the most active being a fracture emitting flames in the northeast (northeast from his viewpoint, which means the southeastern lakeshore). A 170-m long rope only reached halfway down to the lake.

Reinwardt (1858) reported similar observations for his 1821 visit. Dead and burnt tree stumps were found at the Ongop-Ongop plain, and the ground was covered in white mud. The lake was white with lots of fumes rising from it. Fumaroles were present on the southeastern lakeshore, one of which emitted red flames. The lake was bounded on all sides by steep cliffs except for a break in the western crater rim that led to the Banyu Pahit river (Reinwardt 
did not specify whether the river flowed directly from the lake).

In 1844 and 1845, and in 1858, the crater looked very different (Junghuhn 1853; Stöhr 1862). The lake was completely still green (Junghuhn 1853) or milk-white (Stöhr 1862 ) in color, and no fumes were rising from it. Its level was at least $15 \mathrm{~m}$ below the break in the western crater rim, and there was no direct outflow of lake water. Junghuhn (1853) traced the source of the Banyu Pahit upstream to seepage springs ca. $1.5 \mathrm{~km}$ from the lake, which are also the main source of the present-day Banyu Pahit (see Van Hinsberg 2010a; Palmer et al. 2011). Fumaroles were present in 1845 and 1858 on a small foreland just above lake level in the eastern part of the crater (Stöhr 1862), but were not observed by Junghuhn (1853). Yellowish ash covered the flanks of Kawah Ijen with fragments of greenish sulfur, but new vegetation had established itself. Damage on the outer flanks was mostly restricted to the river valleys, showing that the mudflows were channeled through these. The inner crater walls rose in cliffs to the crater rim, except above the fumaroles where the slope changed to shallow close to the rim (Stöhr 1862). This area dipped $\sim 20^{\circ}$ inward and was cut by deep erosion gullies. The description of this area fits the present-day topography perfectly.

Verbeek and Fennema (1896) provided an overview of the geology of the Ijen system, but did not comment extensively on Kawah Ijen or its activity, except for mentioning that the lake waters are cold.

The observations of the 1817 eruption indicate that it was a phreato-magmatic event. Dry ashfall was accompanied by two episodes of cold mudflows, the first possibly related to expulsion of the lake, whereas the second was related to ash mobilization by rain (Junghuhn 1853). Native sulfur was present in these mudflows and in the ash observed on the outer flanks of Kawah Ijen in 1844 (Junghuhn 1853). However, the volume of material that was deposited far exceeded the amount of sediments and sulfur that might reasonably be expected in the pre- 1817 crater, and although there was significant deepening of this crater, its actual size could not have increased substantially. This is evidenced by the similarities in the shape of the crater between 1805 and the present-day (Fig. 4), and the similar distance from the crater rim to the scarp on Merapi's flank (cf. Leschenault (de la Tour) 1858).

Comparing Leschenault de la Tour's observations to post1817 reports suggested a doubling of the depth of the crater, an increase in the size of its lake, and a significant steepening of the eastern crater rim. Kemmerling (1921) proposed three interlocking craters for the summit area of Kawah Ijen (Fig. 4), supported by the differences in level of erosion of their walls. The eastern crater had markedly steeper walls than elsewhere with much less erosional reworking. The present-day fumaroles are hosted in the southeastern part of this crater, and the area north of these consists of strongly altered rocks cut by a vein network filled with pyrite and sulfates (Scher et al. 2013). This vein network was interpreted as the feeder system of a previous fumarole area at higher elevation (Van Hinsberg et al. 2010a; Scher et al. 2013). Combining the younger crater walls in the east, the deepening of the crater in the 1817 eruption, and the location of the fumaroles in the eastern part of the crater in 1805 leads us to propose that the eastern crater was active in the 1817 event, and that the vein network is the feeder system for the 1805 fumarole field.

The post-1817 system is remarkably similar in topography to the present-day, and no significant changes in topography have occurred after 1817 .

\section{0th century}

Dutch reports In 1914, the mine engineers Van Gelder and Caron (Caron 1914; Van Gelder and Caron 1915) visited Kawah Ijen. Although this visit was mainly designed as a research trip to closely investigate the economic potential for mining sulfur, the engineers also collected observations of the volcanic lake and the overall geology of Kawah Ijen. While Van Gelder and Caron (1915) reported a temperature of $42{ }^{\circ} \mathrm{C}$ in April-May, Caron (1914) noticed a significant drop of the temperature in October $\left(33^{\circ} \mathrm{C}\right)$. Caron attributed the increase in lake temperature relative to the cooler temperature reported by Verbeek and Fennema (1896) to background fluctuations rather than to an increase of the volcanic activity. Caron proposed that the changes from green to yellow-grey color of the lake were due to the influence of the wind speed on the large amounts of very finely disseminated sulfur. When there was no wind, the water was at rest and the sulfur settled down and the lake recovered a green color (Caron 1914). According to Caron (1914), volcanic gas bubbles rising through the lake surface served as nuclei around which a sulfur skin (pushed by the wind from the fumaroles) formed, enclosing the gas. These skins got thicker and stronger by the continuous rolling of the waves, to form sulfur spherules. Caron (1914) was correct concerning the sulfur spherules on the lake surface (see Delmelle and Bernard 1994). However, the change in color depends on lake water convection rather than wind alone.

The next important investigation was by Hartmann (1917). He estimated the lake surface to be $368,000 \mathrm{~m}^{2}$ and the flow rate of the acidic water discharge (i.e., the Banyu Pahit) to $20 \mathrm{l} \mathrm{s}^{-1}$. Hartman further confirmed that the "normal" color of the lake is green. To regulate the outflow of water from the lake, and hence the input of acid water into the Banyu Putih and the irrigation system, a dam had been built on the western lakeshore. As soon as 
a height of $120 \mathrm{~cm}$ from the top of the dam was reached, water was discharged through sluices and led directly to the sea, thereby bypassing the plantations. The dam was badly damaged between the 20th and the 25th of February 1917 in a phreatic event which constituted the first precise description of a volcanic hydrothermal crisis at Kawah Ijen (Hartmann 1917). Figure 6 displays the evolution of different parameters measured in 1917. A photograph taken of this event (Fig. 7) shows that the unrest did affect the northern part of the crater. On the 20th of February 1917, the lake temperature measured on the shore was around $20^{\circ} \mathrm{C}$ (Fig. 6). During the next 9 days, it rose to at least $30^{\circ} \mathrm{C}$. Upwelling of bubbles was noted between the 25th and 28th of February. Between the 1st and 13th of March, the temperature was high and fluctuating (around $37{ }^{\circ} \mathrm{C}$ based on Hartmann (1917) and $57{ }^{\circ} \mathrm{C}$ according to Kemmerling (1919)). Water fountains reached a height of 8-10 m; white vapor clouds and mud were observed over the lake surface. The lake temperature then stabilized until the 20th of March and dropped quicker back to "equilibrium" the days after (Hartmann 1917; Kemmerling 1919). Another increase in lake temperature (to $50{ }^{\circ} \mathrm{C}$ ) was reported at the end of April in Kemmerling (1919). After that, the lake temperature sharply dropped. The influence of rainfall during the unrest was considered as weak. Although water seeped between 26/02 and 09/03 and increased evaporation was noticed, the water level remained fairly constant from the 24th of February until 12th of March.

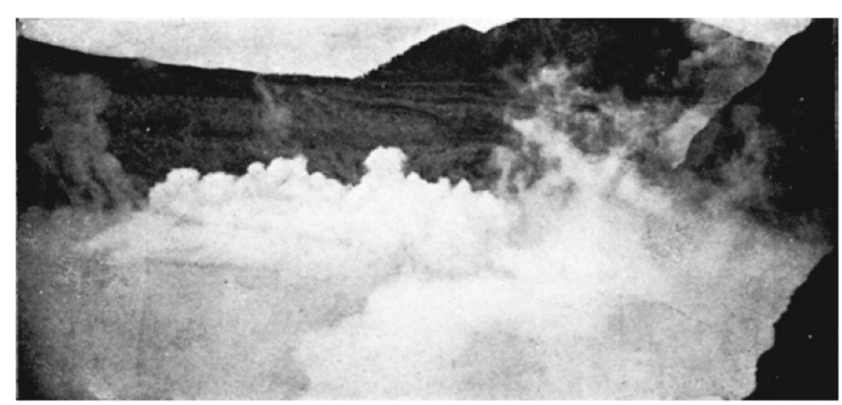

Fig. 71917 crisis from Hengeveld (1920). The picture was taken from the western part of the crater looking forward towards Merapi

It then went steadily down after the 13th of March 1917.

Hartmann (1917) interpreted the unrest as follows. A strong earthquake occurred in Bali producing significant damage and casualties (1500 victims) on January 21st 1917 (Soetardjo et al. 1985). Tremor induced by the strong tectonic earthquake that took place in the vicinity could have reopened a closed channel (Hartmann 1917). He supposed that the earthquake caused a sudden upward push of gas in the conduit below the acid volcanic lake (Fig. 8). The water column could no longer accommodate the increase in pressure and a "tidal wave" of water spilling over the dam took place until the equilibrium was restored. The subsequent

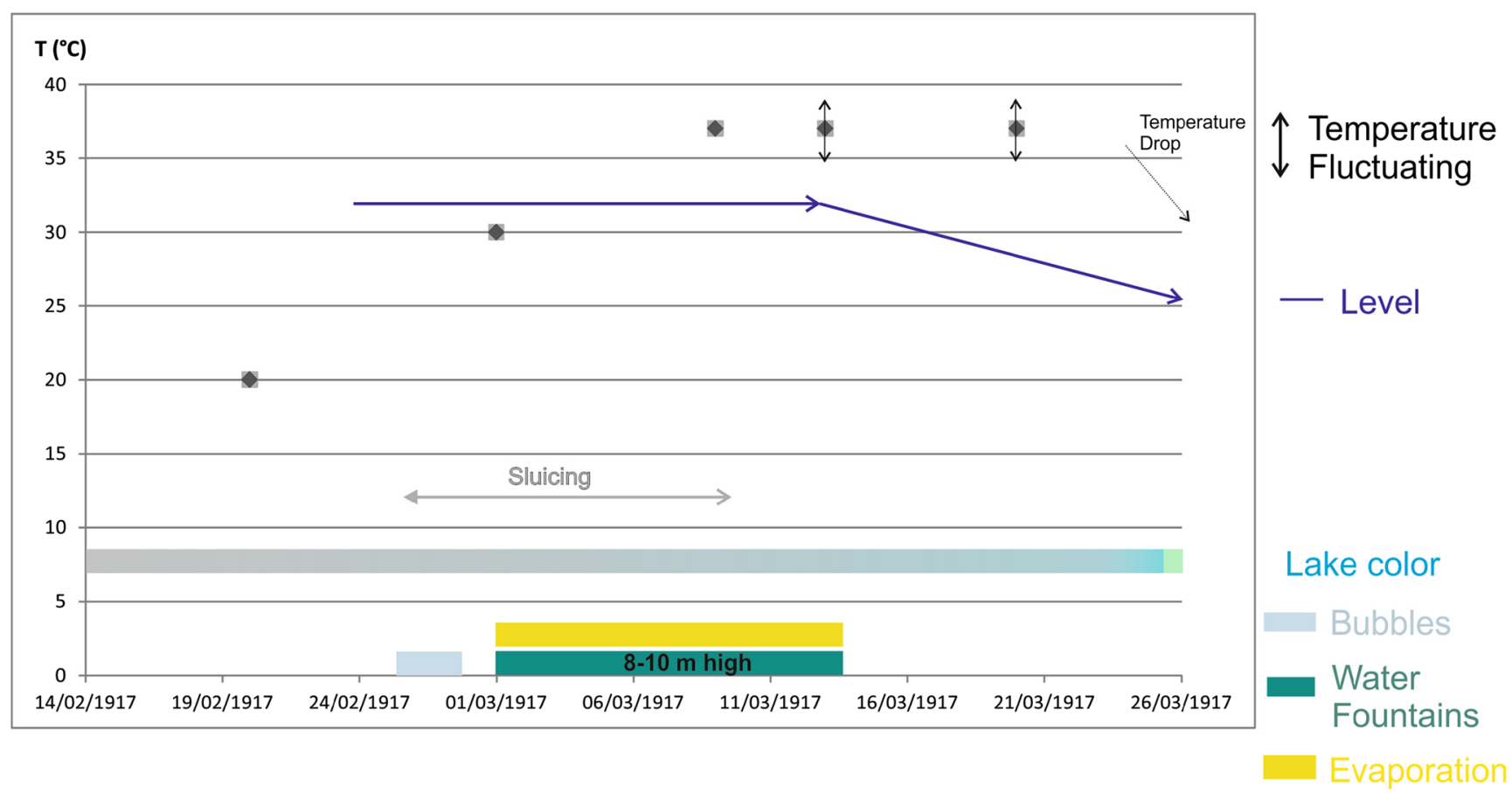

Fig. 61917 crisis from Hartman (1917) 
Fig. 8 Early interpretation of Kawah Ijen volcanic lake activity (Hartmann (1917) in Darwis (1957))
Graphic representation of periods of rest and eruption in the crater of Kawah ljen (explaining an abnormal drop and rise of the water level, that are not in accordance with rainfall, evaporation and loss of water by seepage)

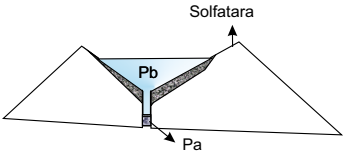

Gas pressure $\mathrm{Pa}$ lower than water-pressure $\mathrm{Pb}$ $=$ drop of lake level

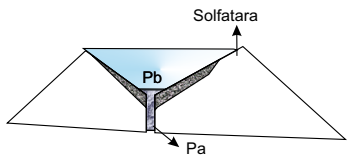

Gas pressure $\mathrm{Pa}$ higher than water-pressure $\mathrm{Pb}$ = eruption

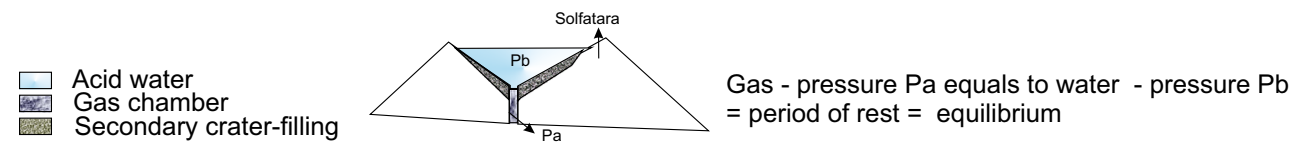

decrease in water level would increase the chances of new eruptions. This explained why the crater was unquiet for a long time after the first big tidal wave. Hartman explained that the "boiling" of lake waters may have induced secondary and smaller tidal waves. The lake water's turbulence mixed the chemical precipitates of the lake floor and caused landslides on the crater walls' which resulted in a milkywhite lake color. The overflowing waters percolated through the rocks into the Banyu Pahit, becoming green again due to the filtering effect. The lake itself got back to its green color on the 24th of March. Meanwhile, the level dropped due to a weakened gas pressure and the temperature got back to its previous value. The Banyu Pahit at Lewung (Asembagus plain) was still found acidic after the 16th of March, although there was no visible spilling of water in the crater area anymore. A few days after, the acid reaction disappeared, but the Banyu Putih was no longer white-colored.

Finally, Hartman proposed a model in which the watercolumn was sustained by the gases in the conduit pipe. Part of them was absorbed by the pipe. The remaining part gave rise to fumaroles and solfataras. The important parameters were the "height of the barometer" and the thickness of the filling in the pipe. The filling at the eastern walls was likely thicker and therefore more suitable for receiving gases than the other parts of the walls. Hartman concluded by pointing out a correlated increase in activity (i.e., ash falls) at Raung volcano, suggesting a potential connection between these active volcanoes.

An interesting comment concerning the increased upwelling in the lake after the tectonic earthquake in 1917 was found in Newhall and Dzurisin (1988). This could have been caused directly by shaking of the hydrothermal system, but also by the reduction in confining pressure caused by lowering the lake level. This has repeatedly caused an increase in fumarolic activity beneath the lake, a rise in lake temperature, and in some instances phreatic or hydrothermal explosions. Therefore, the sudden seiche and uncontrolled discharge in 1917 were probably intermediate and necessary steps in the development of that unrest (Newhall and Dzurisin 1988).

Aside from the tidal wave, both interpretations (Hartmann 1917; Newhall and Dzurisin 1988) were extremely useful and relevant. The influence of hydrostatic pressure on the equilibrium of the volcanic lake would be proven later thanks to more precise temperature measurements. The change of lake color due to enhanced turbulence in lake waters and the predominant role of gas in this type of system were two apropos and precocious interpretations.

Several strong variations occurred in the lake between 1921 and 1937 and are described by van Bemmelen (1941). In February 1921, drainage of the lake water in excess led to a rise of lake temperatures: 37 and $45{ }^{\circ} \mathrm{C}$ a week later. It was accompanied by ebullition of gas and a "boiling" noise. In 1923, the temperature increased from 40 to $49^{\circ} \mathrm{C}$ in a day (21-22/03). In 1933, it increased from 32 to $48^{\circ} \mathrm{C}$ in a day (3-4/04) and gas upwelling was noticed. Excess drainage of the lake waters in 1934 caused gas bubbling which reached a height of $2 \mathrm{~m}$. A person became ill because of the gases close to the dam, and the temperature reached $41{ }^{\circ} \mathrm{C}$. In 1935 , the temperature rose from 18 to $41{ }^{\circ} \mathrm{C}$ in a week but got back to $27^{\circ} \mathrm{C}$ a week later. In 1936, between May 3rd and 11th, strong gas emissions (Fig. 9) and a maximum temperature of $40^{\circ} \mathrm{C}$ were noticed. Between the 7 th 
Fig. 9 1936-1938-1957 Crises upwelling areas modified from Djoharman (1971)

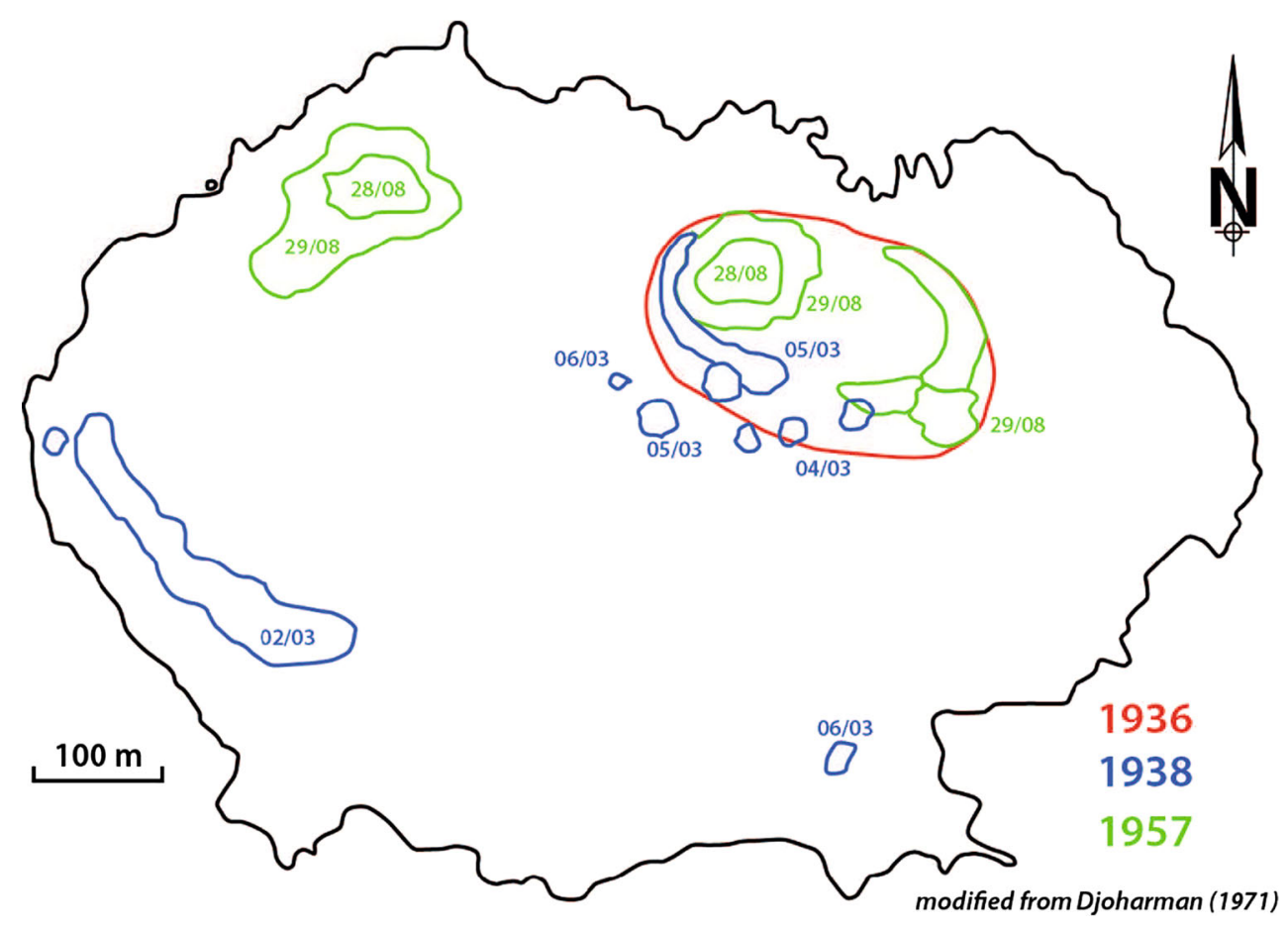

of November and the 17th, and 20th and 22nd of November, abnormal rises of the lake level, gas bubbling, water fountains, and upwelling of bubbles (height of $50 \mathrm{~m}$ ) were observed. The temperature remained at $42{ }^{\circ} \mathrm{C}$ until December. In 1937, the temperature was high during the greatest part of the year $\left(35-42{ }^{\circ} \mathrm{C}\right)$ and decreased in December due to cooling rain.

Stehn (1938) reported precise observations of an unrest (Fig. 10). An abnormal drop of lake waters of $8 \mathrm{~cm}$ in $10 \mathrm{~h}$ occurred on the 21 st of January 1938. In contrast, on the 2nd

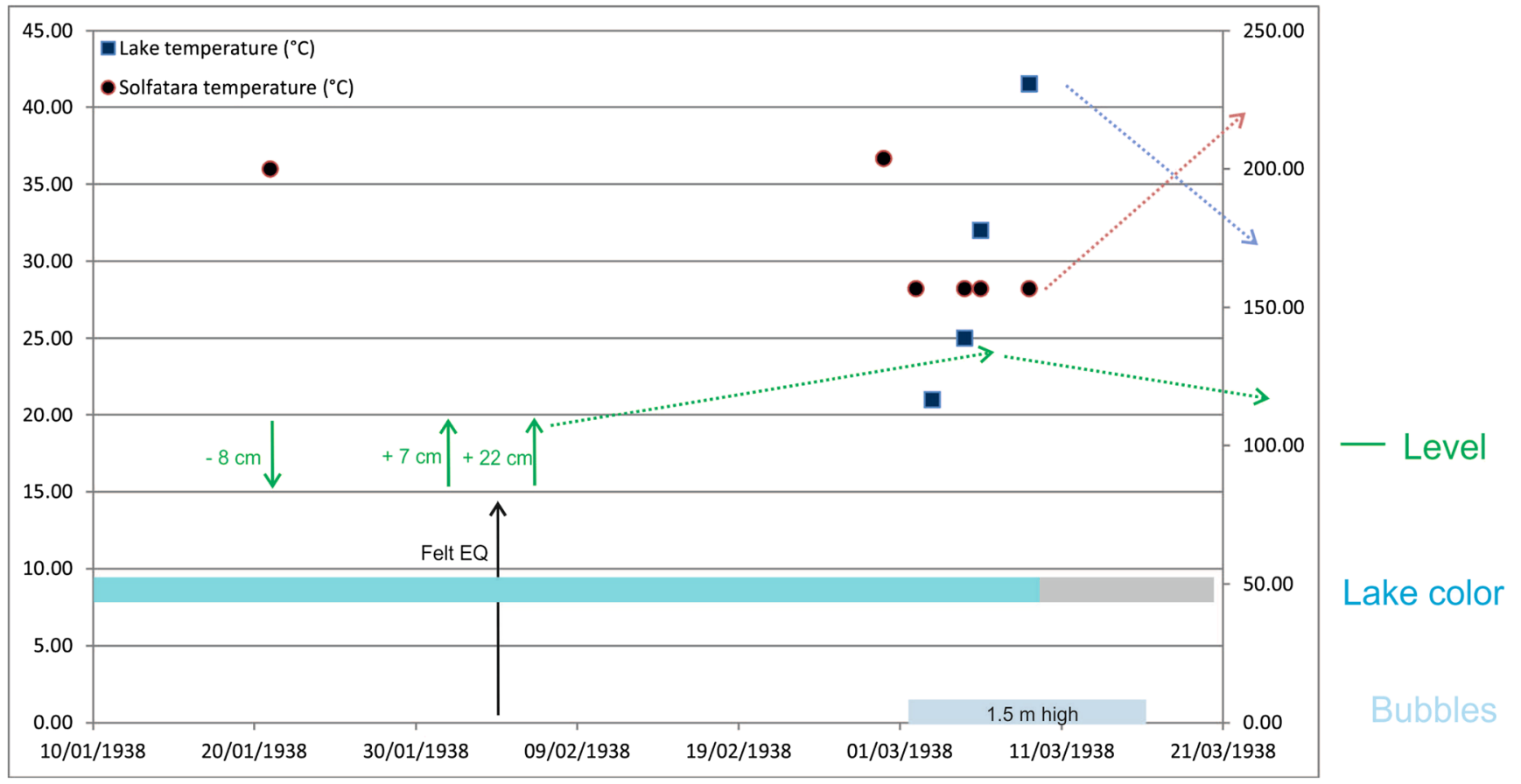

Fig. 101938 crisis from Stehn (1938). Left axis: lake temperatures and right axis: solfatara temperatures 
and 8th of February, the lake level increased by 7 and $22 \mathrm{~cm}$. In the morning of the 7 th of February, the rise was preceded by a seismic event (2-min long). On the 2nd of March, gas bubbles were noticed close to the dam (Fig. 9).

On the 5th of March, bubbles formed in the center of the lake and reached a height of 1-1.5 m (Fig. 10). Within 2 days, the temperature increased from 21 to $25^{\circ} \mathrm{C}$. Between the 5th and 6th of March, the water heated from 24 to $32{ }^{\circ} \mathrm{C}$. The lake level reached its maximum height the same day. Gas rumblings were also noticed. On the 9th of March, the lake waters became troubled and white and the temperature rose to $41.5^{\circ} \mathrm{C}$. Some bubbles were noticed around the dam and rumblings were heard until the 15th of March. The temperature remained above $30{ }^{\circ} \mathrm{C}$ for the whole year. The lake reached its lowest level early November. It then increased again due to the rainy season. Temperature profiles of the solfatara were anti-correlated (January: 199. ${ }^{\circ} \mathrm{C}-28 / 02: 203.6{ }^{\circ} \mathrm{C}-\mathrm{March}: 156 .{ }^{\circ} \mathrm{C}$ ) to temperature/level patterns. After the unrest, the temperature of the solfatara rose again until mid-November $\left(\mathrm{T}=190.7^{\circ} \mathrm{C}\right)$. The temperature decreased until the 24th of November $\left(169{ }^{\circ} \mathrm{C}\right)$ for increasing again until the 6th of December and then being kept constant $\left(\mathrm{T}=180.8^{\circ} \mathrm{C}-182^{\circ} \mathrm{C}\right)$. The lake bottom was significantly affected by the volcanic unrest.
A year later, in 1939, Stehn (1939) provided a complete description of the volcanic activity and lake changes. In the night of 12th of February, numerous gas bubbles were noticed close to the dam and to the SW of the lake. The lake temperature rose from 28 to $37^{\circ} \mathrm{C}$ between the 12th and 14th of February in the evening. The upwelling areas extended then to the S and NW. Landslides occurred on the north and were particularly vigorous between the 23rd and 26th of February. Bubble upwelling at the surface stopped after the 28th of February. Lake temperature then dropped. Small bubbles were observed between the 8th and 10th of March and were likely strong during the night of 10-11 March, as the temperature rose to $37{ }^{\circ} \mathrm{C}$ again. From the 22nd of March, bubble upwelling occurred on the north and west, on the 24th started also on the east and on the 25th in the center of the lake. Between the 27th and 31st March, the dam was opened to release lake waters. On the 3rd of April, the temperature was $42{ }^{\circ} \mathrm{C}$. Apart from the lake shores, bubbling also appeared at three places in the middle of the lake above the eruption sites of November 1936 and in the eastern part.

The authorities constructed an observatory at the summit and a 21-m-long tunnel secured enough to install a seismometer. The northern extremity of the tunnel contained a porthole to allow for safe observations of the lake. This

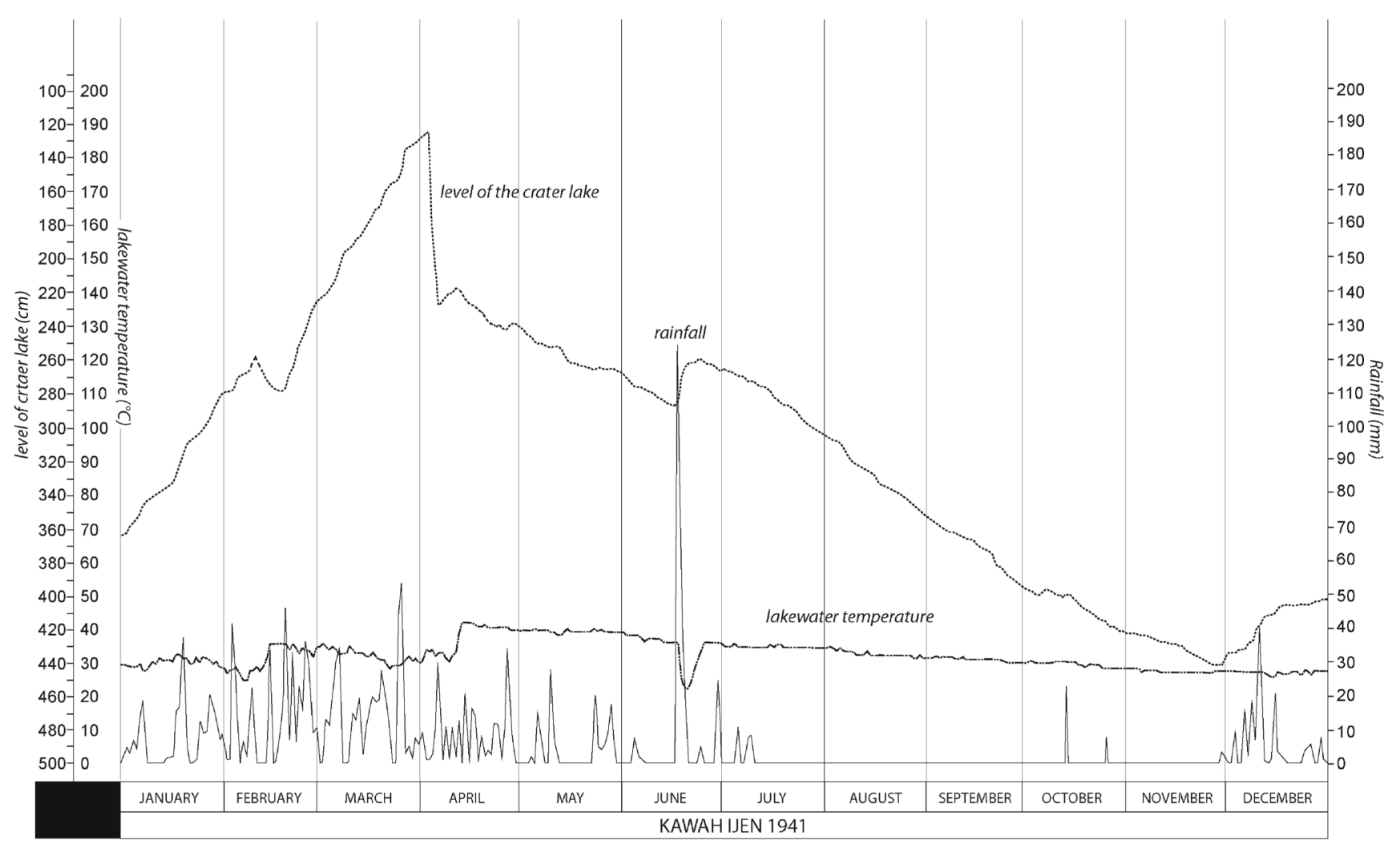

Fig. 111941 monitoring time series. The drainage of the lake caused an increase in the lake temperature 
concrete installation and refuge tunnel were completed in 1939.

In February 1940, gas bubbling caused a hissing noise. During the whole month of March, gas bubbling and upwelling were noted and the lake reached a temperature of $45^{\circ} \mathrm{C}$. The lake became whitish (presumably due to gypsum (van Bemmelen 1941)). van Bemmelen (1941) finally reported draining of lake waters on March 3rd-6th 1941 caused upwelling of gas (0.5-m high) (Fig. 11). The maximum measured temperature was $43^{\circ} \mathrm{C}$. The enhanced upwelling might be explained by the sudden decrease of the hydrostatic pressure induced by the lake on the hydrothermal system which allowed the bubbles to rise upper in the water column.

Indonesian reports After 1945 and the Indonesian independence, the reports were mostly written by Indonesian scientists.

In 1952, Djoharman (1971) (apparently based on Kusumo (1950-1957)) reported an explosion on the 22nd of April at 6:30 a.m. A smoke plume reached $1 \mathrm{~km}$ above the crater and avalanches were heard from Sempol ( $\sim 5 \mathrm{~km}$ far from Ijen). In the crater, water explosions were 7-m high. No victims were reported.

Darwis (1957) and Djajawinangoen (1957) reported small bubbles (in areas of several meters) at the surface and strong water currents. The lake temperature rose by $9{ }^{\circ} \mathrm{C}$ in 3 days (between the 28th and 30th of August 1957) after a linear increase during the whole month. The temperature then decreased from 46 to $42{ }^{\circ} \mathrm{C}$ in a week. The lake color was described as green-blue.
Wahyudin et al. (1993) mentioned the explosion of gas slugs (diameters of $10 \mathrm{~m}$ ) at two places in the center of the lake on the 1st of April 1962 (Fig. 12). On the 18th of April (at 07:42 a.m.), a raft of bubbles (diameter $6 \mathrm{~m}$ ) was noted in the northern part of the lake. Two hours later, the diameter reached 15-20 m. At 12:15 a.m., three gas explosions occurred (height of $10 \mathrm{~m}$ ) accompanied by a strong sulfur smell. The color of the lake shifted to whitish green.

\section{Discussion}

Mueller (1957a) mentioned that between 1917 and 1957, the lowest temperature ever recorded was $15^{\circ} \mathrm{C}$ while the highest was $50{ }^{\circ} \mathrm{C}$. The mean temperature was $30^{\circ} \mathrm{C}$. Interestingly, the maximum rate of decrease in mean lake temperature appeared to be around $15^{\circ} \mathrm{C}$ per year, while increases up to $20^{\circ} \mathrm{C}$ appears to have occurred in a matter of a few days. Nevertheless, Mueller pointed out that these anomalies should be local and represent a small batch of hot waters.

Temperatures measured at fumaroles did not reflect increases in volcanic activity and were not correlated to volcanic lake temperatures. This could indicate different pathways between the volcanic lake and fumaroles, as suggested by Hartmann (1917). Reported fumarole temperatures were less than $250{ }^{\circ} \mathrm{C}$ and likely represented the temperature of the fumarole gas at the exit of the pipes used by the sulfur miners, in agreement with temperatures measured at these pipes at the present day $\left(180-210{ }^{\circ} \mathrm{C}\right)$, but in sharp contrast to the temperatures at the vents on top of the dome
Fig. 12 Sketch of Kawah Ijen bubbles location in 1962 from Bilal in VSI (1981). Dashed contour line represent the lake shores as sketched by Bilal while grey lines are the contours as in Djoharman (1971)

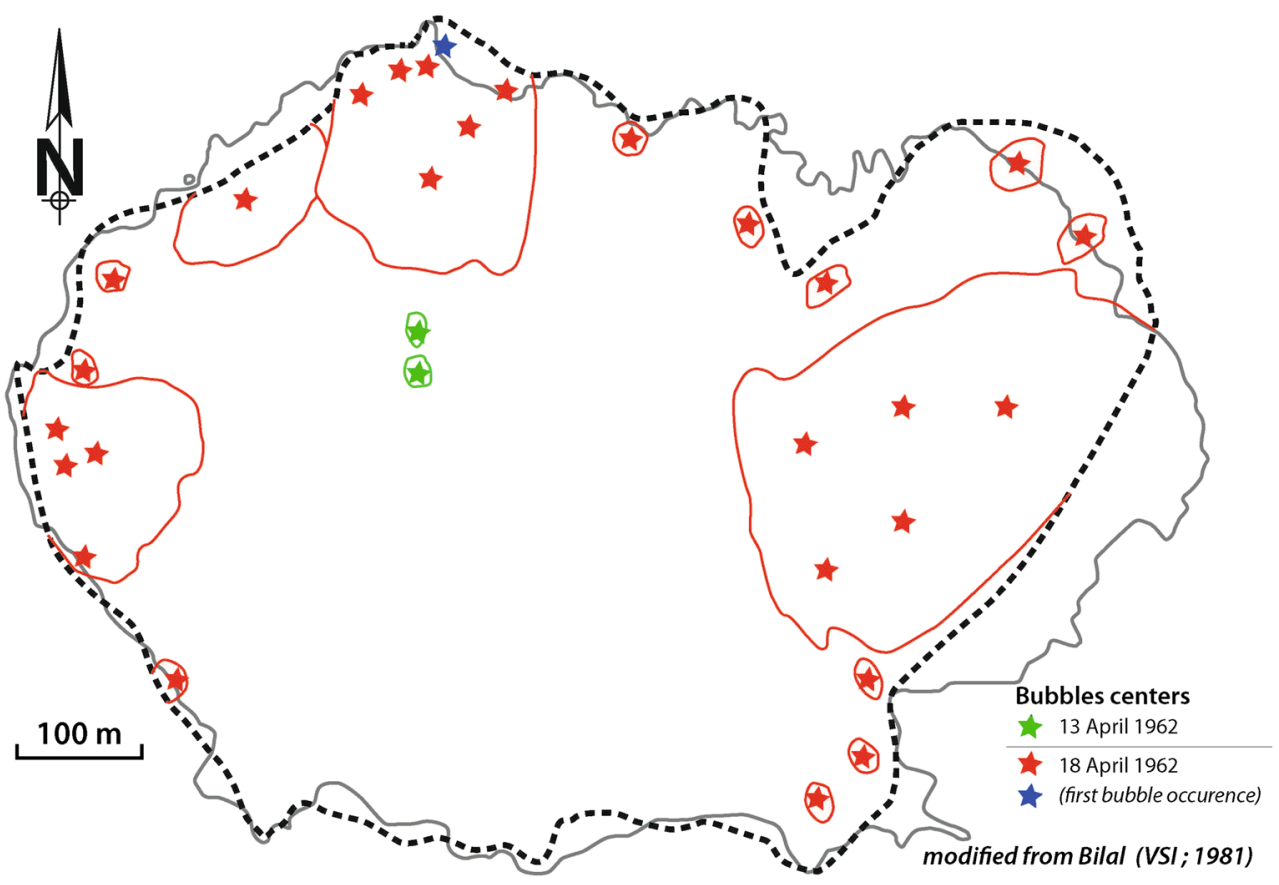


(350-450 ${ }^{\circ} \mathrm{C}$ ). Pipe temperatures appear to be buffered by condensation of liquid sulfur and are unlikely to accurately reflect or track vent temperatures. The volcanic lake likely lies above the main conduit and its temperatures are therefore more relevant for monitoring the volcanic activity. However, its volume buffers the small pulses of hot water and only larger disturbances are expected to be measured at the surface. Upwelling of bubbles are mostly observed on the lake shores. The fact that hydrostatic pressure is less important on the shores might explain this observation, as for Kelud volcanic lake (Caudron et al. 2012). Only during strong crises, large bubbles are able to reach the surface at the center of the lake. Generally, the increases of lake temperature were coupled to upwellings of bubbles at the surface. Finally, a white-colored lake implies enhanced convection and is usually associated with a period of unrest.

Geochemistry of the lake

Kawah Ijen's hyperacidic crater lake has attracted attention from (geo)chemists going as far back as Wisclenius, who analyzed a sample taken by Leschenault de la Tour in 1805 (Leschenault (de la Tour) 1858). Junghuhn reported data on a sample of lake seepage that he collected in 1844 (Junghuhn 1853). Although these early analyses were qualitative, they do confirm that the lake has been highly acidic for at least 200 years, and that it has always been dominated by sulphuric acid. Woudstra (1920) provided the first comprehensive quantitative data on the lake water composition, which were followed by regular analyses every few years, as discussed by Mueller (1957a, b). Mueller was sent to Kawah Ijen to investigate the crater lake's economic potential in terms of gypsum, carbon dioxide, aluminium sulphate, and plaster of Paris. He analyzed the chemical composition of 32 sample points ranging from 7 to $127 \mathrm{~m}$ below the lake surface. Twelve other samples were collected from the surface or a depth of $3 \mathrm{~m}$ at 6 locations. Unfortunately, there was only one analysis published which was assumed to be representative of the mean bulk composition (Table 1). The differences between all samples did not exceed $\sim 2000 \mathrm{ppm}$ of $\mathrm{H}_{2} \mathrm{SO}_{4}$. From all the samples he collected, only two

Table 1 Geochemical compositions from Mueller (1957a). Analysis made at Balai Penjelidikan Kimia lab in Bogor, Indonesia

\begin{tabular}{ll}
\hline Constituents & Concentrations $(\mathrm{g} / \mathrm{l})$ \\
\hline $\mathrm{SO}_{4}^{2-}$ & 57.0 \\
$\mathrm{Cl}^{-}$ & 17.7 \\
$\mathrm{Al}^{3+}$ & 5.08 \\
$\mathrm{Fe}^{2+}$ & 1.58 \\
$\mathrm{Mg}^{2+}$ & 0.63 \\
$\mathrm{Na}^{2+}$ & 1.05 \\
\hline
\end{tabular}

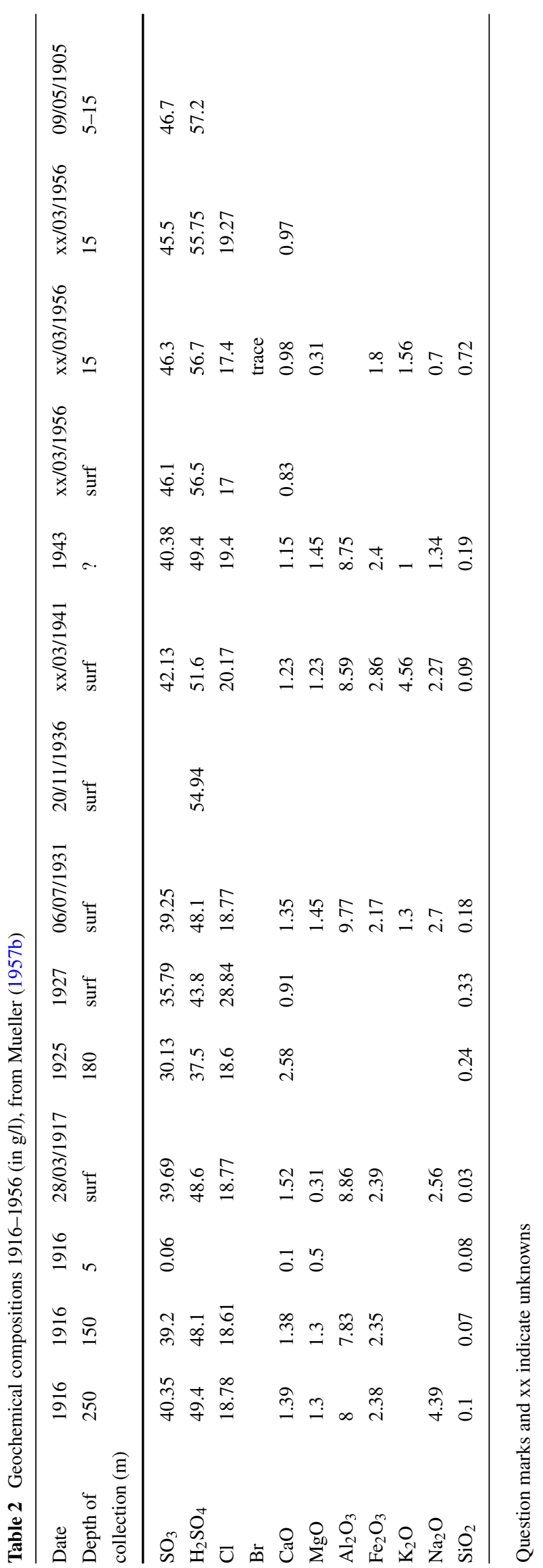


were analyzed at the same time and showed a $\sim 5000 \mathrm{ppm}$ difference in $\mathrm{SO}_{4}$ content.

Based on the chemical analyses of the previous 40 years (1916-1956), pronounced fluctuations have taken place over this period of time. But one should be careful when interpreting these changes, as discussed by Muller. Indeed, the 15 samples collected over the past 40 years have been sampled at different locations and at different times during the year (Table 2). The author believed that the differences in $\mathrm{H}_{2} \mathrm{SO}_{4}$ contents observed over a period of time did not indicate changes in the overall content of the lake, but did reveal the presence of short-time and/or local differences in concentrations. Short-time differences can occur due to seasonal effects, i.e., the surface waters can be diluted during the rainy season as was observed by Sumarti (1998), while evaporation concentrates the sulfates during the dry season at the same sampling points. Similarly, convection currents can induce spatial but also temporal differences which do not reflect a global change in the lake composition. Finally, faulty techniques in the collection or storage of samples (e.g., according to Mueller 1957b, Kemmerling's sample could not be have been taken at the depth he claimed using the technique described in Kemmerling 1921) may have introduced artefacts in the compositions. Mueller (1957a, b) then compared his most "representative" sample with the one which he believed to be closely representative of the mean concentration among the 15 odd samples collected for the past 40 years by other teams (Table 2). The selected sample was collected in November 1936 during a long series of violent upwelling in the center of the lake whose chruning action would tend to homogenize the lake solution. Sulfate concentrations of both samples were similar. Without describing his technique to sample at depth, an unidentified member of the volcanological survey staff collected a group of samples weekly from the same point near the center of the lake at a depth of $100 \mathrm{~m}$. This was done in order to detect and trace changes in the chemical makeup of the water over a period of time. The analyses revealed strong fluctuations in the acid content over short periods of time.

Hence, as suggested by Mueller, the random nature, the differences in analytical techniques, and unreliability of many of sampling attempts does not permit reliable conclusions to be drawn concerning the geochemical variations of lake waters.

\section{Bathymetry}

The first lake volume was estimated in 1922 (Taverne (1923) in Takano et al. (2004)) (Table 3). While in October 1925, based on 243 lead soundings, the deepest point was $198 \mathrm{~m}$, the same location did only measure $105 \mathrm{~m}$ in November 1936 (Stehn 1938). The deepest point had been displaced to the west and reached at that time $200 \mathrm{~m}$. The highest temperature was found at a depth of $197 \mathrm{~m}$ and was $49^{\circ} \mathrm{C}$. Based on the lead soundings, the volume was estimated to be 36.26 million $\mathrm{m}^{3}$ (Table 3 ). In preparation of the Ijen crater project, Mueller (1957a) requested a program for sounding the lake. Two hundred three depths measurements were done in August 1957 and were used to draft bathymetric maps at two scales (1:1000 and 1:2500 with contour intervals of 5 to $10 \mathrm{~m}$, respectively). He calculated the areas enclosed by each $10-\mathrm{m}$ contour. The lake volume is the sum of the 10-m vertical sections and equals 36.721790 million $\mathrm{m}^{3}$ (Table 3 ).

Differences in volumes were attributed to the filling of the lake crater. van Bemmelen (1941) pointed to two origins: landslides from the alteration of the crater walls and/or magmatic intrusion.

\section{Seismic monitoring}

The seismic monitoring system was installed close to Paltuding but the transducer amplifier was hit by lightning in 1985 (Sutawidjaja and Supartono 1987). In May 1987, a Ranger SS-1 vertical component seismometer with a PS2 portable recorder was installed by Mrs Igan Supriatman, Herry Supartono (VSI) and Dr. Elliot Endo (USGS). They installed an RTS system at the summit. The transmitter was placed in the tunnel to protect it from humidity. The frequency used for VCO (telemetry housing) telemetry and radio $\mathrm{VHF}$ transmitter were, respectively, $1700 \mathrm{~Hz}$ and 165.8093 MHz. Due to the high level of seismic noise, the gain was set to $36 \mathrm{~dB}$. The seismic vibration was more
Table 3 Year, reference, lake volumes, and method of analyzing

\begin{tabular}{lll} 
Kawah Ijen lake volumes & \\
\hline 1922 (Taverne 1923) in Takano et al. (2004) & $4.35 \times 10^{7} \mathrm{~m}^{3}$ & Lead soundings \\
1923 (Taverne 1924) in Takano et al. (2004) & $4.23 \times 10^{7} \mathrm{~m}^{3}$ & Lead soundings \\
1925 (Stehn 1938) & $4.42 \times 10^{7} \mathrm{~m}^{3}$ & Lead soundings \\
1936 (Stehn 1938) & $3.63 \times 10^{7} \mathrm{~m}^{3}$ & Lead soundings \\
1956 (Mueller 1957b) & $3.67 \times 10^{7} \mathrm{~m}^{3}$ & Lead soundings \\
1996 (Takano et al. 2004) & $3.0 \times 10^{7} \mathrm{~m}^{3}$ & Echo soundings \\
2010-2011: this study & $2.75 \times 10^{7} \mathrm{~m}^{3}$ & Echo soundings
\end{tabular}


important than at Kelud volcano (Central Java, Indonesia). The receivers were installed in the observatory of Kawah Ijen. Seismic data can be recorded using a circular drum paper.

\section{Database using the reports since 1991}

All the historical information that we could gather and that we judged reliable has been encoded in a database (available trough WOVOdat (http://www.wovodat.org/)). The following sections take into account those measurements, BGVN reports (Global Volcanism Program, USGS: www.volcano. si.edu) describing the unrest, and special reports that were found in the observatory of Kawah Ijen or at CVGHM library in Bandung.

Preliminary remarks

Phreatic eruptions were often mentioned in the reports and mostly corresponded to explosion of gas/steam at the surface. Materials that were ejected were probably landslides debris or lake sediments rather than ash. For clarity, these manifestations are termed hydrothermal events here.

Volcanic lake evolution between 1991 and 2010 is given in Fig. 13. Locations of the temperature measurements
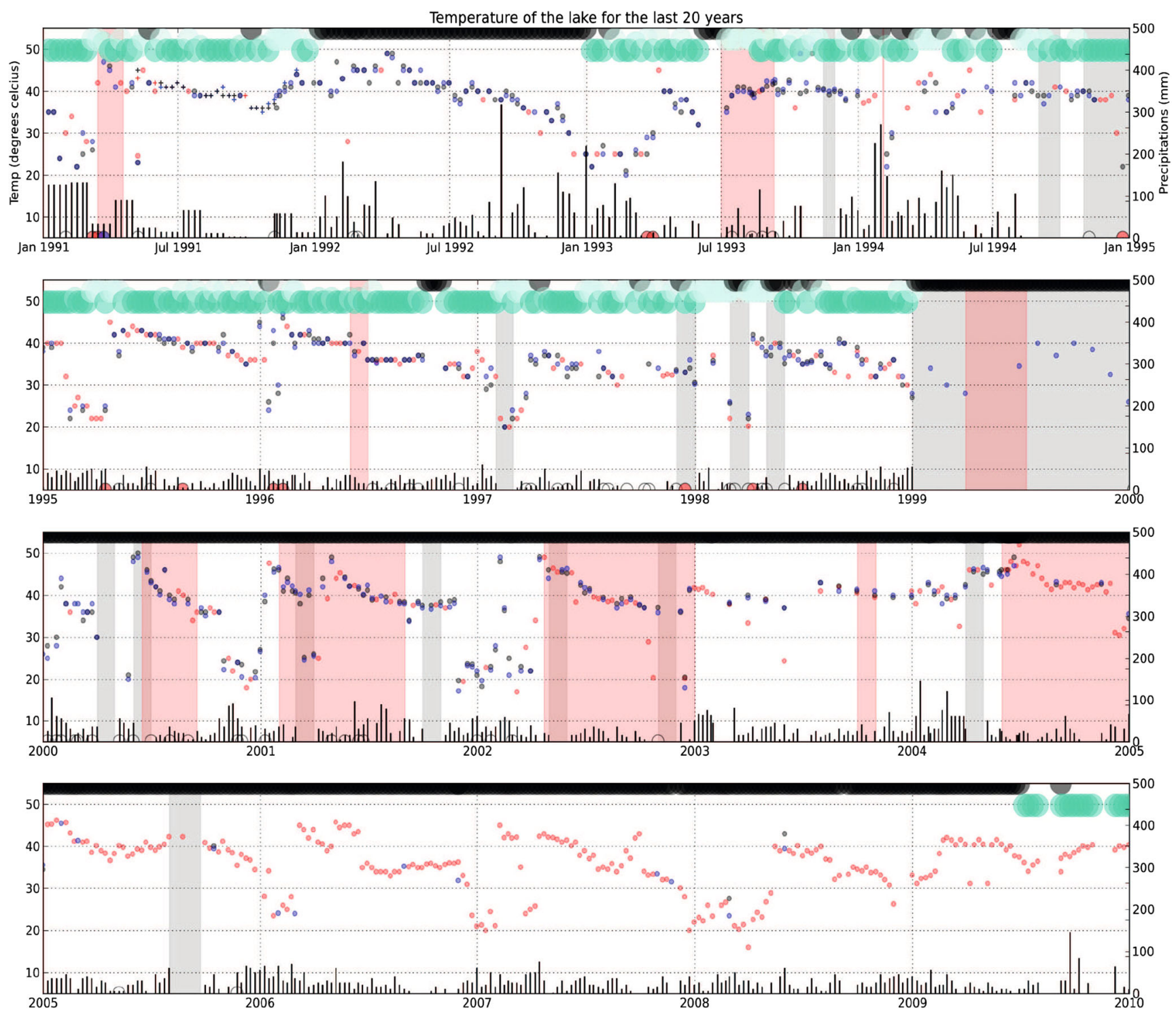

\begin{tabular}{|c|c|}
\hline$\cdots$ T_DAM & ${ }^{+++}$T_Sibanteng_(1m depth) \\
\hline+++ T_DAM_(1m depth) & $\infty$ T_Solfatara \\
\hline .०० T_Sibanteng & +++ T_Solfatara_(1m depth) \\
\hline
\end{tabular}

Fig. 13 Volcanic lake evolution between 1991 and 2010. See text for details 
are displayed in the legend at the bottom of the graph. Lake colors are shown at each upper part of the subplots (usual color: green/unusual color: green whitish/no color reported: black). Rain measured at Kawah Ijen Observatory, Tamansari (Licin, Banyuwangi regency) correspond to black bars ( $\mathrm{y}$-scale on the right sides of subplots (mm)) and observations of bubbles (half circles: white: no bubbles / blue: small bubbles (i.e., rafts of bubbles) / red: large bubbles ("tumescence" at the lake surface)) are plotted at the bottom of each subplot. Light grey shadings represent a gap in the rain measurements. Light red rectangles indicate approximate periods of unrest. Locations for the temperature measurements were Sibanteng and solfatara (corresponding to two locations near the fumarole field (Fig. 3)), and dam (Fig. 3). The temperatures measured between 2000 and 2005 by Trunk (2008) using ASTER thermal satellite imagery products were in agreement with the temperatures reported here.

An important remark concerns the reliability of the temperature measurements. The temperature curve demonstrates a seasonal variation. The minimal temperatures were usually reached during the rainy season (October to June). Two exceptions were observed in 1991 and 1992. For those periods, temperature measurements at depth $(1 \mathrm{~m})$ were available and the seasonal trend was inverted with a peak during the rainy season. Obviously, the temperature measured at the surface during the rainy season did not reflect the real temperature of the lake. Temperatures of the lake lower than $30^{\circ} \mathrm{C}$ are extremely unlikely to be representative for overall lake temperature. We also distinguish between small bubbles and very large bubbles. The former are rafts of bubbles which intersect the lake surface over a defined area (two phases: gas and liquid), whereas the latter likely correspond to a sudden release of accumulated gas in the porosity of lake sediment (three phases: gas, liquid, and solid particles, also observed, for example, at Ruapehu volcanic lake (R.W. Henley, pers. com.)). Small rafts of bubbles are always observed, contrarily to the "tumescence" of several meters diameter and height which are mostly associated to strong volcanic unrest (R.W. Henley, pers. com.)

The second graph (Fig. 14) portrays the volcano seismic activity between 1991 and 2010 (number of events and continuous tremor amplitude in $\mathrm{mm}$ ). Light grey shadings represent a gap in the seismic measurement. Between 1999 and 2000 , the number of events were only reported every month, whereas for the rest of the graph, a weekly number of events was available. Light red rectangles indicate approximate periods of unrest.

As digital seismic data were not available before 2010, the observers of Kawah Ijen observatory mostly classified the volcano seismic events based on the Minakami classification (Minakami 1974), without performing any spectral analysis. The five basic types of events were thus determined based on a waveform inspection on analog paper recordings and on empirical features. The first step carried out by the observers was (and still is) the identification of $\mathrm{P}$ and $\mathrm{S}$ waves. If those phases were clearly seen, they measured the time difference (S-P) between the phase arrivals and the events fell into one of the three classes: "Tectonic Jauh" (or Tectonic Far) (S-P > 10 s $\sim 50 \mathrm{~km}$ ), "Tectonic Local" (10 s > S-P > $4 \mathrm{~s}$ or $\sim 20 \mathrm{~km}$ ), or 'Vulkanik A' (S-P $<4 \mathrm{~s}$ ). On the other hand, if there was no clear $\mathrm{S}$ phase, the recorded seismic event represented the waveform and duration features of a "Vulkanik B," a Hembusan," a "Harmonik Tremor," or a "Tremor." A Vulkanik B is a short duration signal (less than $10 \mathrm{~s}$ ) with an emergent arrival. Hembusan are more impulsive signals and are attributed to degassing. Tremor represents more sustained vibration of the ground. Harmonic tremor is typically recorded during the volcanic crises and is usually monochromatic. Although we propose a revised classification at the end of the study (see "Towards a unified seismic classification" section), this scheme provided interesting insights into the historical activity, as it did not experience striking changes since the 1990s.

Volcanic activity during the 1990 s

On the 15th of March 1991, Sukhyar (1991) reported a raft of bubbles at the surface which later (on the 21st and 22nd of March) expanded to $5 \mathrm{~m}$. The lake color changed from the usual green shade to brown. Those changes led the Director of the Volcanological Survey of Indonesia to close the sulfur mine for 2 weeks (16-30th March 1991). The miners reported gas explosions (25-50-m high) spreading fast in a horizontal direction. The seismometer captured these bursts as tremor on the 16th of March. The tremor was continuous until the 25th of March, then became discontinuous until the 18th of April. It took the form of a banded tremor lasting for 1 to $3 \mathrm{~min}$ with an interval of 2 to $4 \mathrm{~h}$. No tremor was recorded after this date. The temperature was measured 1 week before the onset of bubbling at the surface and was $20{ }^{\circ} \mathrm{C}$. It increased to $40{ }^{\circ} \mathrm{C}$ a week later and did not go down, although the tremor stopped. Sukhyar (1991) concluded by saying that further research was needed to understand the link between both parameters. He also pointed to the fact that no precursor could be found with the seismic data acquired. This crisis was completely different from the crises that later happened. The 1991 unrest was characterized by an important number of continuous-discontinuous tremor periods. Excepting an important number of tectonic local events, really few volcano seismic events were recorded.

Wahyudin et al. (1993) reported a sequence of explosions on the 3-4-7/07 and 1/08 of 1993 (Fig. 15). The day before 
the first explosion, the lake color was normal (green). On the 11th of July, the lake color turned to whitish and the sulfur smell was extremely strong ("hurting the eyes"). The temperature then increased (Fig. 15).

The other observations related to the sulfur spatial occurrences were not relevant as they could be only influenced by wind direction. The 3rd July 1993 event (08:45 a.m.) was captured by P. Blonde (Fig. 16). As can be seen on the picture, a large bubble appeared in the middle of the lake. A high pressure and a strong noise were noted. Before the explosion, the lake color was green whitish. Following it, the color turned to brown and its surface became dark. These observations were made by 14 sulfur miners and 3 French tourists who were in the crater. The height of the plume was estimated to $75 \mathrm{~m}$. The next day, at 08:35, another explosion reached a height of $35 \mathrm{~m}$ and at 10:45, another one but of weak pressure and without noise. On the 7th of July, at 02:15 a.m., another event was heard at the Pondok ( $1 \mathrm{~km}$ far from the crater). Two explosions were also heard on the 1st of August (16.35 am) at the Pondok. Those events were preceded by a seismic event felt around the Puncak (Tectonic Jauh of Amax = $46 \mathrm{~mm}$ ). The plume reached a height of $500 \mathrm{~m}$ and a strong sulfur smell was noted around the Pondok. Even though explosions at the surface were only reported in July and August 1993, the absence of similar events described in September and October could be due to bad weather conditions which prevented visual observations. A transition could also be observed in the type of activity. In terms of seismic events, between May and August 1993, a large number of VA were recorded (with S-P $\sim 0.5-1$ s) (Fig. 17). While a return to normality was mentioned by the 10th of September in BGVN (1994a), the measurements went against this conclusion. In September and October 1993, the
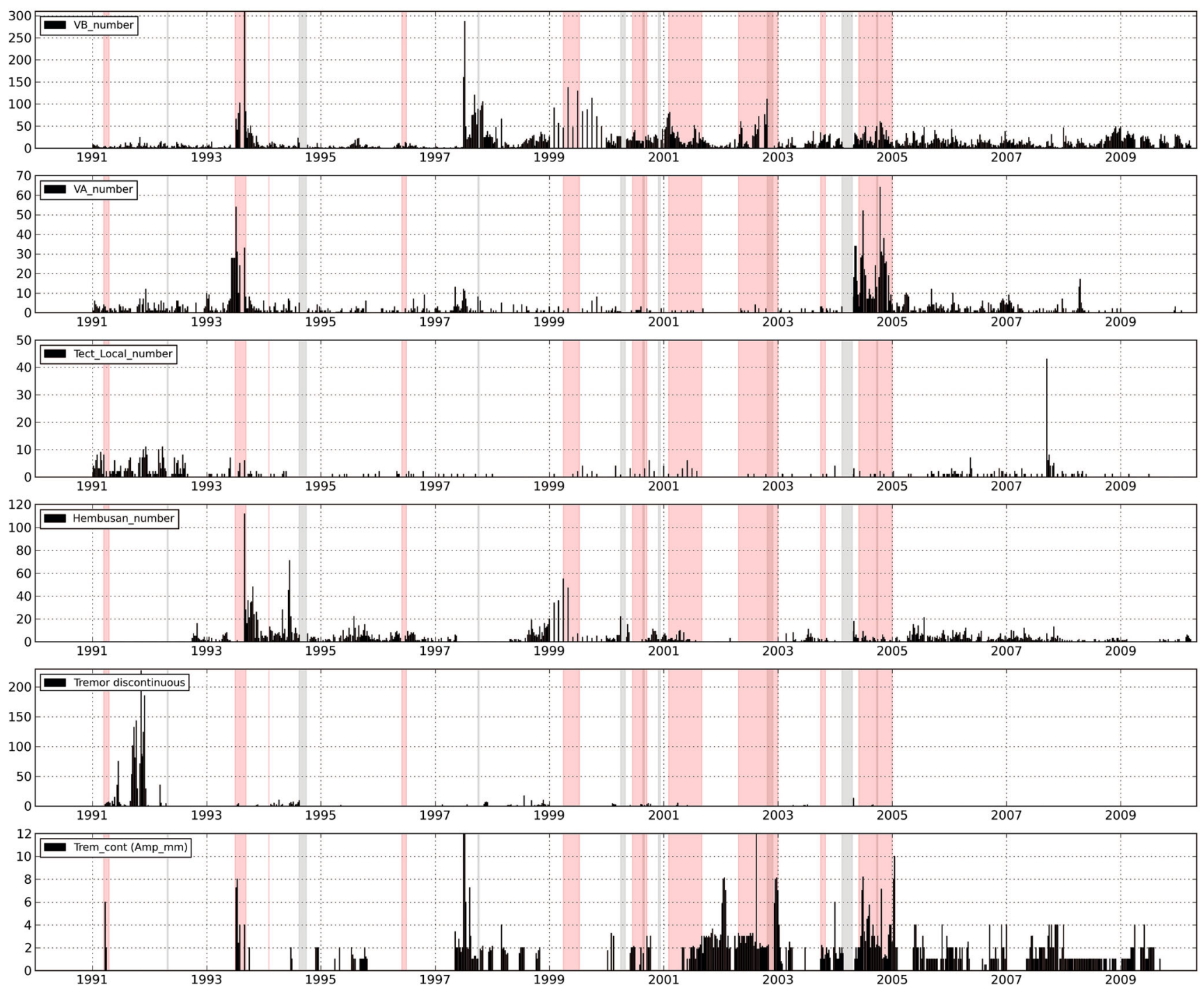

Fig. 14 Number of seismic events between 1991 and 2010 and continuous tremor amplitude (in mm). See text for details 
Fig. 151993 Hydrothermal explosions (3-4-7 July) crisis. Upper plot: temperature evolution (in ${ }^{\circ} \mathrm{C}$ ); lower plot: cumulative energy (in ergs) of the volcano seismic events (black) and continuous tremor amplitude (blue) modified after Wahyudin et al. (1993)
Fig. 16 03/07/1993 explosion (with the courtesy of P. Blonde)
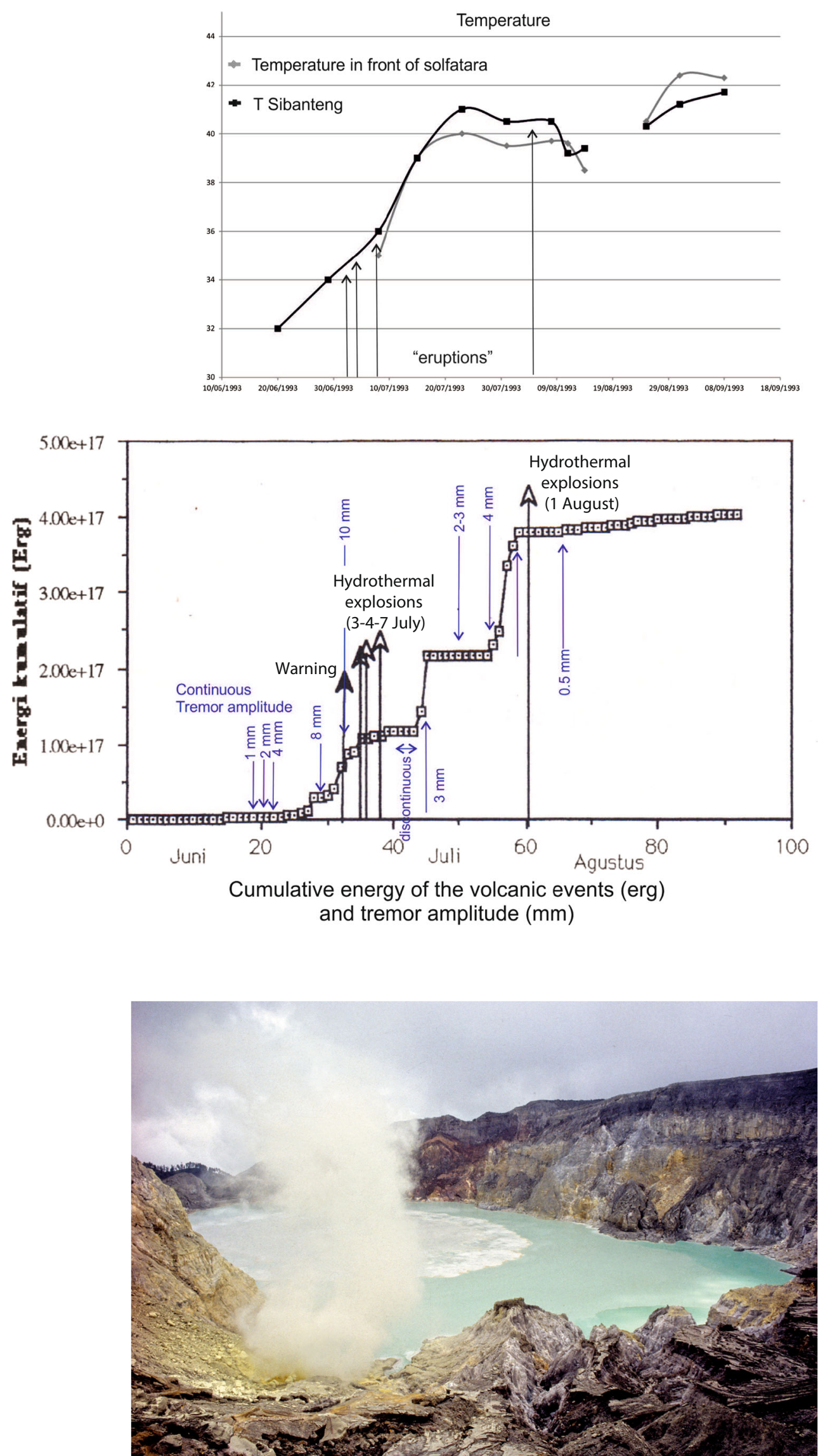

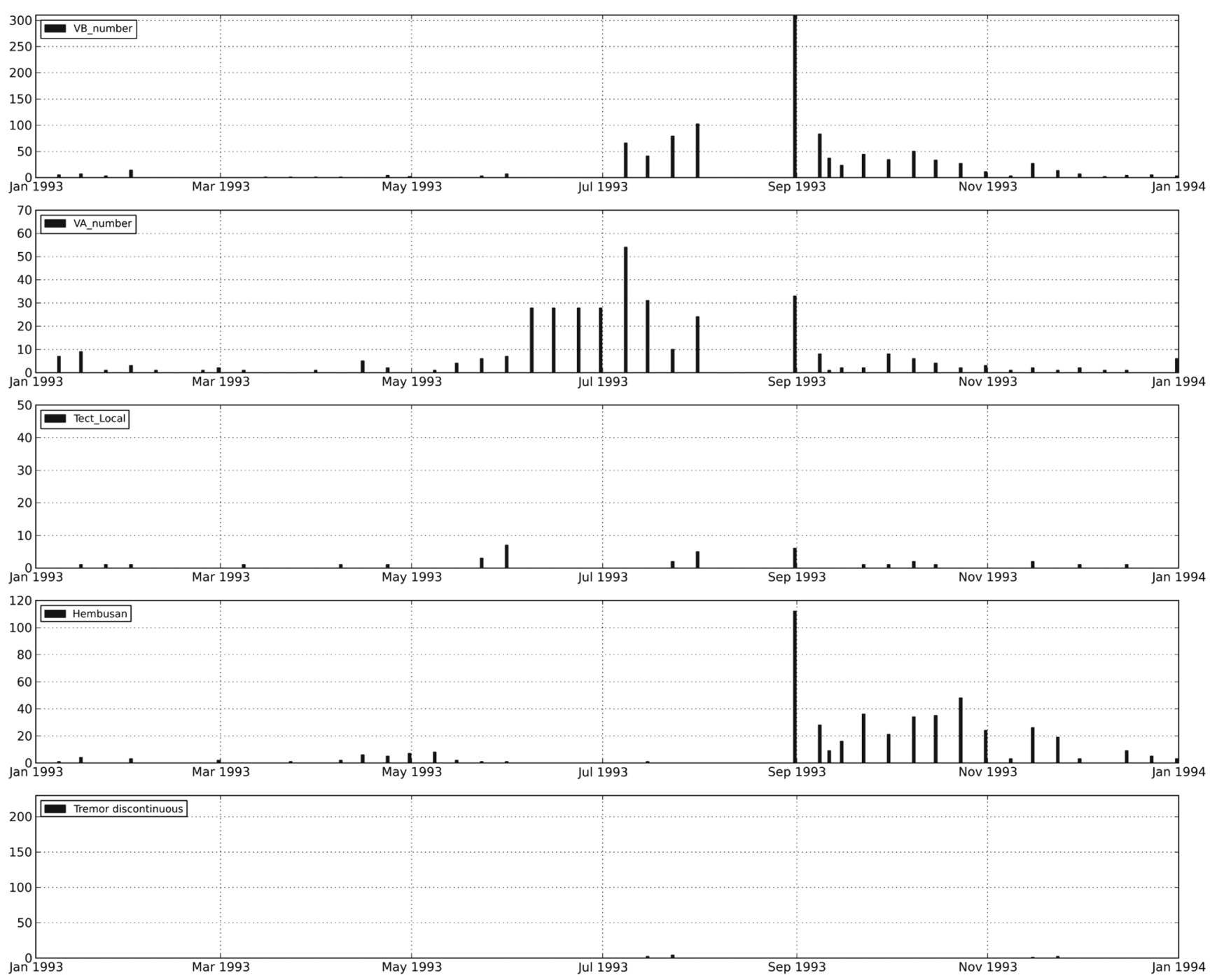

Fig. 171993 crisis. Volcano seismic events ( $y$-axis not modified compared to Fig. 14)

increase concerned VB and hembusan (Fig. 17). The temperature reached a maximum in November 1993. A striking observation also concerned the weak number of discontinuous tremor for 1993 crisis compared to 1991, while continuous tremor was recorded to a high amplitude in June and July 1993. Finally, it is worth insisting on the sharp increase in VA numbers 2 months before any sign of superficial activity.

Although the seismicity significantly decreased in 1994 (Fig. 14), an explosion was reported in BGVN (1994b) on the 3rd of February 1994 and took place on the southern part of the crater lake. Interestingly, a consequent rise of lake level of $1 \mathrm{~m}$ was reported.

In June 1997, based on BGVN (1997a), the lake became whitish together with high seismicity recorded and increased fumarolic activity. Moreover, a miner reported dizziness and headaches. Geologist Steve Mattox noted that on 29 June 1997, the area was closed to public after birds were seen falling into the water (BGVN 1997a). This occurred after a slight increase in the number of VA in May (Fig. 14). Mid-June, continuous tremor was recorded with an important amplitude (max. $30 \mathrm{~mm}$ (BGVN 1997b)) along with a high number of VB ( $\sim 300 /$ week). Lake temperature did not rise to abnormal values $\left(<40{ }^{\circ} \mathrm{C}(\mathrm{BGVN} 1997 \mathrm{~b})\right)$. The seismicity did not return to background levels until December 1997.

In fact, between 1993 and 2000, lake temperatures remained low and below values previously observed during hydrothermal activity. If we except the aforementioned crisis of 1997, the seismicity also remained below the background seismic activity until 1999: few VBs (not above 
20-30/week), hembusan ( $<10$ /week), very few VAs $(<$ $5 /$ week) and no continuous tremor.

The alert was raised in April 1999 due to an increase in seismicity. The 1999 weekly reports were taken to Jogyakarta and never came back to Kawah Ijen observatory. Luckily, a special report was published internally (Purwanto 1999). In April, the seismicity was dominated by VB and the tremor amplitude varied between 0.5 and $3 \mathrm{~mm}$. In June, the number of VB per day was close to 5 . On the 8 th of June, 11 volcanic events were recorded together with 3 hembusan events. A small explosion was reported on the 23rd of June. The seismicity remained weak. Only one volcanic event was recorded on the 27 th of June. The second explosion occurred on the 28th of June at 05.10 WIB (Western Indonesian time) 1999. A tremor of 3-5 min with a maximum amplitude of $3 \mathrm{~mm}$ at $01.18 \mathrm{WIB}$ and especially VB between 04.40 and 04.50 WIB preceded this event. An accompanying detonation was heard at the sulfur weighing site, $2 \mathrm{~km}$ from the summit, and volcanic tremor was recorded with an amplitude of 0.5-1 mm (BGVN 1999). The following week, 6-12 July, yellow-gray sulfur emissions were observed from the crater and a loud "whizz" noise was heard. The lake waters were brownish-white and sulfur spherules floating on the surface were observed. This observation related to the sulfur does not necessarily reflect an increase in activity. Thick haze prevented observations from 13th July through 23th August, but VB events and continuous tremor were recorded. When J.M. Bardintzeff visited the area, on 17th August 1999, the solfatara was strongly active and the crater filled with gas. The acid lake had a pale-green color (BGVN 1999).

Visual observations complemented the report. The color of the lake remained green, but bubbles were observed spreading evenly on the surface with a weak force. Sriwana et al. (1999) sampled the lake and the Banyu Pahit in April, May, and June 1999. We call into question the relevance of those measurements. For example, the river apparently contained 77,356 ppm of Al in June 1999 which is unlikely. We will, thus, not consider those results.

The measurements of lake temperature likely reflected superficial layers. The last measure before the explosion was made on March 1999 and was below $30{ }^{\circ} \mathrm{C}$. In July, lake temperatures were around $40{ }^{\circ} \mathrm{C}$ and thus normal. Apart from the special report, a series of graphs related to the seismicity were recovered in Kusnadi et al. (2000). The legend might be erroneous as the histograms of VAs remarkably fits the number of VBs reported above. No more relevant information can be gained from the evolution of continuous tremor. Neither the seismic, nor the visual or geochemical data allow to better understand this volcanic unrest, as the relevance of those data is highly questionable.
The 1999 unrest marked the start of a period of 5 years of unrest. Temporal variations of the seismicity are displayed in Fig. 18 and other relevant observations in Fig. 13.

Volcanic activity between 2000 and 2010

Mid-June 2000, a high number of VBs and the initiation of volcanic tremor (maximum amplitude of $4 \mathrm{~mm}$ ) were noticed. BGVN (2000) reported a small material emission that rose $25 \mathrm{~m}$ above Ijen's summit (second week of September). The number of VB remained high and continuous tremor was still noticed in October.

The number of VB increased in February 2001 lasting through the year until September. The number of VA reported in the reports we used and the one in the Table 1 of BGVN (2001a) were not similar, while the numbers of VB were roughly in agreement. Ahmad mentioned explosion earthquakes which might be the literal translation of hembusan (BGVN 2001a), but does not correspond to an explosion. Moreover, the number of hembusan we reported and the number of explosion earthquakes did not correspond. We currently have no idea of what an explosion earthquake could be related to. The appearance of discontinuous and continuous tremor (max amplitude of $3 \mathrm{~mm}$ ) was the major cause of concern. The alert level remained at 2 (on a scale of 1 to 4). Although BGVN (2001b) mentioned increased seismic activity in terms of VB and continuous tremor (and the highly suspicious explosion earthquake), the main source of worry was the high-amplitude continuous tremor.

The same remarks holds for BGVN (2002a). Apart from the continuous tremor, the number of $\mathrm{VB}$ was small until the end of April 2002. The number of VB then sharply increased (70/week compared to 10/week maximum previously). In May, three VAs were recorded. One explosion earthquake was reported (BGVN 2002a). The number of VB decreased until August, and one VA was recorded. The continuous tremor amplitude remained high (maximum $6 \mathrm{~mm}$ ). On 29 July, a small explosion was reported in BGVN (2002b). Moreover, they reported the emission of material during late July through mid-August. This was accompanied by an increase in the number of VBs (max 65/week), to a lesser extent of VAs (6/month in August), and by high continuous tremor amplitude. The activity remained above background level for the rest of the year with a peak in VB activity in October (96/week). While the number of VB significantly decreased in November, the continuous tremor amplitude culminated to $12 \mathrm{~mm}$ (BGVN 2003a). The authorities lowered the alert status in 2003 due to the decrease in the number of events.

The status was raised to 2 in October 2003 due to increased seismicity ( $\max 32 \mathrm{VB} /$ week, maximum continuous tremor amplitude of $4 \mathrm{~mm}$ ) and several VAs. We did 

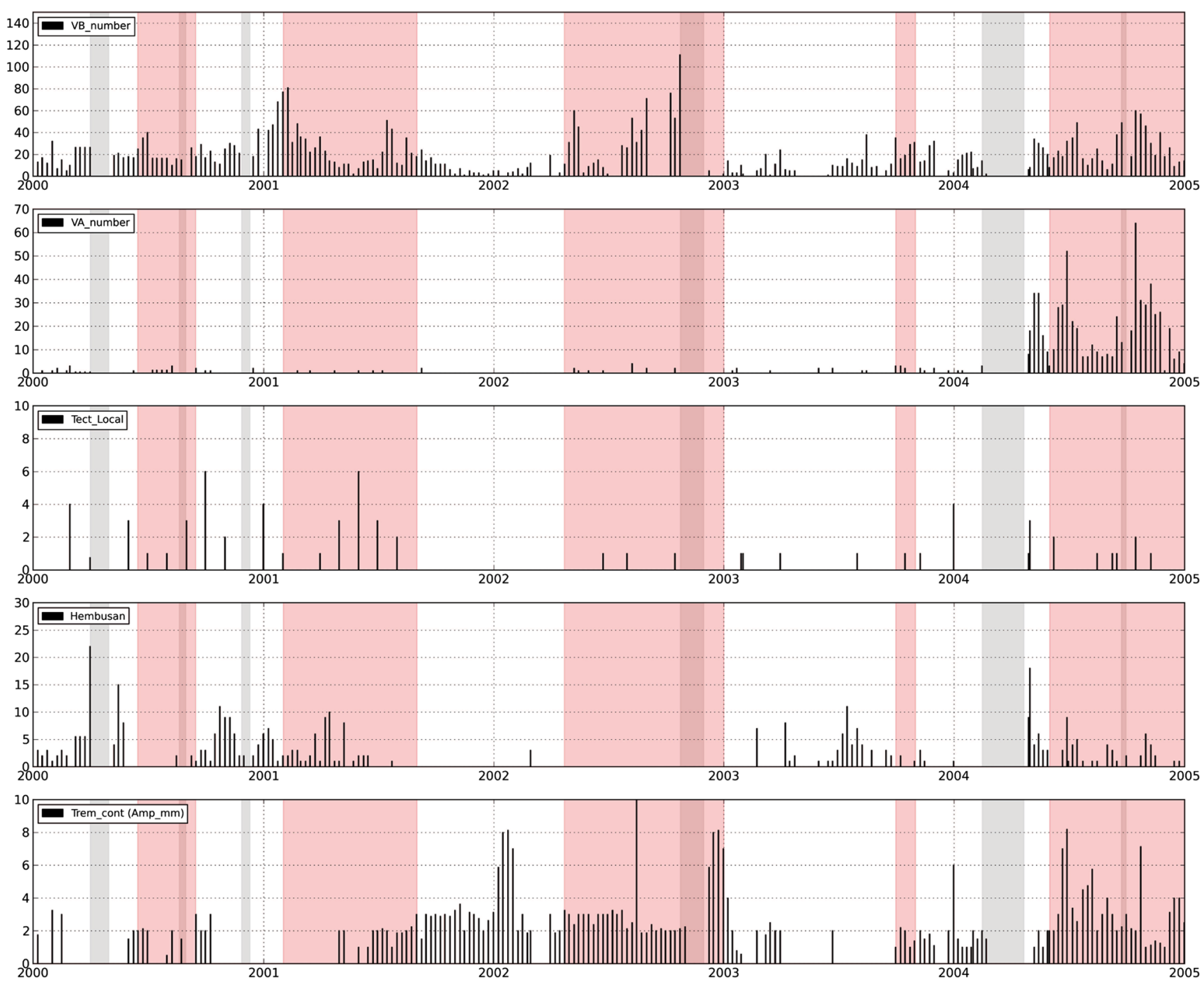

Fig. 182000 unrest. Volcano seismic events (y-axis not modified compared to Fig. 14). Light grey shadings represent a gap in the seismic data. Light red rectangles indicate approximate periods of unrest

not find the 8 VAs mentioned in BGVN (2003b) during the last week of November. BGVN (2003b) and BGVN (2003c) also reported a debatable "emission earthquake."

BGVN (2004) mentioned that the area was closed to visitors in June 2004 due to an increase of activity. Reuters agency quoted the chief of the local National Park: "There have been sulfuric rocks coming out of the edge of the crater and the fluid in it has turned from green to white and has emitted hot foam. There are also increasing tremors." We recovered a special report which precisely described the activity and complemented the usual information (Purwanto 2004).

Early May 2004, the number of VA dramatically increased to more than $30 /$ week. Tremor became continuous and VB number rose but less dramatically. Six tectonic local were detected in May. It is difficult to know whether this could have started earlier as the seismometer was not operating between mid-February and mid-April 2004.

On the 10th of June 2004, the surface of the lake rose by $0.7 \mathrm{~m}$ (Purwanto 2004). On the 16th of June, they recorded seismic events that were attributed to the continuous upwelling of bubbles in the water, without mentioning which type of earthquake it did correspond to. Based on the daily reports, we contend that it might be related to the continuous tremor which reached an amplitude of $8 \mathrm{~mm}$. Indeed, on the 19th of June, tremors were noticed with an amplitude reaching $20 \mathrm{~mm}$ while the continuous tremor maximum amplitude was of $8 \mathrm{~mm}$. Electronic distance meters $(E D M)$ measured an inflation of $12 \mathrm{~cm}$ on the 19th of June. In conclusion, between the 10th of June 2004 and the 20th of June, the seismic activity was characterized by a higher number of VA compared to 
VB and a high amplitude of continuous and discontinuous tremor. The alert was raised to 2 . It is unfortunately impossible to recover additional information although the activity was still high between October and December 2004.

The volcanic activity remained weaker for the next 6 years. During some periods (e.g., February 2008 or December 2008), the number of VB and VA rose, but the continuous tremor amplitude never exceeded $4 \mathrm{~mm}$. Canadian scientific teams (McGill and Simon Fraser universities) surveyed the area between 2006 and 2010 and published reports in BGVN $(2007,2009)$. Although from a monitoring perspective a measurement performed each year does not allow to evidence any reliable change, they did not detect any sign of activity (Mauri 2009). The only important observation concerned the appearance of a new fumarole on the flank of the escarpment bordering the mound on to the west which would suggest a westward migration of the activity (BGVN 2009).

\section{Discussion}

It is difficult to take advantage of the other data we compiled (e.g., mean and maximum amplitudes, magnitude of earthquakes) due to the randomness of some parameters for the 20 -year period. Figure 19 clearly shows that maximum amplitudes of VA were retrieved during 1993 and 2004 unrest and are well correlated with a higher number of VA. On the contrary, the mean amplitude was not higher during the unrest. In 2004, lower S-P and magnitudes (which is only based on the duration) were observed pointing to shallower events of high amplitudes. The maximum
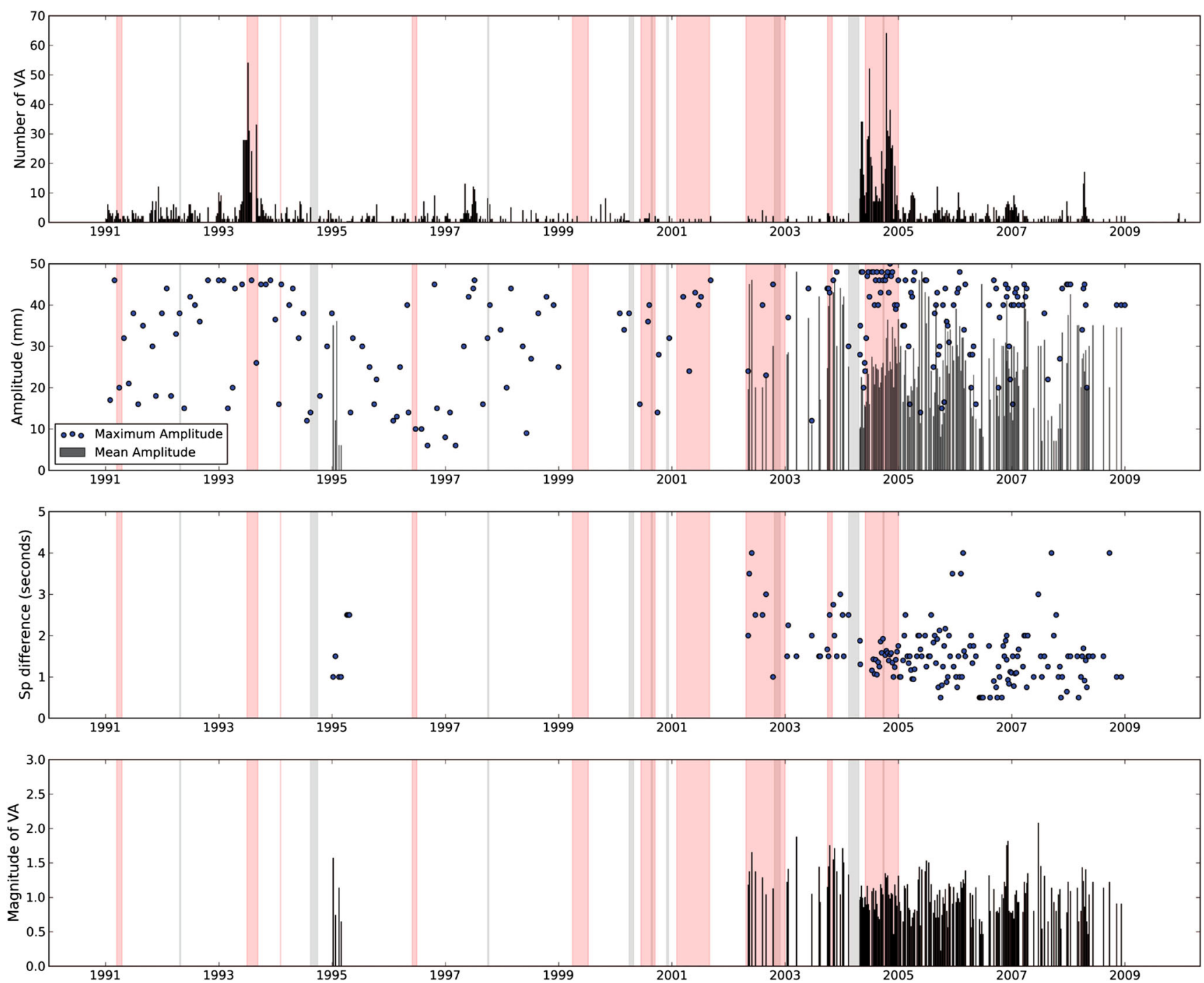

Fig. 19 VA features between 1991 and 2010. Red and grey shadings indicate unrest and gap of seismic data. The absence of points or bars in subplots 2 and 3 indicate a gap 
amplitudes for VB events were recorded in 1993 and 2004 (Fig. 20), as for VA events. Overall, maximum amplitudes were less important during the 90s compared to 2000s. Magnitudes slightly decreased since they began to be measured in 2002 .

The background seismic activity comprises VB events. Each unrest displayed different type of activity but similar patterns may be identified. From the measurements we gathered, there was no systematic correlation between the lake temperature and the superficial explosions, but high lake temperatures (over $47-48{ }^{\circ} \mathrm{C}$ ) were generally linked to volcanic unrest. It happened in 1991, 1992, 1993, 2000, 2001, 2002, and 2004. However, the lake temperatures taken after 1992 were systematically biased during the rainy season. For the last 20 years (and the last century), the unrest was characterized by upwelling of bubbles, sharp level increases, a white-colored lake and indirect observations such as workers headache and diseases or deaths of animals. Landslides and a brown-colored lake were also noticed. Those phenomena may be linked. Strong landslides have recently been recorded before the lake became brownish (in March 2012, Fig. 21) spreading from the lake shores to the center of the lake. Rocks falling from the flanks inside the lake dissolve into the lake and consequently increase the $\mathrm{pH}$ coloring the water owing to the presence of $\mathrm{Fe}^{3+}$, for example. In March 2012, the lake rapidly recovered its green color. More than $15 \mathrm{VA}$ detected in a week and/or a continuous tremor amplitude above $4 \mathrm{~mm}$ are causes of concern. Hembusan are less clearly correlated to unrest.

According to the head of the observatory who observed the volcano since the $80 \mathrm{~s}$, the strongest unrest occurred
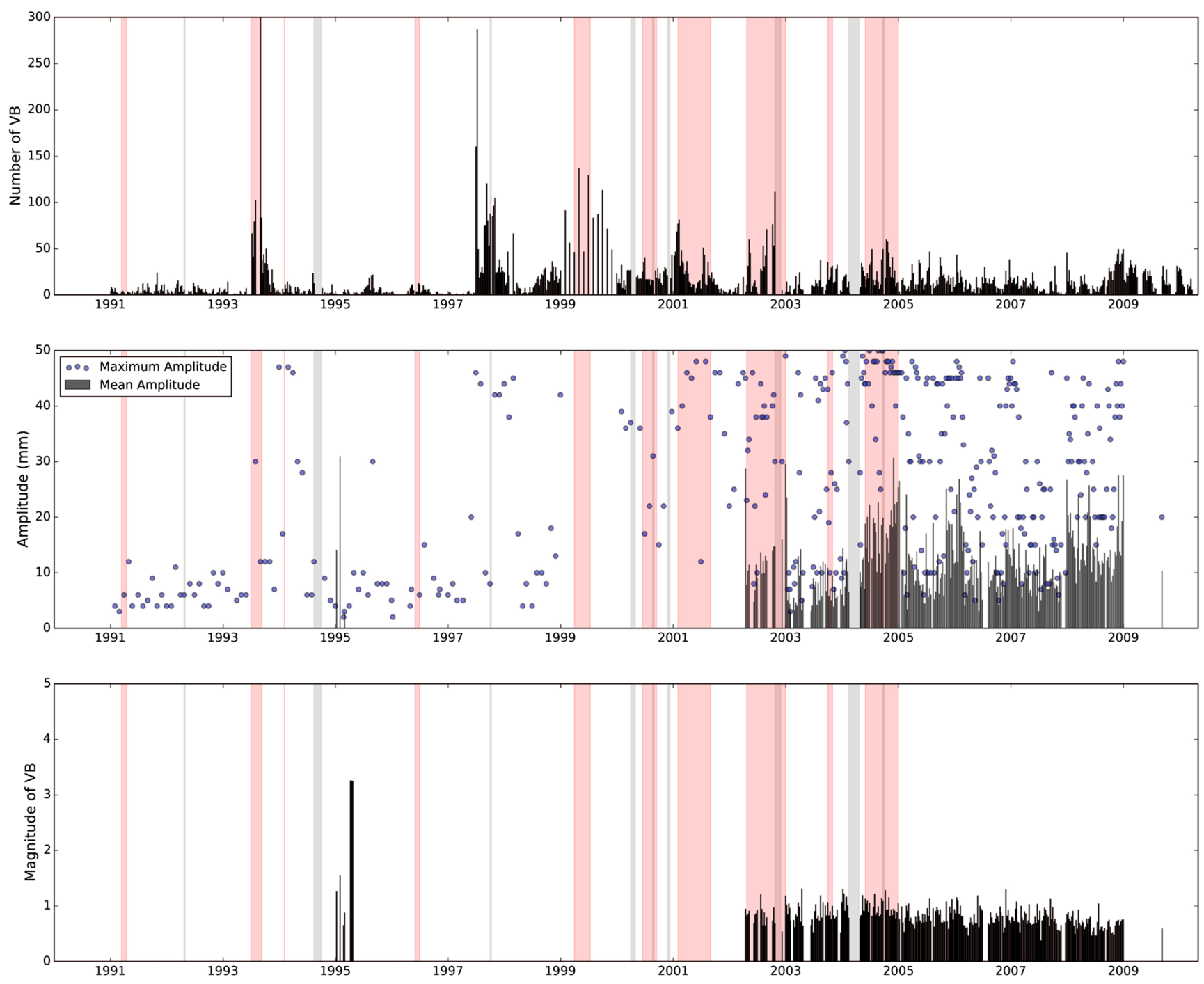

Fig. 20 VB features between 1991 and 2010. Red and grey shadings indicate unrest and gap of seismic data. The absence of points or bars in subplots 2 and 3 indicate a gap 
Fig. 21 Image acquired on the 26/03/2012 (07:58 UTC) by the closed-circuit television (CCTV) camera installed at the southern summit of the crater

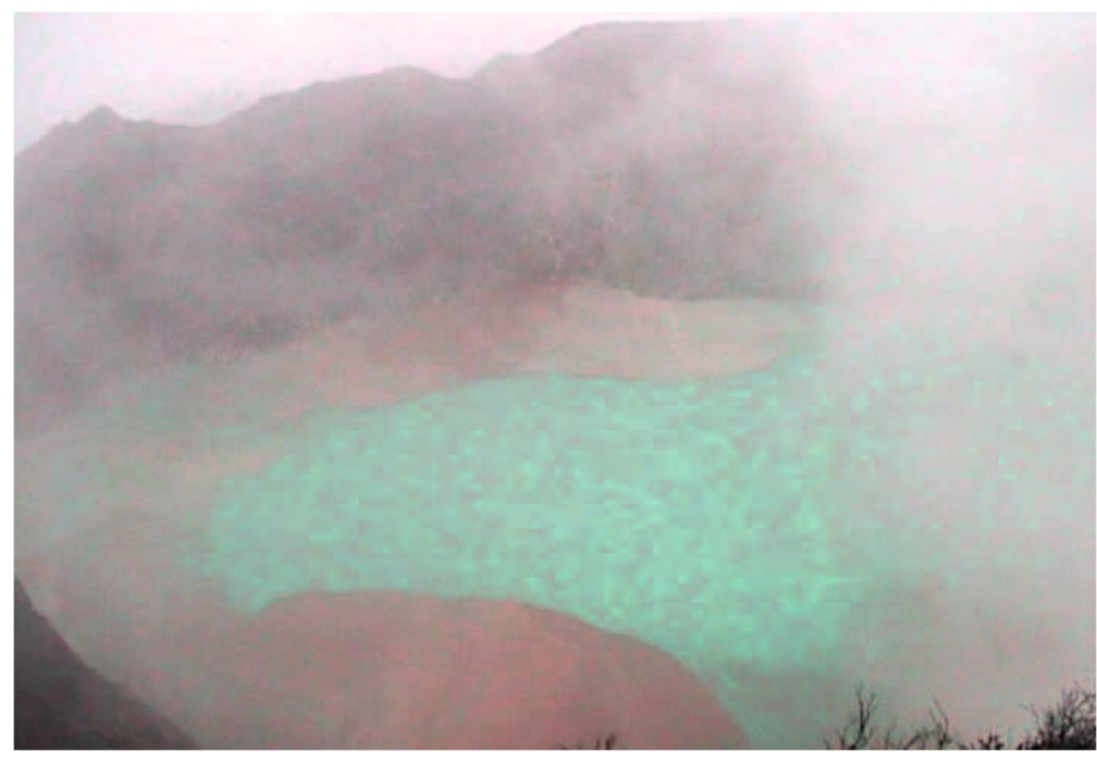

in 1993 and 2004. The latter were definitely preceded by an increase in the number of VA. It likely reflected magmatic intrusions which consequently triggered a specific seismicity originated in the hydrothermal system due to enhanced degassing. During the superficial activity, continuous and/or discontinuous tremor always reached high amplitudes. This type of seismicity (VA and tremor) constituted the key to understand Kawah Ijen volcanic activities.

The different unrest and the relevant information are summarized in Table 4.

\section{Monitoring network since 2010}

\section{Bathymetry}

Using an echo sounder, Takano et al. (2004) estimated the lake volume in 1996 to 30 millions of $\mathrm{m}^{3}$. Based on echo sounding profiling in May 2010 and July 2011, we inferred a bathymetric map using a nearest neighbor interpolator (Fig. 22). Through this map, we calculated the surface of horizontal crosscut at each $10-\mathrm{m}$-spaced elevation (i.e., $160 \mathrm{~m}, 150 \mathrm{~m}$, etc.). Then, we inferred volume between each step. The total lake volume equals 27.5 million $\mathrm{m}^{3}$. Compared to the previous studies, this is 16 million $\mathrm{m}^{3}$ less than the volume determined in 1922 ((Taverne 1923) in Takano et al. (2004)) (Table 3) and 3 million $\mathrm{m}^{3}$ less than in 1996 (Takano et al. 2004) (Table 3).

Although the level is clearly lower than a century ago, its depth decrease cannot account alone for such a decrease of volume. The pictures taken during the last century roughly corresponded to a lake level 10-15 m higher compared to the current one, while the maximum depth decreased by $50 \mathrm{~m}$. The decrease in superficial lake level would only explain 3.4 to 5.3 million $\mathrm{m}^{3}$ of the 13 missing. Takano et al. (2004) already suggested that the greatest lake volume in 1922 could have resulted from a large phreatic eruption that occurred in 1917. As no important eruptions were observed since then, the crater was probably filled by landslides and/or enhanced mineral precipitation at the lake bottom. The main morphological features evidenced by Takano et al. (2004) between 1938 and 1996 were a shifting of the most active vents from east to west. No important change in the lake morphology occurred between 1996 and 2010-2011.

\section{Network}

The location of the seismic stations is shown on Fig. 23. Colors correspond to the different sensors installed at Kawah Ijen: Red: ROB (Royal Observatory of Belgium) broadband stations / Black: ROB short period stations / Blue: short period stations (USGS-VDAP (Volcano Disaster Assistance Program) installation) / Yellow: CVGHM short period stations / Green: GEOFON (Germany) broadband station. The large map is derived from a Landsat7 image (7th band greyscale) overlaid by the colored Aster global digital elevation map (GDEM) product. Shuttle radar topography mission (SRTM) product was used to draw the contour lines. The small Google Earth map in the right corner indicates the location of Jagi station and the red circle the location of Kawah Ijen crater $(\sim 45 \mathrm{~km}$ of distance). 


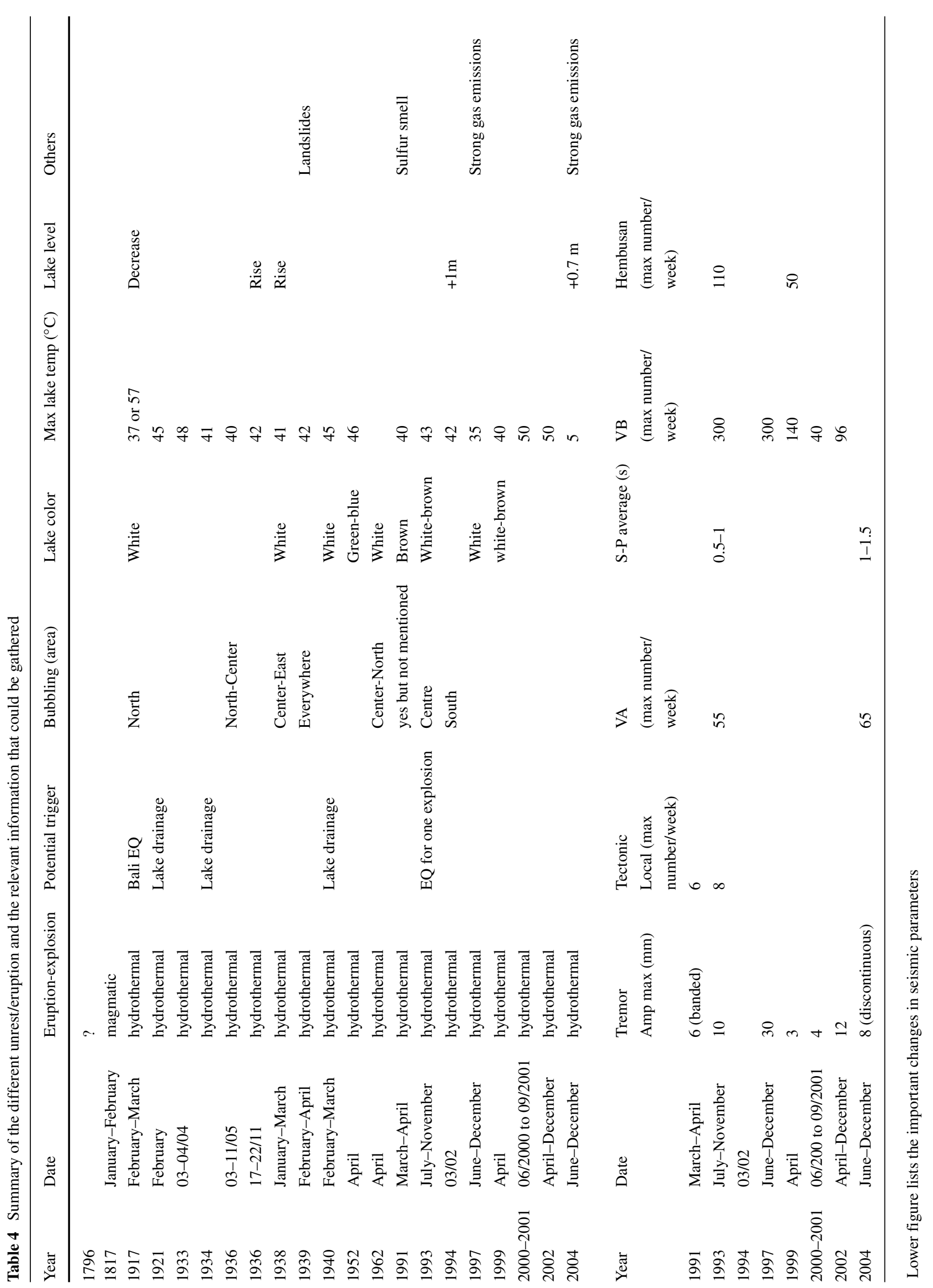


Fig. 22 Lake bathymetry based on echo sounding profiles acquired in 2010-2011 (natural neighbor interpolation)

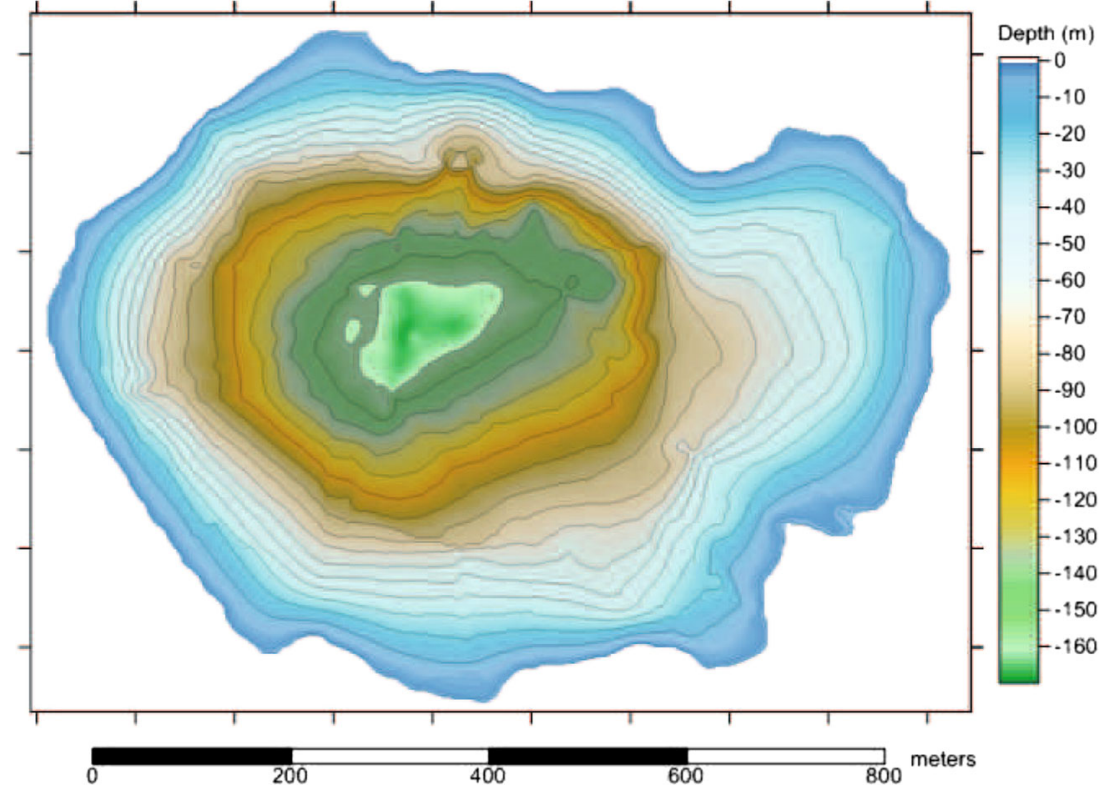

Several areas were investigated to map the most interesting sites for continuous measurements in the volcanic lake. Finally, dam location was selected for safety and convenience reasons (Fig. 3).
Towards a unified seismic classification

The availability of digital data has allowed us to revise the seismic classification. Seismic waveforms provide detailed

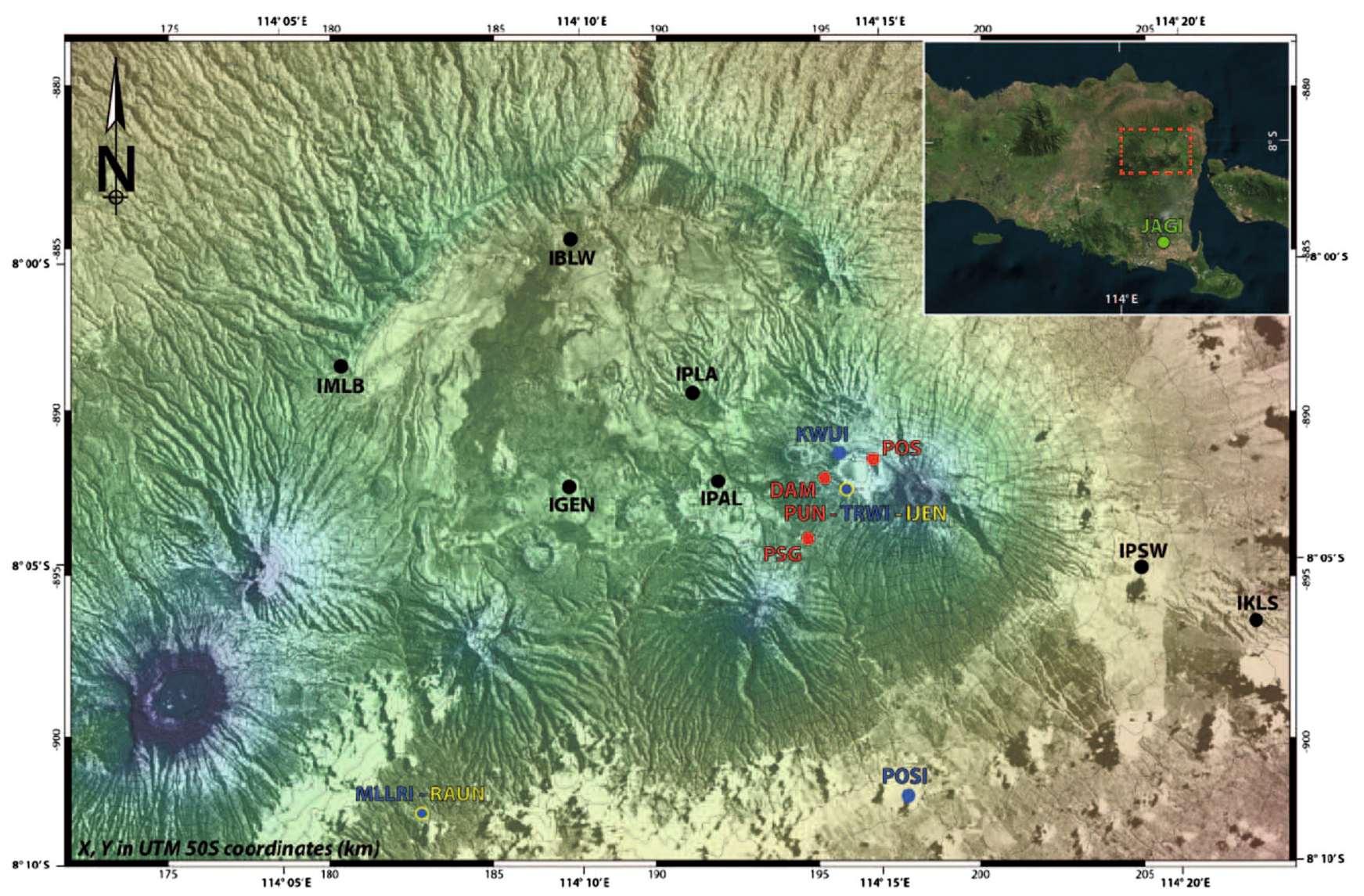

Fig. 23 Seismic network. See text for details 
information on the source and and on the path the seismic wave has traveled from the source to the seismometer, including all interfaces along which the wave has traveled, been reflected at, or transmitted to (Green and Neuberg 2006). Our classification of the seismic signals is improved by analyzing their frequency content and more specific investigations, as the frequency alone does not uniquely indicate the process (McNutt 2005). The first classification criterion remains the presence of a clear $\mathrm{S}$ wave or not.

\section{Tectonic earthquakes and tectonic local}

Tectonic earthquakes often occur in Indonesia. On the contrary, tectonic locals (Fig. 24) are rarely recorded by the seismic network, but these earthquakes certainly deserve a proper attention in a context such as Kawah Ijen caldera, not only due to the presence of the active Raung volcano, but also given the proximity of recently active volcanoes.

\section{Volcano-tectonic events}

Few volcano-tectonic earthquakes (VT or VA, following Kawah Ijen observatory classification, Fig. 24) are typically recorded by the seismic network (2/month). VTs are ordinary earthquakes occurring in the brittle rock within a volcanic edifice or in the crust. They are originated by shear failure caused by stress build-up and resulting slip on a fault plane (Chouet and Matoza 2013). Stresses may be induced by dike propagation, as indicated by propagating hypocenters and fault-plane solutions reflecting regional
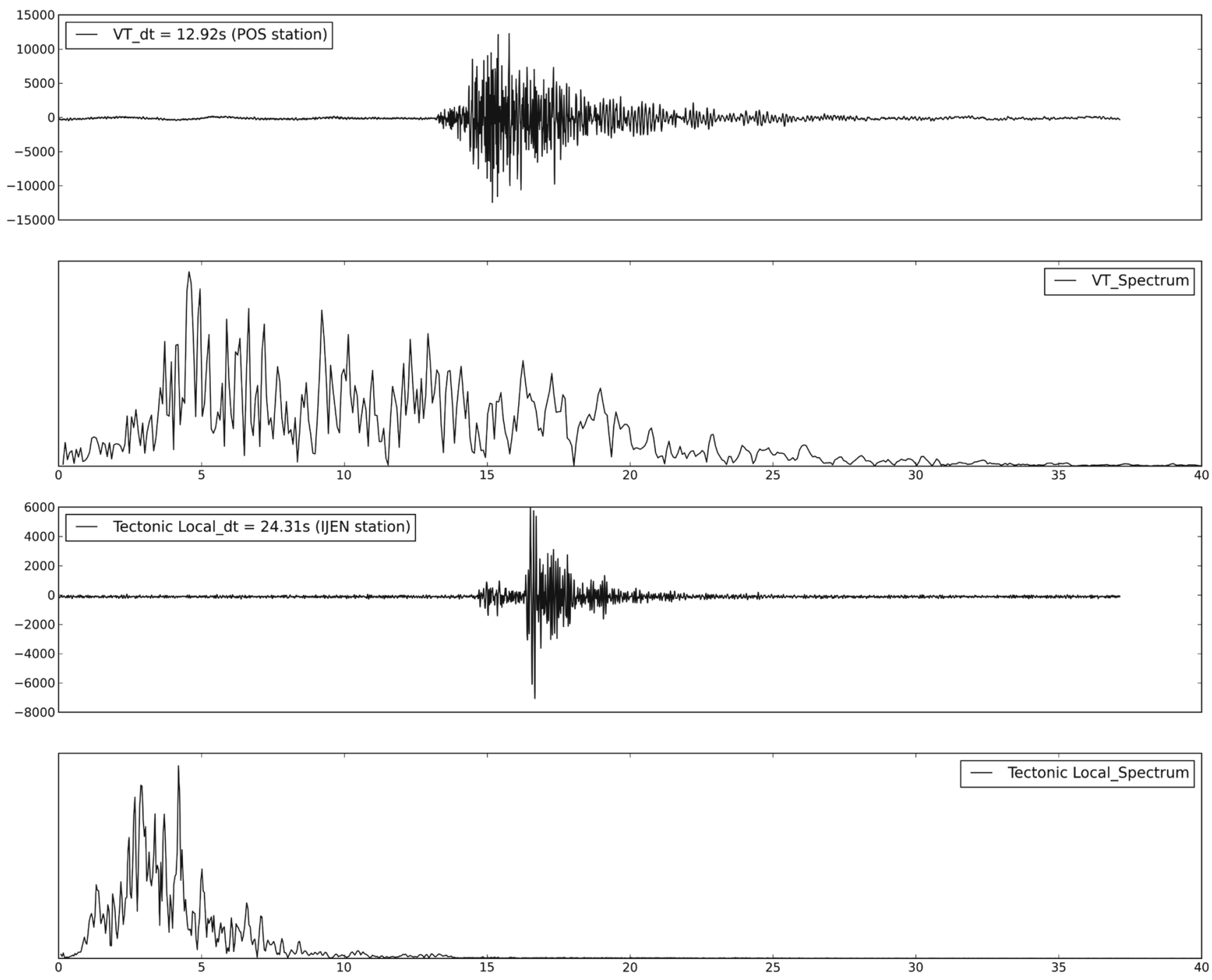

Fig. 24 Examples of VT (03/07/2011 -6 h 3 min (UTC time)) and tectonic local (21/12/2011-2 h 13 min (UTC time)) events. Velocity is in counts and frequency in Hz. Duration refers to the duration of the event only 
stresses, or stresses induced by dike inflation, indicated by randomly distributed hypocenters and fault-plane solutions with pressure axes rotated $\sim 90^{\circ} \mathrm{C}$ to regional maximum compression (Roman and Cashman 2006). They are characterized by sharp, mostly impulsive onsets of P- and S-waves, with typically broad spectra extending up to $15 \mathrm{~Hz}$ (Lahr et al. 1994). VTs recorded at Ijen are the most energetic earthquakes among the volcano-seismic events. They mostly display a duration greater than $10 \mathrm{~s}$. The difference between P- and S-wave arrivals is below $4 \mathrm{~s}(\sim 20 \mathrm{~km})$ and is measured on the vertical component. Above that threshold value, the event falls inside the tectonic local category. They differ from their tectonic counterparts only in their pattern of occurrences; they typically occur in swarms rather than mainshock-aftershock sequences (McNutt 2005). In our scheme, no constrain exist regarding the depth of the VT which violates Minakami's original definition (Minakami 1974). Therefore, the term VA is inappropriate for these events.

\section{Low-frequency events}

Low-frequency (LF) (Fig. 25) events are at the heart of volcano seismology because volcanoes generate a variety of pre-eruptive low-frequency signals (Harrington and Brodsky 2007). Most low-frequency events are thought to be caused by fluid pressurization processes such as phase separation and collapse, but also by shear failure, tensile failure, or nonlinear flow processes that occur at very shallow depths for which attenuation and path effects play an important role (McNutt 2005). Contrarily to VT earthquakes which provide information on the solid state only,
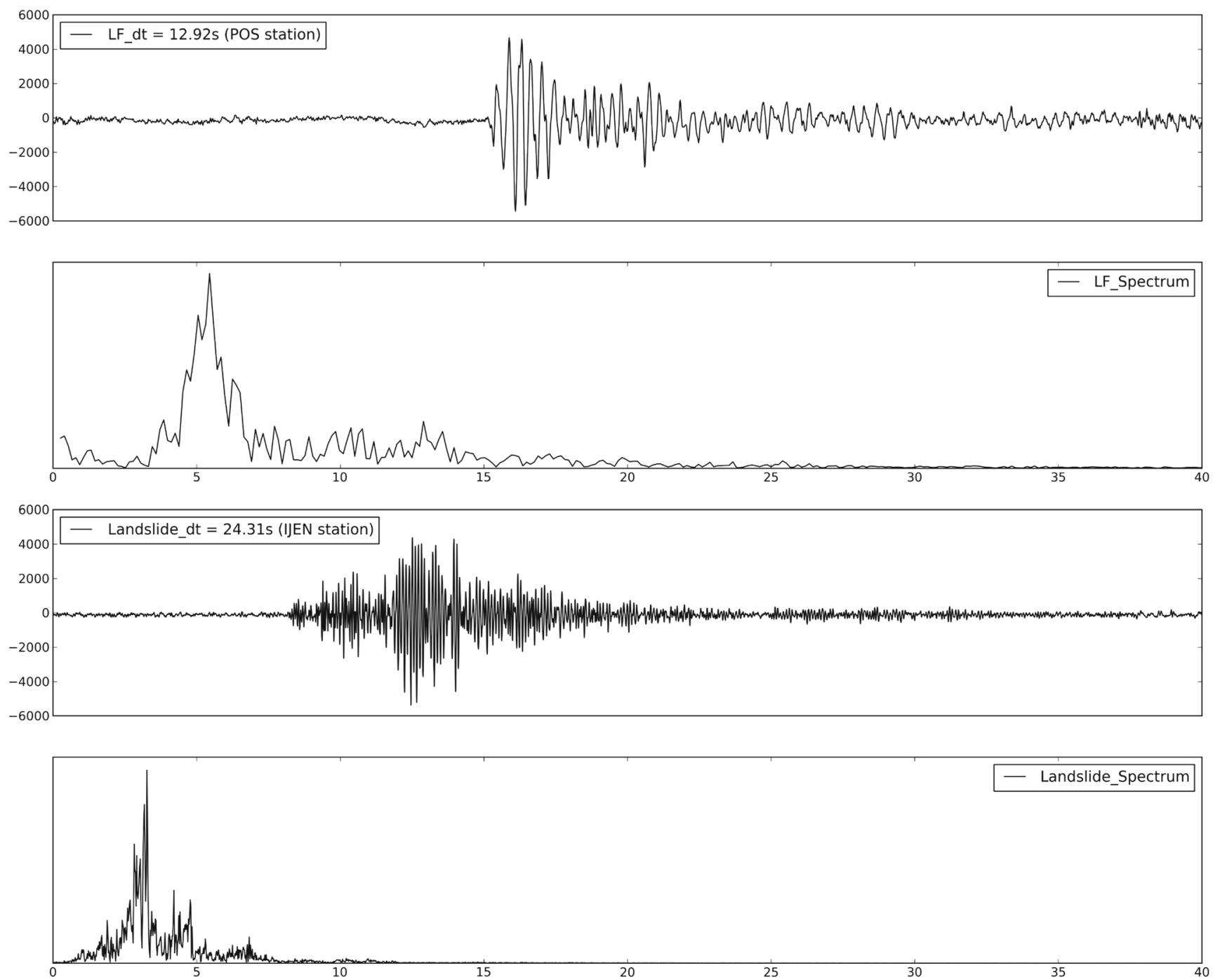

Fig. 25 Examples of LF (14/12/2010 - 18 h 48 (UTC time)) and landslide (14/12/2011 - 10 h 16 (UTC time)) events. Velocity is in counts and frequency in Hz. Duration refers to the duration of the event only 
LF may be initiated by a small earthquakes adjacent to a conduit, but also by a flow transient or pressure fluctuation within a conduit, gas bubbles expanding on contracting, a shock wave from choked flow, or other causes. They therefore provide direct windows into the state of volcanic fluids Kumagai et al. (2002). This seismicity therefore also occurs at geysers (Kedar et al. 1996) and geothermal areas (Iwamura and Kaneshima 2005).

Kawah Ijen background seismicity is characterized by low-frequency events $\left(\mathrm{f}_{0}<5-6 \mathrm{~Hz}\right.$ depending on the site, where $\mathrm{f}_{0}$ is the dominant frequency) which lack identifiable $\mathrm{S}$-wave arrivals. These events are short duration signals with an emergent P-wave onset. They also generally do not exhibit a clearly dominant spectral peak. A wide variety of sub-classes might be evidenced using spectral features. For instance, a spectrogram of a particular event can reveal a high-frequency onset and lower-frequency coda (Fig. 26). The opposite was also sometimes evidenced.

Hybrid earthquake Some earthquakes share attributes of both high- and low-frequency events (Fig. 26). Hybrid earthquakes usually refer to a long-period event (LP, see below for the description) with a pronounced highfrequency onset (Chouet and Matoza 2013). In this study, they simply reflect a subclass of LF earthquakes which presents a distinct frequency by comparing the onset and coda of a single event. Hybrid earthquakes are not part of the Indonesian classification scheme. However, during the 2011-2012 crises and thanks to the use of SWARM software (http://volcanoes.usgs.gov/software/swarm/), a few events were already classified as hybrid by CVGHM staff. It is thought that such events represent a mixture of processes, such as an earthquake occurring adjacent to a fluid-filled cavity and setting it into oscillation (Chouet 1992). Others suggest that hybrids are shallower than LF events and thus preserve most of their high-frequency energy, which is attenuated for deeper events (Neuberg et al. 1998). Finally, Harrington and Brodsky (2007) provide seismological evidence for brittle failure as a major process in dome building and suggest that hybrids should not be used as direct indicators of fluids. The low-frequency content of these earthquakes can result from low rupture velocities combined with strong path effects due to their shallow sources.

LP LP (0.5-5 Hz) (Fig. 27) are transients volumetric signals consisting of a brief broadband onset, followed by a coda of decaying harmonic oscillations containing pronounced spectral peaks that are independent of azimuth and distance to the source (Chouet 1996). They are attributed to the resonance of fluid-filled cracks or conduits induced by pressure transients in the fluid (e.g., Chouet
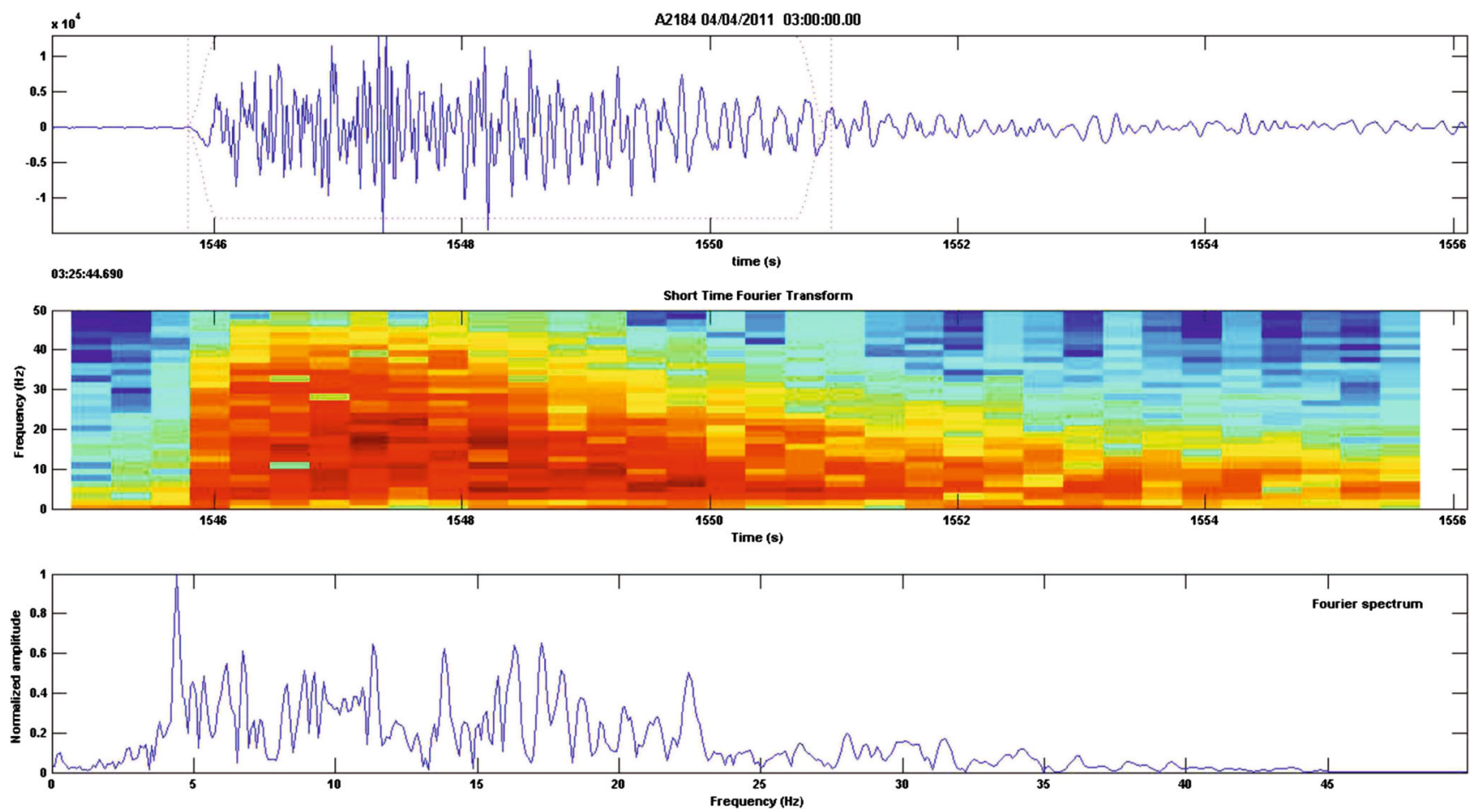

Fig. 26 Example of hybrid earthquake (04/04/2011-3 h 25 (UTC time)) processed with Seismo-volcanalysis software (Lesage 2009). Velocity is in counts and frequency in $\mathrm{Hz}$ 

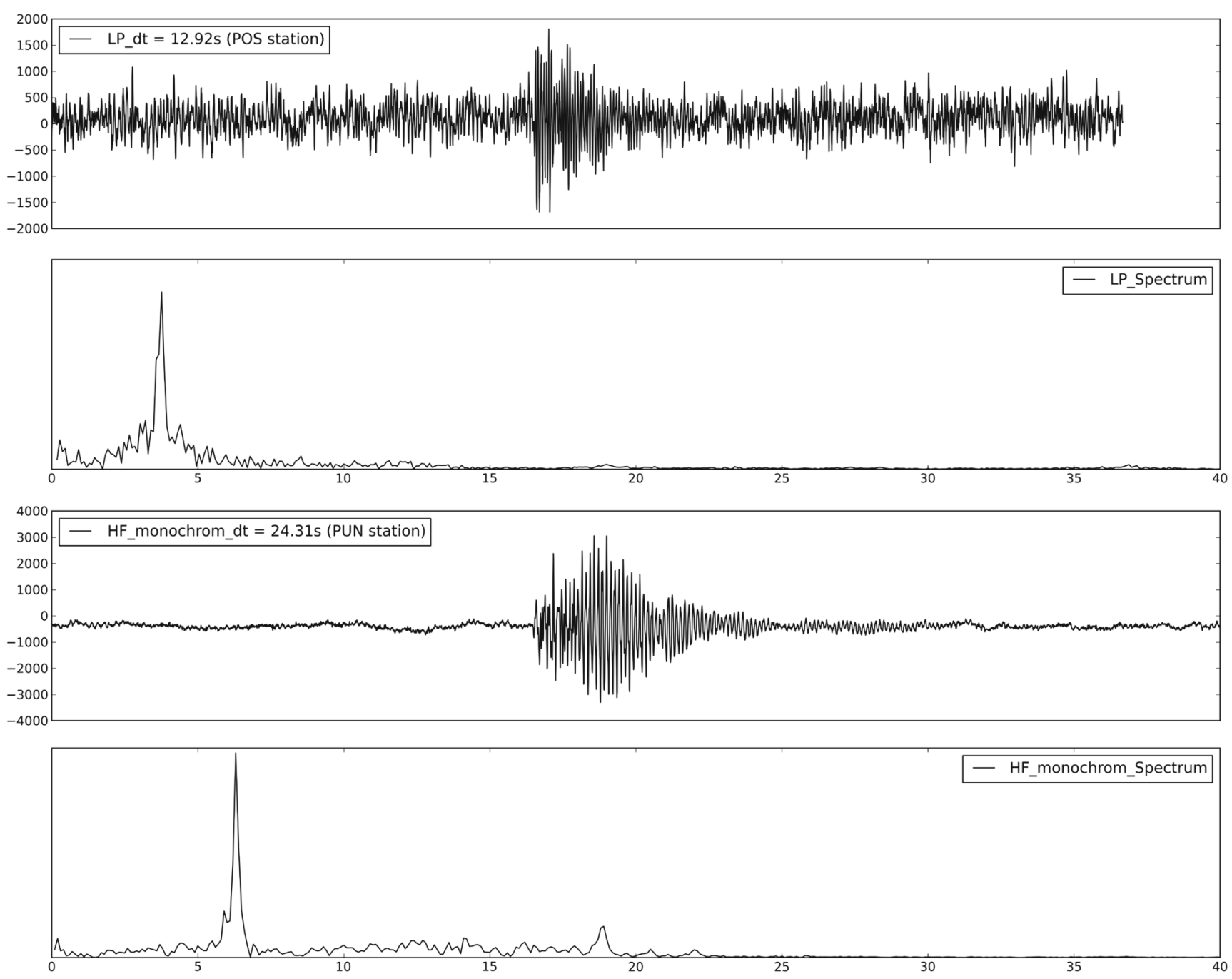

Fig. 27 Examples of LP (08/07/2010 - 8 h 41 (UTC time)) and HF monochromatic (01/10/2011-10 h 4 (UTC time)) events. Velocity is in counts and frequency in Hz. Duration refers to the duration of the event only

1996). Other physical processes are still able to trigger LP events. For example, Johnson et al. (2008) observed LP synchronized with eruptive dome inflations suggesting that conduit magma or magma pads may play a part in generating long-period earthquakes at silicic volcanic systems.

Few LPs were detected in Kawah Ijen before 20112012 crises. The investigation of this type of seismicity revealed that they resemble monochromatic tremor signals (see below), but have a shorter duration.

\section{High-frequency events}

The analysis of some seismic events revealed more spectral energy above $5 \mathrm{~Hz}$, sometimes $10 \mathrm{~Hz}$, than below 5 or $6 \mathrm{~Hz}$.
Although their spectral content is similar to VT events, their waveforms are not and lack a clear S-wave arrival. They were termed high frequency.

\section{Hembusan}

The origin of those signals is being part of the Indonesian seismic myth. Their waveform are less emergent than LFs and less impulsive than VTs, no clear S wave arrival can be distinguished, and they have spectral energies distributed in a wide frequency range (Fig. 28). Our Indonesian colleagues attribute the hembusan to shallow degassing. This stems from observations made at different Indonesian volcanoes in which fumarolic fields are present. The literal translation of "hembusan" is "blast." 

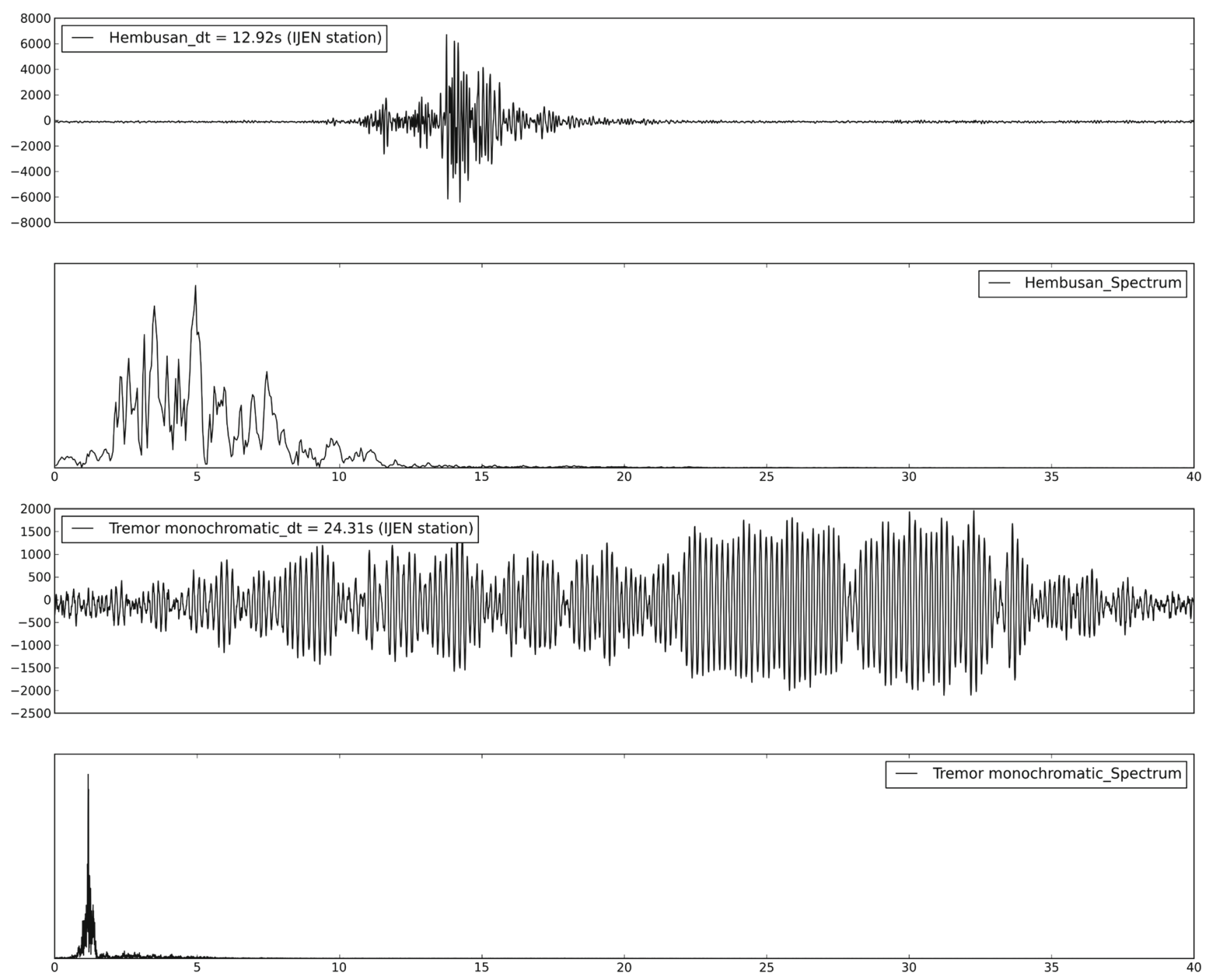

Fig. 28 Examples of Hembusan (16/01/2012-18 h 36 (UTC time)) and tremor monochromatic (05/03/2012-23 h 52 (UTC time)) events. Velocity is in counts and frequency in Hz. Duration refers to the duration of the event only

\section{Longer duration signals}

Tremor Tremor is a prominent feature of Kawah Ijen seismic activity. Volcanic tremor is a continuous signal (with duration ranging from minutes to day or longer) with dominant frequencies between 1 and $5 \mathrm{~Hz}$. The frequency content do not specifically indicate the source process, as it may be attributed either to source or path/attenuation effects due to the propagation of the waves through strongly heterogeneous volcanic structures (Konstantinou and Schlindwein 2003). Moreover, their emergent waveform does not facilitate their location. It is therefore extremely complicated to identify the physical mechanism for the source of tremor, as for LF events, because of the interplay between different material of different physical properties: magmatic/hydrothermal fluids and the surrounding bedrock. A distinction still exists between harmonic and spasmodic tremor. Spasmodic tremor is a higher-frequency, pulsating, irregular signal. Harmonic tremor is a low-frequency often single-frequency sine wave with smoothly varying amplitude; or sometimes, it consists of a fundamental frequency with many overtones (McNutt 2005).

Monochromatic tremor Some specific tremor was recorded during volcanic crises. It appears as monochromatic (the dominant frequency represents $80-90 \%$ of the spectral amplitude) at Kawah Ijen reference station because of the strong analog band-pass filter (Fig. 28). Depending on the seismic station, other spectral peaks may be identified but their spectral amplitudes are extremely weak (less than $20 \%$ ). For this reason, we named those events monochromatic tremor (MT). The latter events were only recorded 
during the 2011-2012 crises. No typical duration exists. On the contrary, the main spectral peak is extremely stable with time $\left(\mathrm{f}_{0} \sim 1.3 \mathrm{~Hz}\right.$ ). The fact that they were only detected during the crises and the remarkable stability of the dominant frequency peak makes them particularly important to monitor.

Results

\section{Seismic activity}

May 2010-October 2011 Many VTs were recorded between July and October 2010 (Fig. 29). The most energetic VTs usually followed a gap in seismic events. This period ended with the record of a few MTs tremor early October 2010. After this period, the activity got back to quiet level and a dominance of LF events. A smaller swarm of VTs was detected in February (11-22 of February 2011) (Fig. 29). A few but energetic VTs also hit the volcano on March 21st, May 21st, and July 3rd.

October 2011-August 2012 A seismic unrest already started in October 2011 with many VTs and LFs (Fig. 29). VT activity culminated in mid-December 2011, and some earthquakes were felt by the sulfur miners. A week later, monochromatic tremor (MT) and LP started to be recorded (Fig. 29). These events subsisted until mid-January 2012. The activity strongly decreased after this date. However, in February 2012, several MTs were recorded together with LF events. Few VTs, by contrast, were detected. This activity intensified until mid-March 2012. After this period, the activity diminished until July 2012 which was characterized

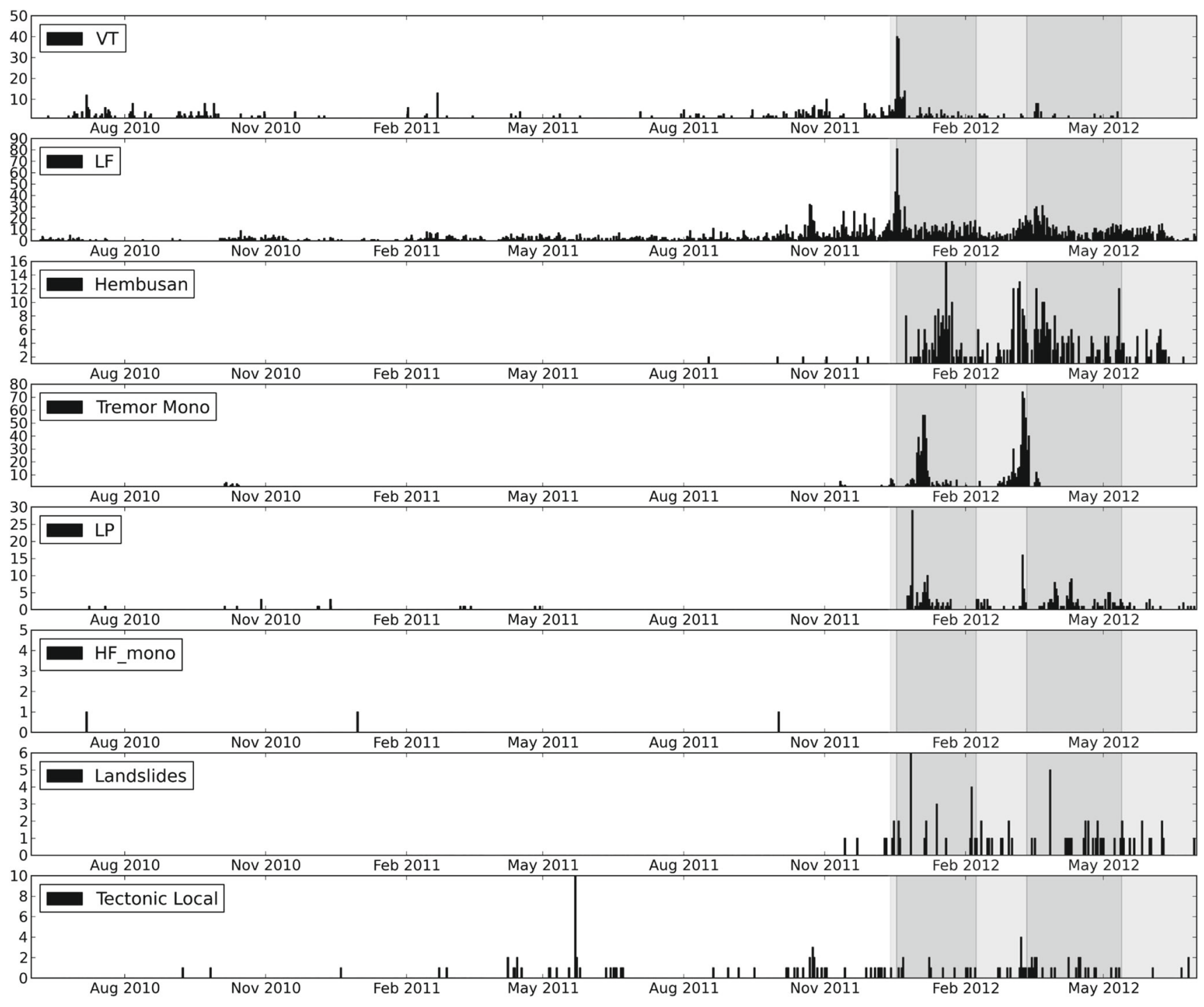

Fig. 29 Number of events per day since the new monitoring network is established. Crises are figured using light grey and darker grey rectangles (alert 2 and 3 , respectively) 
by a high record of LFs. This crisis is studied in details in (Caudron et al. 2014).

\section{Volcanic lake monitoring}

Figure 30 portrays the lake temperature evolution between May 2010 and July 2012. The isolated points on the figure (small black circles, after January 2012 in Fig. 30b) represent data downloads by CVGHM observers who started to use our sensor for their weekly monitoring after January 2012. An important aspect of this graph concerns the presence of rain periods during the dry season of 2010 due to $\mathrm{El}$ Niño phenomenon (Kim et al. 2011) (Fig. 30a).

Both the temperature and level recordings followed the same trend: they started to rise mid-December 2010,
2 months after the first rainfalls and reached their maximum early May, then decreased (Fig. 30b, c). Based on the results evidenced from the historical reports and database, this is the common annual trend. CVGHM temperatures were in agreement with our measurements until January 2011 (Fig. 30b). When the level started to rise, their measurements did not reflect the "real" temperature of the lake. The comparisons between our recordings and the measurements performed by CVGHM staff corroborate the previous conclusion made using historical data: temperatures in surface were systematically biased during rainy seasons. The sudden increase of temperature in May 2011 also suggests that the lake might be less homogeneous than previously thought, even at depth.

a

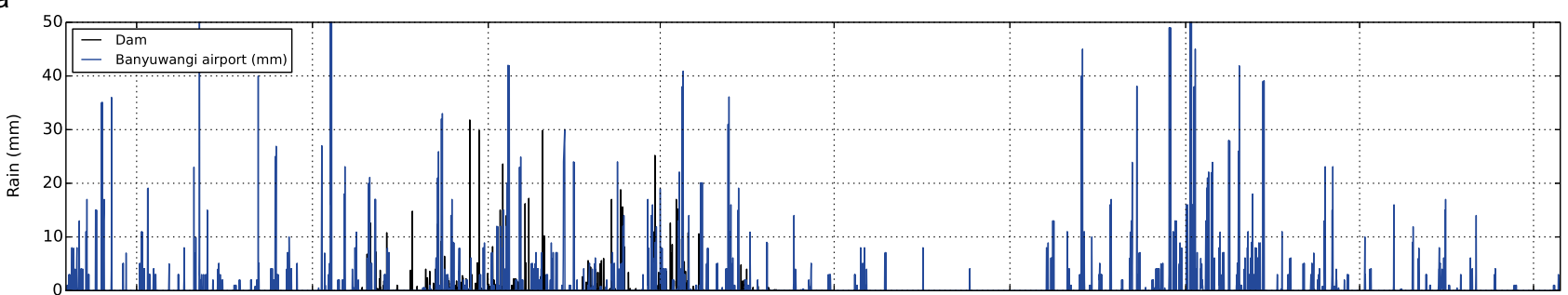

b

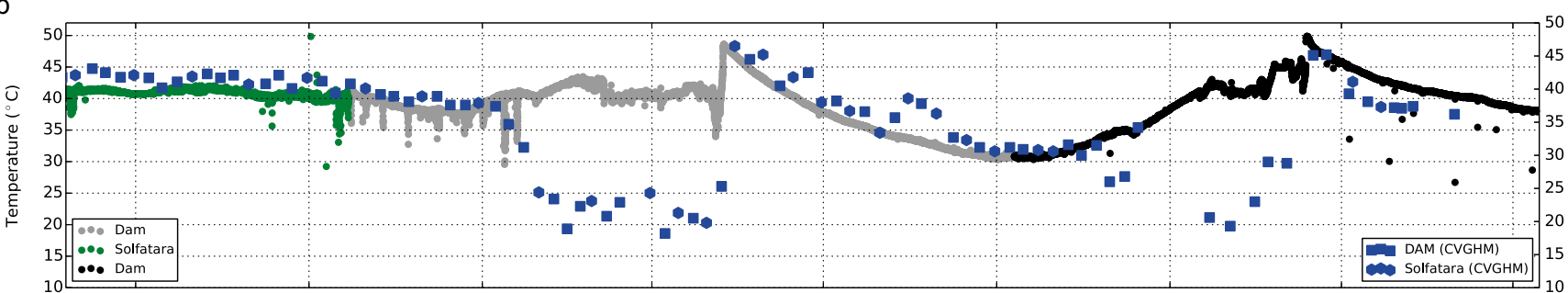

C

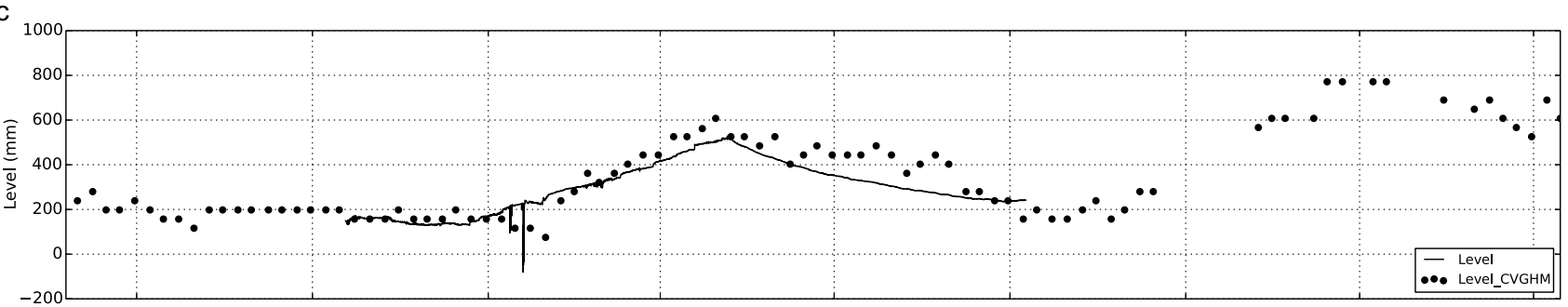

d

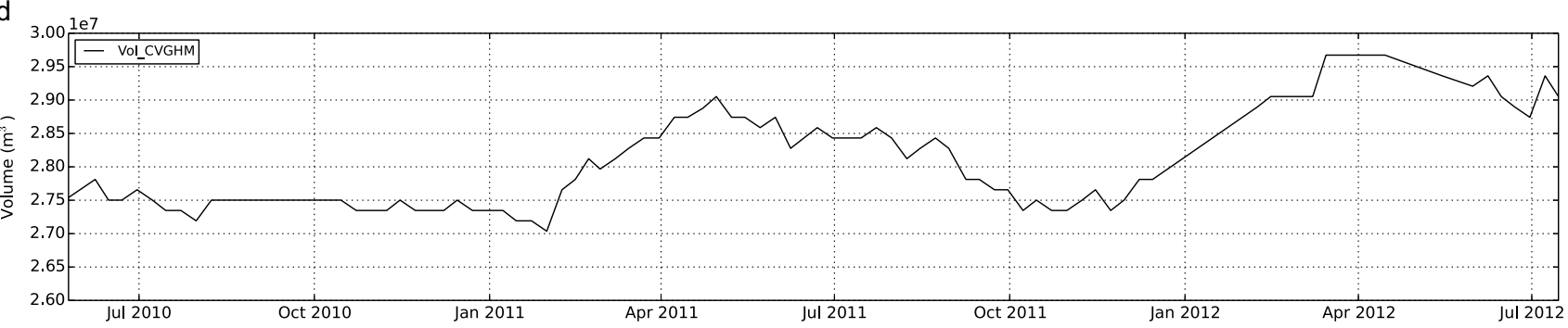

Fig. 30 Lake parameters for the period 05/2010-07/2012 / a Rain in the crater and at Banyuwangi airport (sum/day) / b Lake temperatures

data) / $c$ Lake level (1 sample/h and 1 sample/week for CVGHM data) at different locations (1 sample/h and 1 sample/week for CVGHM 
The temperature decreased by $17^{\circ} \mathrm{C}$ until mid-October 2011 and started to rise with a gradient similar to the previous year (Fig. 30b). The temperature stabilized between the 4th and 13th of December 2011. Finally, it sharply re-increased on the 14th for 1 month. After relatively constant temperatures, the temperature pattern is not stable anymore and is affected by sharp drops and increases until the 17th of March. This period coincides with a strong unrest evidenced by the seismometers (Caudron et al. 2014).

Based on echo sounding profiling carried out in June 2010 and July 2011, we estimate the total lake volume to 27.5 million $\mathrm{m}^{3}$. We tried to relate lake level measurements to volume changes (Fig. 30d). After a calibration of the data that were acquired punctually by CVGHM (using a graduated wood stick) with our high performance device (Troll 500 sensor, 1 measurement/30 min, recording between November 2010 and October 2011), we automatically derived the fluctuations of the lake volumes from surface lake level measurements by using the volume determined from the bathymetrical map. We calculated the volume considering that the level fluctuations only affect the upper $10 \mathrm{~m}$ of the lake. By using the volume determined from the bathymetrical map, we can estimate the changes of volume from our sensor recordings and CVGHM measurements (Fig. 30d).

\section{Future perspectives and conclusions}

The review of the historical volcanic activities that occurred for the two last centuries at Kawah Ijen is essential to understand the crises/eruptions that may occur in the future, but also to better monitor the volcanic system. This has permitted us to identify problems in the monitoring system (e.g., lake temperatures) and to correct them within the new monitoring scheme. We have improved our knowledge of the unrest that characterized the volcano in the past and have constructed a database of the lake and seismic parameters that are, respectively, weekly and continuously monitored since 1991. While small crises were triggered by regional earthquakes or drainage of lake waters, the strongest ones were usually preceded by an increase in the number of volcano tectonic earthquakes. The superficial visual manifestations of the unrest have often consisted in increased gaseous emissions (e.g., large bubbles at the lake surface forming "tumescence"), enhanced lake convection (i.e., white lake color), and have mostly been captured by the instruments as continuous/discontinuous seismic tremor and fast increases of lake temperature and levels. A key question at Kawah Ijen still remains to understand why a volcanic unrest do not end up as an eruption. The current monitoring network will

provide more parameters to understand a volcanic crisis and to address this question.

Acknowledgments We wish to thank VDAP group for fruitful discussions. C. Caudron warmly thanks C. Newhall and P. Tapponnier for their help related to Bali 1917 earthquake. We thank Patrizia Battisti for her help in encoding the historical data. Delphine Gilson is acknowledged for her patience in capturing all those documents in a digital format. Thanks to Christina Widiwijayanti, historical data are now available to the scientific community. We are extremely grateful to CVGHM support on the field and in the library, and particularly to the observers of Kawah Ijen, Pak Heri and Pak Parjan. This work is partly funded by a Belgian federal science policy Action 2 grant (WI/33/J02). All the data are available through Wovodat (http://www.wovodat.org/). This paper benefited from LATEX and Matplotlib (Hunter 2007). The authors are really grateful to he reviewers, D. Rouwet and R.W. Henley, for their very constructive and encouraging reviews, as well as the editors G. Giordano and J.D.L. White.

Open Access This article is distributed under the terms of the Creative Commons Attribution License which permits any use, distribution, and reproduction in any medium, provided the original author(s) and the source are credited.

\section{Glossary and abbreviations}

Hembusan

Rumbling

Seepage

Seiche

Spherule

Sluice

Tremor Harmonik

Tumescence

BGVN

CCTV

CVGHM

EDM

GDEM

LF

LP
Blast in Indonesian language, refers to a seismic event attributed to degassing. Continuous deep, resonant sound.

Slow escape of a liquid or gas through porous material or small holes.

A standing wave oscillating in an enclosed or partially enclosed body of water.

Small sphere or spherical body (of sulfur in this case).

Water channel controlled at its head by a gate (from the Dutch 'sluis').

Sustained vibration $(>30 \quad s \quad$ of duration) characterized by monochromatic/harmonic spectral peaks, refers to a seismic event.

The swelling of certain substances when heated, often accompanied by the escape of water vapor.

Bulletin of Global Volcanism Network. Closed-circuit television camera. Center for Volcanology and Geological Hazard Mitigation (formerly VSI). Electronic distance meters. Global digital elevation map. Low frequency, refers to a seismic event. Long period, refers to a seismic event. 
MT Monochromatic tremor, refers to a seismic event.

ROB Royal Observatory of Brussels.

SRTM Shuttle radar topography mission.

UN United Nation.

USGS U.S. Geological Survey.

VA

VB

VDAP

VSI

VT

WIB
Volcanic A, refers to a seismic event.

Volcanic B, refers to a seismic event.

Volcano disaster assistance program.

Volcanological survey of Indonesia.

Volcano tectonic.

Western Indonesian Time.

\section{References}

Berlo K. (2001) The magmatic evolution of the Ijen caldera, East Java, Indonesia, Master's thesis, Utrecht University

BGVN (1994a) Kawah Ijen. Bull Global Volcanism Netw 19:05

BGVN (1994b) Kawah Ijen. Bull Global Volcanism Netw 19:07

BGVN (1997a) Kawah Ijen. Bull Global Volcanism Netw 22:06

BGVN (1997b) Kawah Ijen. Bull Global Volcanism Netw 22:08

BGVN (1999) Kawah Ijen. Bull Global Volcanism Netw 24:09

BGVN (2000) Kawah Ijen. Bull Global Volcanism Netw 25:10

BGVN (2001a) Kawah Ijen. Bull Global Volcanism Netw 26:09

BGVN (2001b) Kawah Ijen. Bull Global Volcanism Netw 26:12

BGVN (2002a) Kawah Ijen. Bull Global Volcanism Netw 27:04

BGVN (2002b) Kawah Ijen. Bull Global Volcanism Netw 27:08

BGVN (2003a) Kawah Ijen. Bull Global Volcanism Netw 28:03

BGVN (2003b) Kawah Ijen. Bull Global Volcanism Netw 28:12

BGVN (2003c) Kawah Ijen. Bull Global Volcanism Netw 28:10

BGVN (2004) Kawah Ijen. Bull Global Volcanism Netw 29:11

BGVN (2007) Kawah Ijen. Bull Global Volcanism Netw 32:09

BGVN (2009) Kawah Ijen. Bull Global Volcanism Netw 34:02

BGVN (2012) Kawah Ijen. Bull Global Volcanism Netw 37:07

Bosch (1858) Uitbarstingen der vulkanen Idjin en Raun (Banjoewangi). In: Tijdschrift voor Indische Taal-, Land- en Volkenkunde, vol 7, pp. 265-286

Braak C (1920) Het klimaat van den Idjen. Vol. V, BataviaWeltevreden, Koninklijke Natuurkundige Vereeniging Monografie, bij G. Kolff and Co., Weltevreden- Batavia

Carn SA (1999) Application of synthetic aperture radar (SAR) imagery to volcano mapping in the humid tropics: a case study in East Java, Indonesia. Bull. Volcanol. 61(1):92-105

Caron M (1914). Tech. rep., Bandung

Caudron C, Mazot A, Bernard A (2012) Carbon dioxide dynamics in Kelud volcanic lake. J Geophys. Res. 117(B5). doi:10.1029/2011JB008806

Caudron C, Lecocq T, Syahbana D, Watlet A, Camelbeeck T, Bernard A, Surono (2014) Stress and mass changes at a 'wet' volcano: example during the 2011-2012 volcanic unrest at Kawah Ijen volcano (Indonesia), submitted to J Geophys. Res.

Chouet B (1992) A seismic model for the source of longperiod events and harmonic tremor. In: Volcanic seismology, IAVCEI Proceedings in Volcanology vol. 3. Springer, Berlin, pp 133-156

Chouet BA (1996) Long-period volcano seismicity: its source and use in eruption forecasting. Nature 380(6572):309-316

Chouet BA, Matoza RS (2013) A multi-decadal view of seismic methods for detecting precursors of magma movement and eruption, vol 252, pp 108-175. doi:10.1016/j.jvolgeores.2012.11.013

Clements B, Hall R, Smyth HR, Cottam MA (2009) Thrusting of a volcanic arc: a new structural model for Java. Pet Geosci 15(2):159174

Darwis A (1957) Pandangan dari Kawah Ijen dan sekelilingnja. Tech. rep., Bandung

Delmelle P, Bernard A (1994) Geochemistry, mineralogy, and chemical modeling of the acid crater lake of Kawah Ijen Volcano, Indonesia. Geochim. Cosmochi Ac 58(11):2445-2460

Delmelle P, Bernard A (2000) Downstream composition changes of acidic volcanic waters discharged into the Banyupahit stream, Ijen caldera, Indonesia. J Volcanol Geoth Res 97(1-4): $55-75$

Delmelle P, Bernard A, Kusakabe M, Fischer TP, Takano B (2000) Geochemistry of the magmatic-hydrothermal system of Kawah Ijen volcano, East Java, Indonesia. J Volcanol Geoth Res 97(14):31-53

Djajawinangoen A (1957) Laporan Kawah Idjen dalam bulan agustus/september 1957. Tech. rep., Bandung

Djoharman L (1971) Kawah Idjen dan daerah bahajanja. Tech. rep., Bandung

Green DN, Neuberg J (2006) Waveform classification of volcanic low-frequency earthquake swarms and its implication at Soufrière Hills Volcano, Montserrat. J Volcanol Geoth Res 153(1-2):51-63. doi:10.1016/j.jvolgeores.2005.08.003

Handley HK, Macpherson CG, Davidson JP, Berlo K, Lowry D (2007) Constraining fluid and sediment contributions to subductionrelated magmatism in Indonesia: Ijen Volcanic Complex. J Petrol 48(6): 1155-1183

Harrington RM, Brodsky EE (2007) Volcanic hybrid earthquakes that are brittle-failure events. Geophys Res Lett 34(6). doi:10.1029/2006GL028714

Hartmann E (1917) Geological investigation of the recent damage in the sluice of Kawah Ijen. Tech. rep., Bandung

Hengeveld GJN (1920) De mogelijkheid en de plaats van den bouw van een nieuwe sluis bij het kratermeer Kawah Idjen. Mededelingen en rapporten van het departement der burgelijke openbare werken; Geologische onderzoekingen ten behoeve van 's lands waterstaat-, gewestelijke- en gemeentewerken in NederlandschIndie, Weltevreden pp 93-118

Horsfield T (1814) Reis naar de oosterstreken van Java. In: Verhandelingen van het Koninklijk Bataviaasch Genootschap der Kunsten en Wetenschappen, 7, section 4

Horsfield $\mathrm{T}$ (1816) On the mineralogy of Java. In: Verhandelingen van het Koninklijk Bataviaasch Genootschap der Kunsten en Wetenschappen, 8, section 5, pp 141-173

Hunter JD (2007) Matplotlib: a 2D graphics environment. Comput. Sci. Eng. 9:90-95

Iwamura K, Kaneshima S (2005) Numerical simulation of the steamwater flow instability as a mechanism of long-period ground vibrations at geothermal areas. Geophys J Int 163(2):833-851. doi:10.1111/j.1365-246X.2005.02749.x

Johnson JB, Lees JM, Gerst A, Sahagian D, Varley N (2008) Longperiod earthquakes and co-eruptive dome inflation seen with particle image velocimetry. Nature 456(7220):377-381

Junghuhn F (1853) In: van Kampen PN (ed) Java, deszelfs gedaante, bekleeding en inwendinge structuur, vol 1-4, Amsterdam

Kedar S, Sturtevant B, Kanamori H (1996) The origin of harmonic tremor at Old Faithful geyser. Nature 379:708-711. doi: $10.1038 / 379708 \mathrm{a} 0$ 
Kemmerling GLL (1919) Vulkanische verschijnselen en aardbevingen in den Oost-Indischen Archipel waargenomen gedurende het jaar 1917. Ntvni

Kemmerling GLL (1921) Het Idjen Hoogland de geologie en geomorphologie van den Idjen. de Koninklijke Natuurkundige Vereniging, Batavia

Kim W, Yeh S-W, Kim J-H, Kug J-S, Kwon M (2011) The unique 2009-2010 El Niño event: A fast phase transition of warm pool El Niño to La Niña. Geophys Res Lett 38(15). doi:10.1029/2011GL048521

Konstantinou K, Schlindwein V (2003) Nature, wavefield properties and source mechanism of volcanic tremor: a review. J Volcanol Geoth Res 119(1-4):161-187

Kumagai H, Chouet BA, Nakano M (2002) Temporal evolution of a hydrothermal system in Kusatsu-Shirane Volcano, Japan, inferred from the complex frequencies of long-period events. J Geophys Res 107(B10). doi:10.1029/2001JB000653

Kusnadi I, Surono S, Zaennudin, Kusma, Ilyas M, Yulius O, Rahmanto (2000) Evaluasi Kegiatan G. Ijen, Kabupaten Banyuwangi, Propinsi Jawa Timur. Tech. rep., Bandung

Lahr JC, Chouet BA, Stephens CD, Power JA, Page RA (1994) Earthquake classification, location, and error analysis in a volcanic environment: implications for the magmatic system of the 19891990 eruptions at Redoubt Volcano, Alaska. J Volcanol Geoth Res 62(1):137-151

Lesage P (2009) Interactive Matlab software for the analysis of seismic volcanic signals. Comput Geosci 35(10):2137-2144. doi:10.1016/j.cageo.2009.01.010

Mauri G (2009) Multi-scale analysis of multiparameter geophysical and geochemical data from active volcanic systems. $\mathrm{PhD}$ thesis, Dept. of Earth Sciences-Simon Fraser University, p 468

McNutt SR (2005) Volcano seismology. Ann Rev Earth Planet Sci 33(1):461-491. doi:10.1146/annurev.earth.33.092203.122459

Minakami T (1974) Seismology of volcanoes in Japan. In: Civetta L, Gasparini P, Luongo G, Rapolla A (eds). Elsevier, Amsterdam, pp 1-27

Mueller C (1957a) Idjen crater lake project East Java Republik of Indonesia. Tech. rep., Bandung

Mueller C (1957b) Report of progress, Idjen crater lake project. Tech. rep., Bandung

Neuberg J., Baptie B., Luckett R, Stewart R (1998) Results from the broadband seismic network on Montserrat. Geophys Res Lett 25(19):3661-3664

Newhall CG, Dzurisin D (1988) Historical unrest at large calderas of the world. Tech. Rep. 1855, US. Geol Surv Bull

Oudgast (1820) Mengelingen. In: Bataviaasche Courant

Neumann van Padang M (1983) History of the volcanology in the former Netherlands East Indies. Scripta Geol. 71. Holland, Leiden

Palmer SJ, van Hinsberg VJ, McKenzie JM, Yee S (2011) Characterization of acid river dilution and associated trace element behavior through hydrogeochemical modeling: A case study of the Banyu Pahit River in East Java, Indonesia. Appl Geochem 26: 1802-1810

Pengembangan T (2002) Kajian Perubahan Permukaan air danau Kawah Ijen ditinjau dari segi hidrogeologi. Tech. rep. Yogyakarta, Indonesia

Purwanto B (1999) Pengamatan dan penelitian kegempaan gunungapi Kawah Ijen. Tech. rep., CVGHM, Tamansari, Banyuwangi Regency, Pengamatan dan penelitian kegempaan

Purwanto B (2004) Pengamatan dan penelitian kegempaan gunungapi Kawah Ijen. Tech. rep., CVGHM, Tamansari, Banyuwangi, Regency, Indonesia
Raffles T (1817) The history of Java, Volume two. In: Black, Parbury, Allen (eds) The history of Java, Hon. East India Company 1817 reprinted by Cambridge University Press, 25 Nov, 2010

Reinwardt G (1858) Reis naar het oostelijk gedeelte van den Indischen Archipel in het jaar 1821

Roman DC, Cashman KV (2006) The origin of volcano-tectonic earthquake swarms. Geology 34(6):457-460. doi:10.1130/G22269.1

Scher S, Williams-Jones AE, Williams-Jones G (2013) Fumarolic activity, acid-sulfate alteration, and high sulfidation epithermal precious metal mineralization in the crater of kawah ijen volcano, Java, Indonesia 108(5):1099-1118. doi:10.2113/econgeo.108.5.1099

Sitorus K (1990) Volcanic stratigraphy and geochemistry of the Idjen Caldera Complex, East-Java, Indonesia. PhD thesis, Victoria University of Wellington, New Zealand

Smyth H, Hall R, Hamilton J, Kinny P (2005) East Java: Cenozoic basins, volcanoes and ancient basement. In: Proceedings, Indonesian Petroleum Association, Thirtieth Annual Convention \& Exhibition

Soetardjo M, Untang E, Arnold R, Soetadi S, Ismail, Kertapati E (1985) SEASEE Series on Seismology, Vol. V -Indonesia. Tech. rep., Southeast Asia Association of Seismology and Earthquake Engineering and U.S. Geological Survey

Sriwana T, Kadarsetia K, Saptari D, Sutisna (1999) Laporan evaluasi kegiatan G. Ijen menggunakan parameter kimia serta aspek polusi air kawah pada sungai Banyupahit di kabupaten Banyuwangi Jawa Timur. Tech. rep., Bandung, Indonesia

Stehn CE (1938) Jaarverslag van het vulkanologisch onderzoek over het jaar 1938 door den leider. Tech. rep., Bandung, Indonesia

Stehn CE (1939) Jaarverslag van het vulkanologisch onderzoek over het jaar 1939 door den leider. Tech. rep., Bandung

Stöhr (1862) Der Vulkan Idjen in Ost-Java. In: Verhandelingen van het Koninklijk Bataviaasch Genootschap der Kunsten en Wetenschappen, vol 7, pp 30-47

Sukhyar R (1991) Laporan perjalanan ke gunung api Ijen dan Semeru. Tech. rep., Bandung

Sumarti S (1998) Volcanic pollutants in hyperacid river water discharged from Ijen crater lake, East Java, Indonesia. Master's thesis, Utrecht University, 77 pp., Netherlands

Sutawidjaja I, Supartono H (1987) Laporan pengamtan dan pemasangan RTS di G.Ijen. Tech. rep., Bandung

Takano B, Suzuki K, Sugimori K, Ohba T, Fazlullin SM, Bernard A, Sumarti S, Sukhyar R, Hirabayashi M (2004) Bathymetric and geochemical investigation of Kawah Ijen crater lake, East Java, Indonesia. J Volcanol Geoth Res 135(4):299-329

Taverne N (1923) Vulcanologische berichten XXII-XXIX. In: Natuurkd. Tijdschr. Ned. Indie LXXXIII, pp 17-54

Taverne NJM (1924) Vulcanologische berichten XXII-XXIX. In: Natuurkd. Tijdschr. Ned. Indie LXXXIV, pp 16-86

Leschenault (de la Tour) J (1858) Notice sur un lac d'acide sulfurique qui se trouve au fond d'un volcan du Mont-Idienne, situé dans la province de Bagnia-Vangni, côté orientale de l'ile de Java. Am Mus Hist Nat 18:425-446

Trunk L (2008) Investigating crater lake warming using ASTER thermal imagery. Case studies at Ruapehu, Poas, Kawah Ijen, and Copahue Volcanoes, vol 178, pp 259-270

van Bemmelen R (1941) The Idjen volcano - Precautionary measures against its volcanical menaces. Tech. Rep. 2, Bandung

Van Gelder J, Caron M (1915) Jaarboek van het mijnwezen in Nederlandsch Oost-Indie. Verhandelingen. Tweede gedeelte. Tech. rep., Bandung

Van Hinsberg V, Palmer S, King J, Williams-Jones G, Susanto G, Nasution A (2009) Visual, geochemical, and geophysical observations during mid-2008, vol 34. doi:10.1029/2004GL022284 
Van Hinsberg V, Berlo K, van Bergen M, Williams-Jones A (2010a)

Extreme alteration by hyperacidic brines at Kawah Ijen volcano, East Java, Indonesia: I. Textural and mineralogical imprint, vol 198, pp 253-263. doi:10.1029/2012GC004192

Van Hinsberg V, Berlo K, Sumarti S, Van Bergen M, Williams-Jones A (2010b) Extreme alteration by hyperacidic brines at Kawah Ijen volcano, East Java, Indonesia: II. Metasomatic imprint and element fluxes, vol 196, pp 169-184

Verbeek R, Fennema R (1896) Geologische beschrijving van Java en Madoera. J.G. Stemler, Amsterdam
VSI (1981) Bulletin of the Volcanological Survey of Indonesia for the years 1961, 1962, 1963. Tech. rep., Bandung

Wahyudin D, Wildan A, Mulyadi D, Solichin A (1993) Laporan peningkatan kegiatan vulkanik Kawah Ijen, Jawa Timur. Tech. rep., Bandung

Woudstra H (1920) Analyse van merkwaardige watersoorten op het Idjen-Hoogland. Vol. II, Batavia-Weltevreden, Koninklijke Natuurkundige Vereeniging Monografie, bij G. Kolff and Co., Weltevreden-Batavia 